\title{
El mito de Perseo en los mosaicos romanos. Particularidades hispanas
}

\author{
Guadalupe López Monteagudo *
}

\begin{abstract}
RESUMEN
Análisis iconográfico de las distintas fases del mito de Perseo en los mosaicos romanos, siguiendo las fuentes literarias - Dánae recibiendo la lluvia de oro, llegada de Dánae con el niño Perseo a las costas de Seriphos,

Perseo dando muerte a la medusa volviendo la cabeza al escudo de Athenea, llegada del héroe volando al lugar donde se hallaba expuesta Andrómeda, Perseo vencedor de la medusa $y$ del kethos, Perseo contemplando a Andrómeda encadenada a la roca, el gorgoneion en el centro de un escudo de triángulos curvilíneos o de escamas en alusión a la égida o al escudo de Athenea - y las

creaciones artísticas típicamente romanas - Perseo liberando a Andrómeda y Perseo y Andrómeda contemplando la cabeza de la medusa

en el agua - con especial atención al tratamiento iconográfico y alegórico de los ejemplares hispanos.
\end{abstract}

\section{ABSTRACT}

lconographical analysis of the Perseus' myth related on the roman mosaics, through the literary sources - Danae and the golden rain, Danae and Perseus arriving at Seriphos' coast, Perseus cutting de Medusa's head and turning back his head toward Athenea's shield, Perseus' arrival flying on the site where Andromeda is exposed against the rock, the hero holding the gorgoneion in the raised hand over kethos, the mude contemplation of the girl's beauty, Gorgon's head at centre of shield of lozenges or imbrication pattern - and the original figured representations created by roman ant Perseus helps Andromeda step down from the cliff where she was chained and the two lovers seatted on a rock with the gorgoneion held overhead to reflect in the water - with a special emphasis in the iconographical variations and symbolic significance of the spanish patterns.

* csic. 
En la mitología clásica Perseo ocupa un lugar importante entre los héroes que, a través de sus dilatados viajes en espacio y tiempo, llevan a cabo hazañas beneficiosas para la humanidad, superando numerosos peligros con la ayuda siempre de los dioses y obteniendo, así, la inmortalidad. De esta forma, el personaje mítico, aureolado por sus empresas victoriosas pasa a integrarse, por su carácter alegórico de imagen benéfica, en los programas iconográficos de los lugares, en los que se representa, con un acusado simbolismo en relación a ideas de bienestar y de prosperidad.

La historia de Perseo no comporta tantas hazañas como en el caso de otros personajes legendarios, y a pesar de todo ocupa en los mitos de la Argólida el mismo lugar que Teseo en los del Atica. Incluso puede decirse que sus empresas se concretan en una sola, la decapitación de la Medusa, pero la hazaña es de tal entidad que, a partir de ahí, el héroe puede emprender otras acciones secundarias y volver triunfante a su patria. Este episodio se localiza en el extremo Occidente (Aischyl. prom. 791), no lejos de las Hespérides (Hes. theog. 213-216, 274-276), del reino de los muertos, de los Geriones, en el Norte, cerca de los Hiperbóreos (Pind. pyth. 10, 31-50; en 10, 72 habla de Libia, Etiopía o Eritrea), o en Libia (Hdt. II 91; Lucan. phars. IX 619 ss.; Lucian. dial. mar. 14, 2; Diod. III, 52,4), en definitiva, en un lugar remoto para la mentalidad de la época, al que Perseo llega volando sobre el Océano, donde se hallaba la cueva en la que dormian las Gorgonas. También en el más allá del mundo conocido se localizan las otras hazañas del héroe argivo, de modo que puede decirse que hay una secuencia narrativa y también discursiva entre las fases del mito, una concatenación de los hechos que al héroe le ocurren en el extremo Occidente ${ }^{1}$.

Según el relato mitológico Perseo es el fruto de los amores adúlteros de Júpiter con Dánae, la hija del rey legendario de Argos, Akrisios, a quien el oráculo de Delfos había augurado que el hijo de su única hija, Dánae, sería el causante de su muerte. Para impedir que se cumpliera la predicción del oráculo, Akrisios encerró a Dánae en una cámara subterránea de bronce o en una torre, fuertemente custodiada, en donde fué poseida por Zeus mediante la lluvia de oro que el dios hizo penetrar por una grieta del techo. Cuando Akrisios se enteró del nacimiento de su nieto y no creyendo en su origen divino, le arrojó al mar junto a su madre

G. López Monteagudo, Perseo, viajero a Occidente. Documentos musivos, XIII Convegno di studio su l'Atrica Romana (Djerba, Tunis-1998), en prensa. Sobre la localización de los mitos griegos en el límite occidental del mundo, cf. J.C. BERMEJo, Mitología y mito de la Hispania prerromana, Madrid 1982; J.M. BlAzouez, Gerión y otros mitos griegos en Occidente, Gerión 1, 1983, págs. 21-38. 
Dánae en un cofre de madera, que empujado por los vientos llegó a las Cícladas, siendo recogidos en la isla de Seriphos por Diktys, hermano del rey Polydektes (Hom. II. 14, 319-320; Ps. Hes. ehoiai fr. 129; Pind. pyth. 10, 44-48; Soph. Ant. 944-950). Perseo fué educado por los sacerdotes del templo de Athenea. Pasados unos años y ante la insistencia de Polidektes de desposar a Dánae contra su voluntad, el joven prometió al rey traerle la cabeza de la Medusa, la mortal de las tres Gorgonas, a cambio de que dejara de importunar a su madre. Athenea y Hermes acudieron en ayuda de Perseo enviándole a las Grayas o Fócides, las tres "viejas" hijas monstruosas del dios marino Forcis, que habitaban en el extremo occidente, en el país de la noche donde nunca luce el sol y eran las encargadas de cerrar el camino que conducia hacia sus hermanas las Gorgonas, tenían entre las tres un solo ojo y un solo diente, quienes le dijeron cómo llegar a las Ninfas. Estas proporcionaron al héroe el equipo mágico para matar a la Medusa, la kibisis, bolsa donde habría de guardar la cabeza cortada de la Medusa, las sandalias aladas para huir de las Gorgonas y el gorro de Hades que le hacía invisible; Hermes le dio la harpé, cuchilla de diamante para cortar la cabeza de Medusa, y Athenea el escudo pulido para reflejar la imagen de la Gorgona, ya que Perseo debía volver la cabeza para no mirarla directamente so pena de quedar petrificado (Apollod. bibl. II, 4,2; Ov. met. IV, 782-5; Nonn. dion. 25,35. 31,15; Lucan. phars. IX 669 ss.).

Una vez hubo cortado la cabeza de la Medusa, de cuyo cuello surgieron Pegaso y Crisaor, Perseo huyó de las otras dos Gorgonas, que le perseguían, montado sobre Pegaso y volviéndose invisible gracias al casco que le había dado Hades. Al caer la noche, el héroe decidió descansar en Mauritania, para lo que solicitó la hospitalidad de su rey, Atlante, que vivía en las extremidades del mundo, en el país donde el sol se pone. Aquí, en la inmediaciones del monte Atlas, aunque otros mitógrafos lo ubican al oeste de Libia y también en el país de los Hiporbóreos, se encontraba el jardín en el que Hera había ordenédo plantar las famosas manzanas de oro, regalo nupcial de Gea cuando la diosa se desposó con Zeus, custodiadas por las Hespérides, cuyos nombres - Egle, la «resplandeciente», Eritia, la «roja» y Hesperaretusa, la «Aretusa de Poniente»- aluden a los matices del cielo cuando el sol va hacia el ocaso, es decir, hacia el extremo occidente (Hes. theog. 215 ss.; Diod. III 60; Serv. ad Aen. IV 438; VIII 134). Atlante, recordando la profecía de un oráculo de Temis, según la cual un hijo de Zeus llegaría para apoderarse de las manzanas de oro, le negó la hospitalidad, por lo cual Perseo le petrificó al mostrarle la cabeza de la Medusa, quedando convertido en la montaña que lleva su nombre y que ya Herodoto (IV 184) sitúa en el Africa septentrio- 
nal ${ }^{2}$. Este episodio de la metamorfosis de Atlas en montaña solo lo relata Ovidio (met. IV 639 ss.) y más tarde lo recogen Lucano (phars. IX 654 ss.) y Servio (ad Aen. IV 246), por lo que parece que se trata de un culto local.

A continuación, Perseo pasó sobre su caballo alado por Etiopía, según algunos mitógrafos (Eratosth. cat. XXII 15-17; Antiphilos, anth. pal. XVI 147; Hyg. astr. 4, 2,9; Apollod. bibl. II, 4, 3-5; Ov. met. IV, 669, 764; Libanius, narrationes 35-36; Philostr. imag. I, 29), lugar que según Eurípides (TGF frg. 145) se halla con certeza en el Atlántico, donde, tras matar al kethos que la custodiaba, liberó a Andrómeda, que se hallaba encadenada a una roca espiando las palabras proferidas por su madre Cassiopea de ser la más bella de las nereidas (Apollod. bibl. II, 4,3, 2-6; Tzetz. Lycophr. 836-839; Prop. 3. 22,29; Ov. met. IV 663 ss.). Perseo, enamorado de Andrómeda, había obtenido de Kepheo, rey de los etiopes, la mano de la joven a cambio de matar al monstruo, compitiendo de esta forma con Phineus, el hermano de aquel a quien también se la habia prometido en matrimonio y que le urde un complot. Perseo muestra a Phineus y a sus cómplices la cabeza de la Medusa convirtiéndoles en piedras (Ov. met. V 3,180, 216).

Después de realizar estas hazañas y de vengarse de Polidektes convirtiéndole asimismo en piedra, Perseo entregó el trono de Seriphos a Diktis y devolvió las sandalias, la bolsa y el casco a Hermes, mientras ofrecía la cabeza de Medusa a Athenea que la colocó en la égida (Hom. II. V 738742; Eur. Ion 987-999; FHGI, fr. 26; Diod. III 70,5; Paus. IX 442-444; Sil. IX 442-444; Lucan. phars. IX 655-658; Erastosth. cat. XXII 20-25; Ov. met. IV 791-803) o en su escudo (Eur. el. 1255-1257; Apollod. bibl. II 46; Claud. cons. Stil. 24.128). En el regreso a su patria, Perseo causó accidentalmente la muerte de su abuelo Akrisios, cumpliéndose de esta forma la predicción del oráculo. $Y$ puesto que la tradición impedía a un homicida ocupar el trono de Argos, se lo cambió a su primo Megapentes por Tirinto, atribuyéndosele también la fortificación de Midea y Micenas (Apollod. bibl. II, 4,4 ; Paus. II 15,4; 16,3).

Las distintas secuencias del mito de Perseo, desde su concepción y llegada a la isla de Seriphos, su triunfo sobre la Medusa y el kethos y finalmente su regreso con Andrómeda, fueron plasmadas en el arte antiguo con bastante frecuencia. Sin embargo, el episodio de la muerte de la Medusa fué el más importante del legendario relato y el preferido por los artistas de época arcáica, incluyéndose la presencia de Athenea a partir

2 J. Dessanges, Recherches sur l'activité des Méditeranéennes aux confins de l'Afrique, Roma 1978 
de época clásica por deseo de los atenienses, que deseaban realzar el papel de su diosa haciéndola intervenir de manera activa en las hazañas del héroe, bien tomando su lugar en el combate o ayudándole a ver la cabeza de la Medusa reflejada en el agua o en su escudo. Posteriormente, el mito de Perseo gozó de tanto favor entre los romanos, quienes consideraban la figura del héroe como un talismán contra las influencias malignas, lo mismo que la cabeza de la Medusa, que hicieron llegar el cofre, en el que iban encerrados Dánae y su hijo Perseo, a las costas del Lacio, donde Dánae se casó con Pilumno y fundó la ciudad de Ardea, siendo Turno, rey de los rútulos, uno de sus descendientes (Vergil. Aen. VII 410; Serv. ad Aen. VII 372). Otra tradición cuenta que Dánae llegó a Italia con sus hijos Argo y Argeo, estableciéndose en el lugar de la futura Roma. De esta forma, el relato mítico de Perseo se convierte, al igual que otros muchos, en un mito de carácter etiológico.

La musivaria romana ha proporcionado varios ejemplos del primer episodio del mito, el del momento de la seducción de Dánae por Zeus, transformado en lluvia de oro, por lo general formando parte de un conjunto en los que figuran otros amores de Júpiter, en especial Leda y el cisne, Europa y el toro, Ganímedes y el águila, sátiro y Antiope, con una amplia cronología que va del siglo $\|$ al IV. En todos ellos Dánae aparece de pie o sentada, recibiendo en su mano o en su manto la lluvia de oro que cae de lo alto desde una nube en la que se encuentra una vasija o más raramente el propio Júpiter.

Este momento de la seducción de Dánae por Zeus, transformado en lluvia de oro, solo se representó en la musivaria hispano-romana en el pavimento de los Amores de Júpiter, procedente de Itálica (Sevilla), que se conserva en la colección de la Condesa de Lebrija, y se data en la segunda mitad del siglo $\|$ d. $C^{3}$ (Fig. 1). La superficie del pavimento, que forma prácticamente un cuadrado, ostenta un esquema compositivo de cuadriculado de círculos grandes y pequeños tangentes, nueve grandes y ocho pequeños, en lacería de trenza de dos cabos, que determinan cuatro octógonos irregulares cóncavos. El medallón central se ha decorado con un busto masculino tocando la siringa, identificado probablemente con Argos y también con Pan, Apolo o Polifemo, mientras que las Estaciones ocupan los cuatro medallones de los ángulos. Los cuatro rondos restantes, situados en el centro de los lados, van ocupados por escenas mitológicas sacadas del ciclo de los amores de Júpiter: Leda y el cisne, Ganímedes ofreciendo el contenido de una pátera al águila de Zeus, Dánae recibiendo la lluvia de 


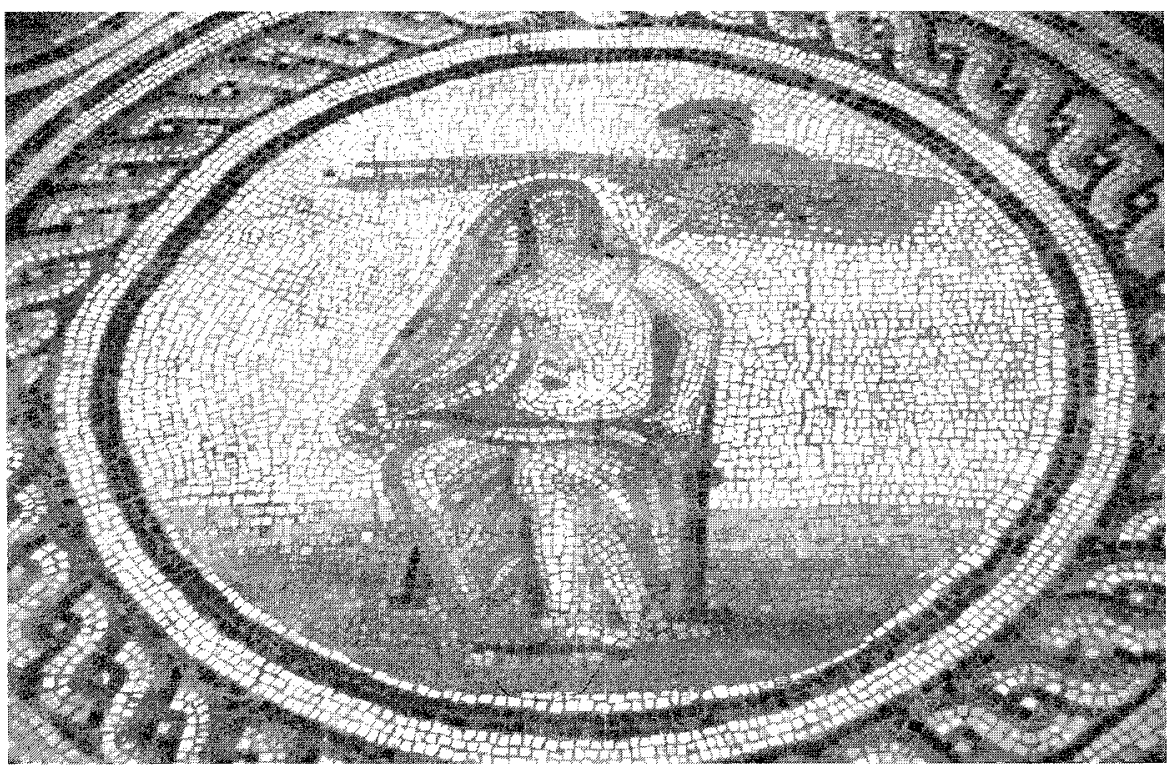

Figura 1. Dánae recibiendo la lluvia de oro. Mosaico de Itálica. Foto G. López Monteagudo.

oro y finalmente la vaca lo con la media luna marcada en su vientre. Los octógonos centrales ofrecen otros temas del repertorio de los Amores de Júpiter: Europa y el toro, Arcas y Calisto metamorfoseada en osa, sátiro persiguiendo a Antiope; el cuarto va decorado con la imagen alegórica del río Asopos, cuya hija Egina fué raptada por Zeus ${ }^{4}$. El cuadro que nos interesa hace alusión a la concepción de Perseo y, por consiguiente, ilustra el primer momento del mito, cuando Dánae recibe la lluvia de oro que le envía Júpiter, desbaratando de esta forma las precauciones tomadas por su padre de encerrarla en una gruta a la que nadie podía tener acceso. Dánae aparece sentada de tres cuartos, en un sillón, del que se ve parte del respaldo y de las patas delanteras; el himation cubre la cabeza y es sostenido con ambas manos por encima de las piernas, dejando ver la desnudez del resto del cuerpo, lo que acentúa el alto erotismo de la escena. La joven levanta la cabeza hacia la nube situada en la parte superior izquierda del medallón, de la que sale la caioza de Júpiter. Esta iconografía de Dánae sentada en una silla o recostada en una kliné, remonta a los vasos beocios

4 Cf. G. López Monteagudo-M.P. San Nicolás Pedraz, El mito de Europa en los mosaicos hispano-romanos. Análisis iconográfico e interpretativo, Espacio, Tiempo y Forma II/8, 1995, págs. 391-394, fig. 8. 
e italiotas de figuras rojas y, como en ellos, no hay ninguna referencia arquitectónica. A partir del segundo cuarto de siglo v. a.C. Dánae interviene activamente en la escena, levantando con ambas manos su vestimenta para acoger las gotas de tan preciada lluvia en su regazo desnudo, haciendo referencia, de esta forma, al momento mismo de la concepción.

Los paralelos iconográficos más próximos para el ejemplar hispano se documentan en los pavimentos del Beyrouth y de Cartago, ambos, sin embargo, con una cronología bastante más tardía que el mosaico de Itálica, ya que se fechan a comienzos del siglo IV. En la escena libanesa, de ca. 300

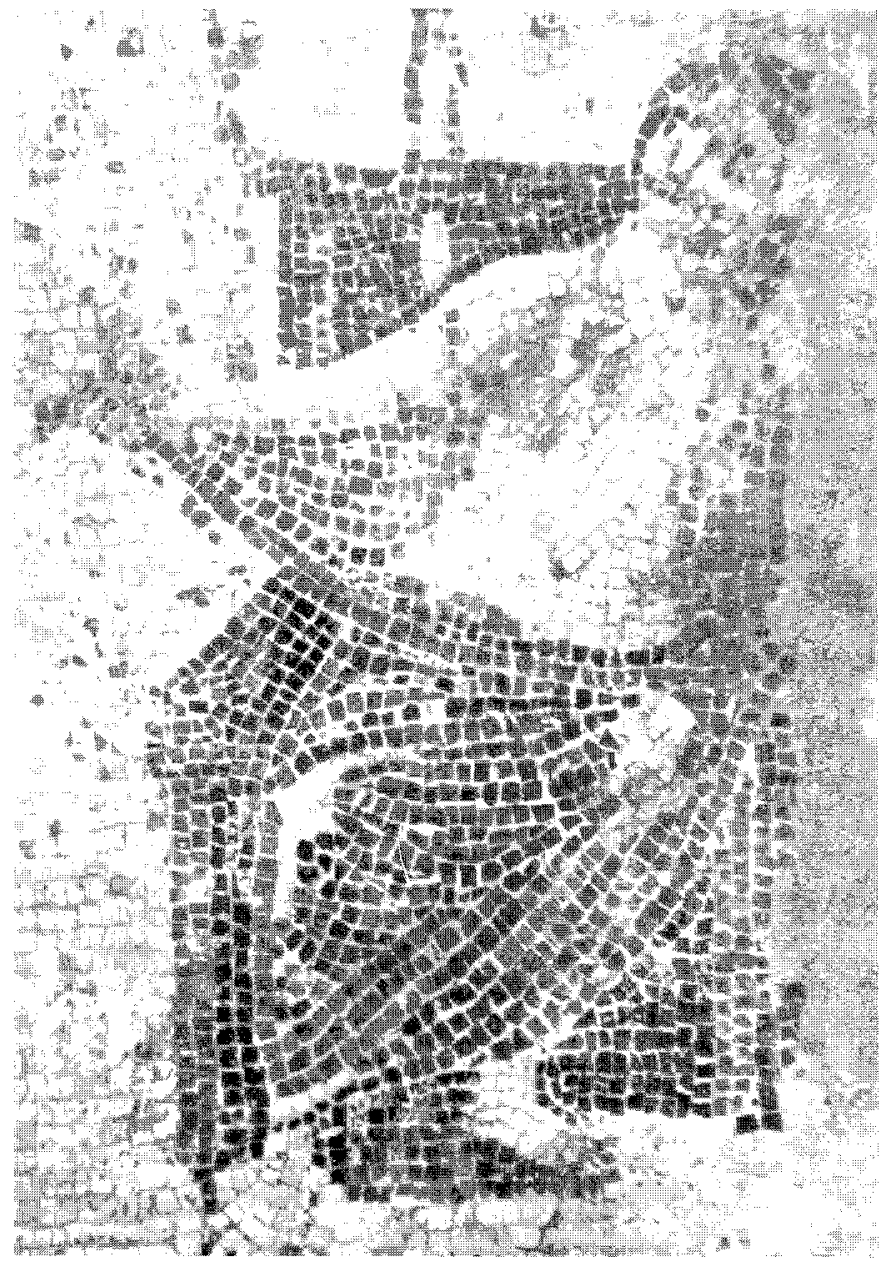

Figura 2. Dánae recibiendo la lluvia de oro. Mosaico de Beyrouth. 
d.C., se representó a Dánae recibiendo la lluvia de oro junto a los grupos formados por sátiro y Antiope, Leda y el cisne, Ganimedes y el águila 5 (Fig. 2). Dánae se ha figurado, como en Itálica, sentada de frente en un sillón de alto respaldo recto; va vestida con himation que cubre la parte inferior del cuerpo y deja ver el torso desnudo; la joven aparece reclinada hacia la derecha y con la mirada levantada a la izquierda, despegando el manto con su brazo derecho extendido para acoger en su regazo la lluvia de oro que cae por detrás en línea recta y no oblicuamente como es usual.

En el pavimento de los caballos procedente de la Casa de los Caballos de Cartago, que se data ca. 300 d.C., el episodio de la seducción de Dánae ocupa uno de los cuadrados junto a otros temas mitológicos como Amazona, Aquiles, Dédalo, Dióscuros, Eteocles y Polynice, Hércules, Hylas, Licurgo, Narciso, Orfeo y Pelops, que, según J. W. Salomonson, aludirian al nombre de los caballos ${ }^{6}$ (Fig. 3). Dánae aparece de pie delante de un caballo de carreras, girada ligeramente hacia su izquierda; lleva el torso

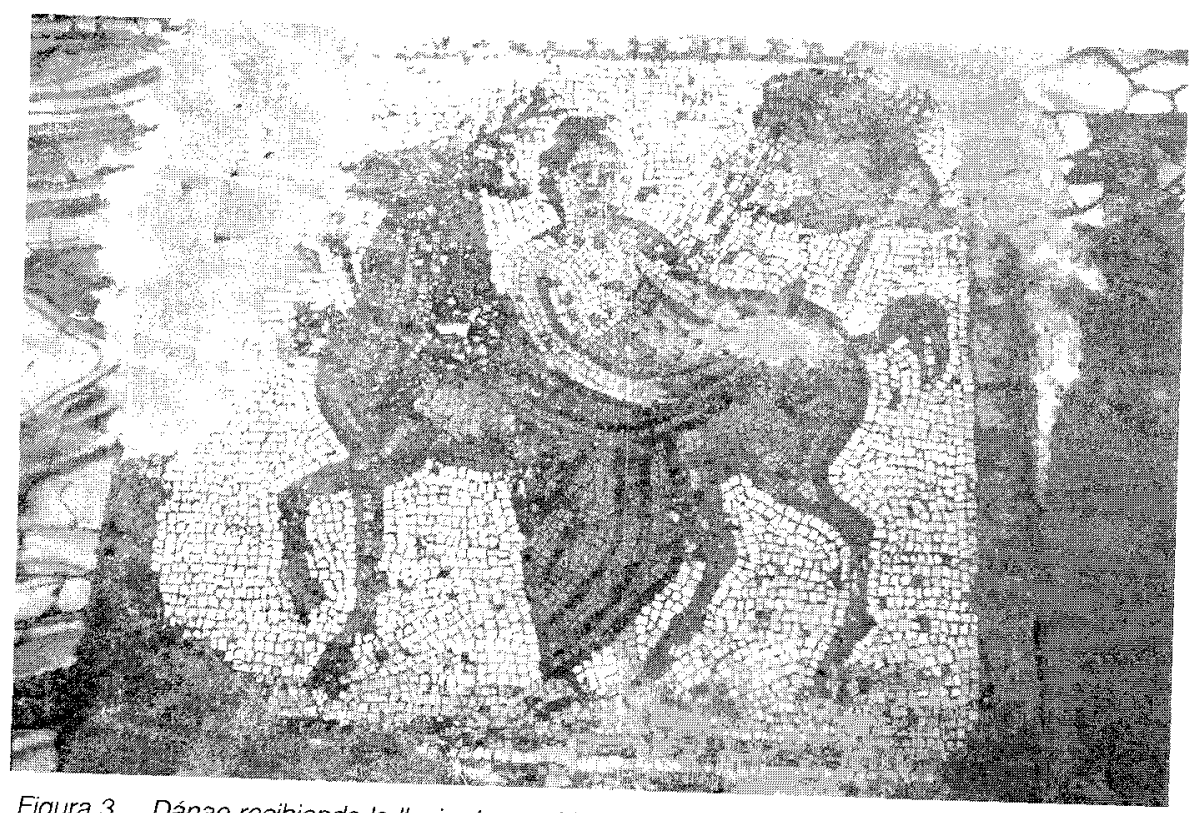

Figura 3. Dánae recibiendo la lluvia de oro. Mosaico de Carthago. Foto G. López Monteagudo.

M. Chehab, Mosaïques du Liban, BullMusBeyrouth 14-15, 1958-59, págs, 21-26, pl. vill y X, 2

6 J.W. Salomonson, La mosaïque aux chevaux de l'Antiquarium, págs, 21-26, pl. Vlll y X, 2. págs. 67 y $120, n^{\circ} 48$, fig. 52, pl XLVIII 3. Según acompañan a los caballos victoriosos podrian 
desnudo y levanta con ambas manos el chiton para recibir la lluvia de oro que sale de la nube situada en la parte superior, en la que, al igual que en el mosaico italicense, también se ha representado el busto de Júpiter.

Estos detalles iconográficos proporcionan a las escenas de Itálica, Beyrouth y Carthago un elevado contenido erótico, ya que la presencia de Júpiter en la nube y la desnudez y actitud de la joven levantando su himation indican no la metamorfosis del dios, que en forma de lluvia de oro penetra en la cueva donde se hallaba encerrada Dánae, sino el momento mismo de la fecundación a través de la lluvia de oro que Júpiter le envía desde lo alto. Los prototipos se encuentran en gemas y lekythoi áticos plásticos de mediados el siglo Iv a.C. (Fig. 4), diferenciándose de otras representaciones musivas con el mismo tema, que siguen el modelo más narrativo de la metamorfosis de Júpiter?

Otro mosaico norteafricano, de comienzos del siglo Iv d.C., en el que se representa a Dánae recibiendo la lluvia de oro es el pavimento de Ouled Agla, que se data probablemente a comienzos del siglo IV ${ }^{8}$ (Fig. 5). En el recuadro rectangular que preside el emblema, el episodio de Dánae figura junto a otros amores de Júpiter: Leda y el cisne, sátiro y Antiope, Ganímedes dando de beber al águila en presencia de Júpiter, Europa y el toro, coincidiendo en esta conjunción con los mosaicos de Itálica, Beyrouth y Palermo. Dánae se ha figurado entre los grupos formados por Ganímedes y Europa, delante de un ara cuadrangular coronada por una vasija; está sentada hacia la izquierda y con el torso, cubierto con chiton e himation, vuelto al lado contrario para recibir en su mano derecha la lluvia que cae de arriba por detrás de su espalda.

En Palermo este primer momento del mito de Perseo se representó en la parte inferior del gran mosaico polícromo de la Piazza della Vittoria, datado en la primera mitad del siglo III, donde pavimentaba la habitación de una casa o una capilla privada destinada a cultos mistéricos dionisiacos ${ }^{9}$ (Fig. 6). La escena de Dánae recitiendo la lluvia de oro, hoy perdida, ocupaba el octógono central de la segunda fila, entre otros dos decorados

a los nombres de los animales, documentados epigráficamente en otros soportes. Así, Danaus, aparece como nombre de caballo en CIL VI 100047 y 100053, ct. págs. 84-89.

7 LIMC III, «Danae», núms. 1-12, 24-26.

8 I. LAVIN, The hunting Mosaics of Antioch and their Sources, DOP 17, 1963, pág. 264, fig. 131; O. WATTEL-De-Crolzant, Les mosaïques représentant le mythe d'Europe (Ier-Vle siècles), Paris 1995, págs. 217-220, pl. XXIX-a

9 R. Camerato-Scovazzo, Nuove proposte sul grande mosaico di Piazza della Vittoria a Palermo, Kokalos 21, 1975, págs. 231-272; D. von Boeselager, Antike Mosaiken in Sizilien, Roma 1983, págs, 175-183, Taf. LXI. 


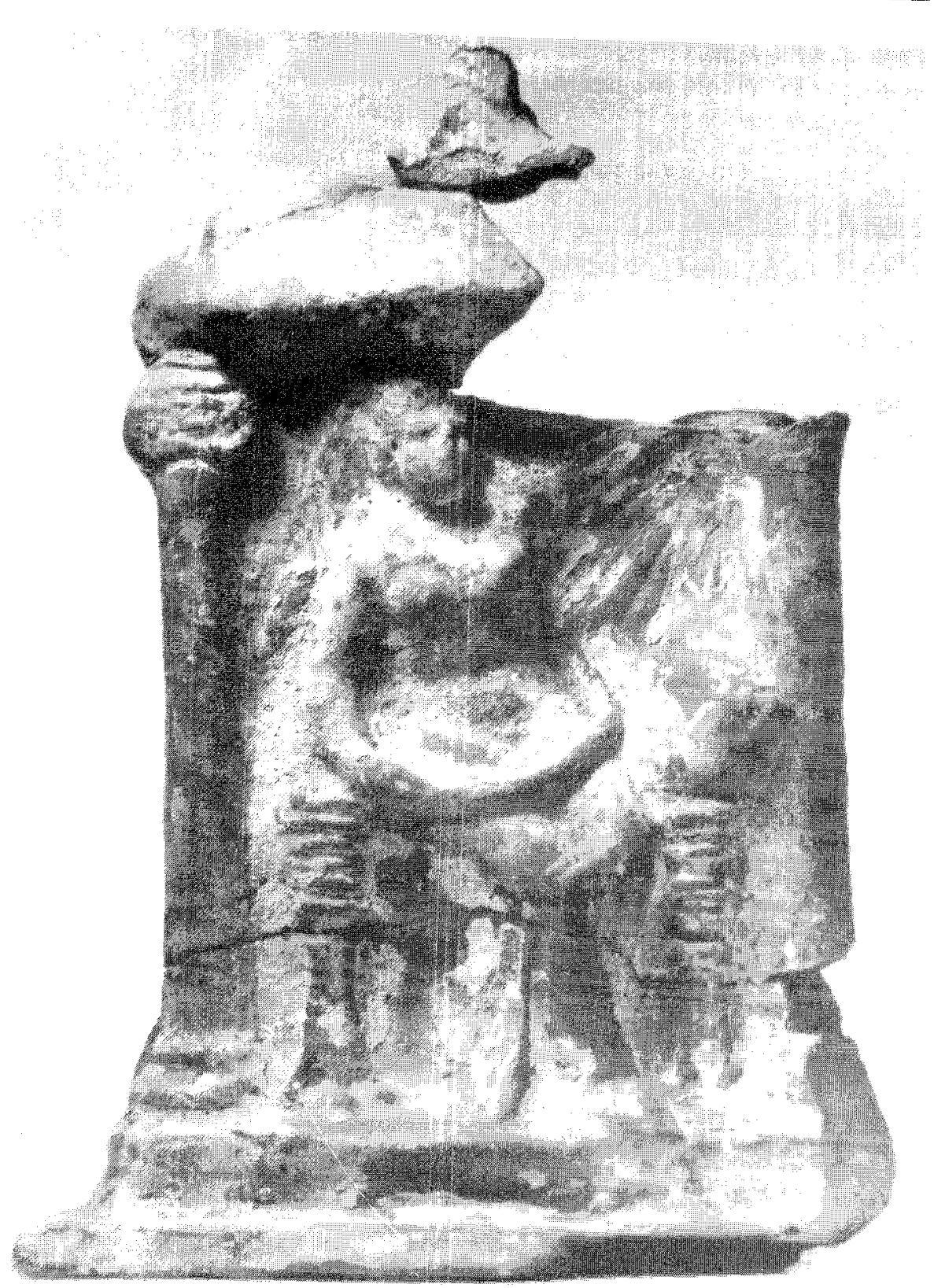

Figura 4. Dánae recibiendo la lluvia de oro. Lekythos plástico ático, Museo de Würzburg. 


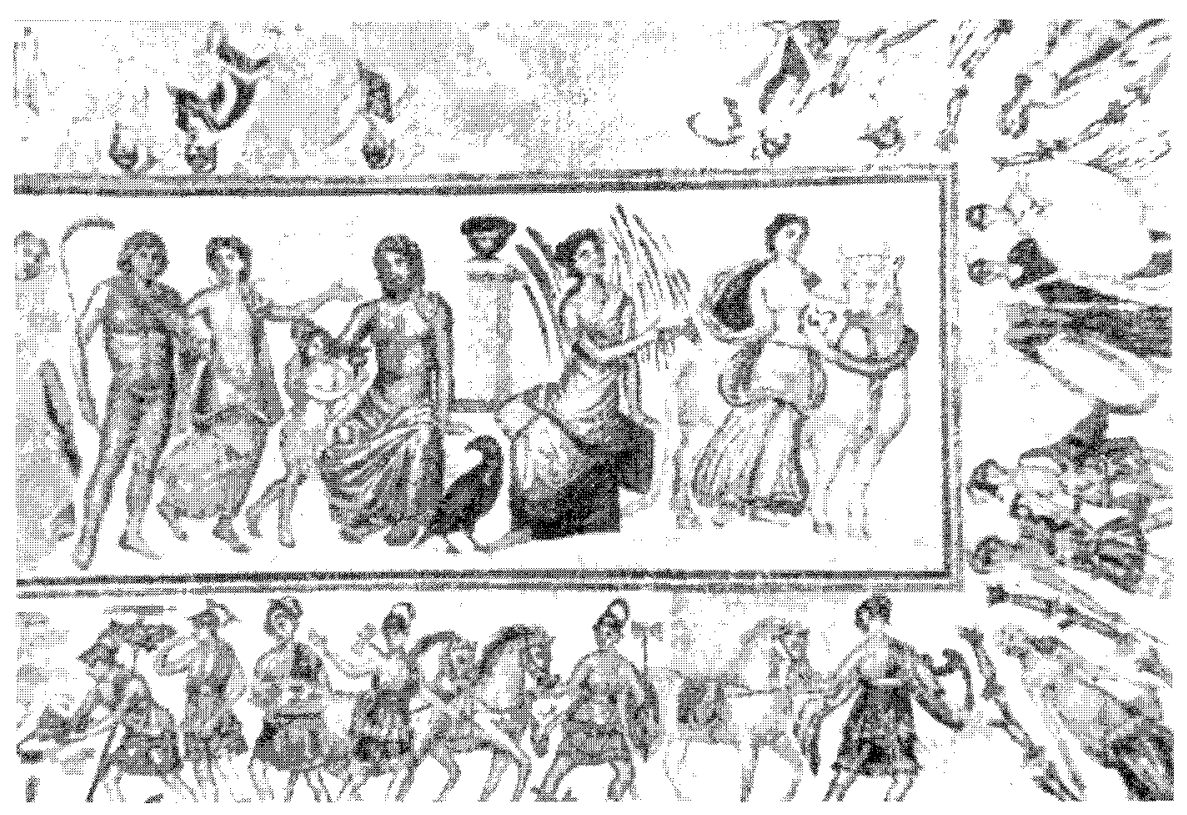

Figura 5. Dánae recibiendo la lluvia de oro. Mosaico de Ouled Agla.

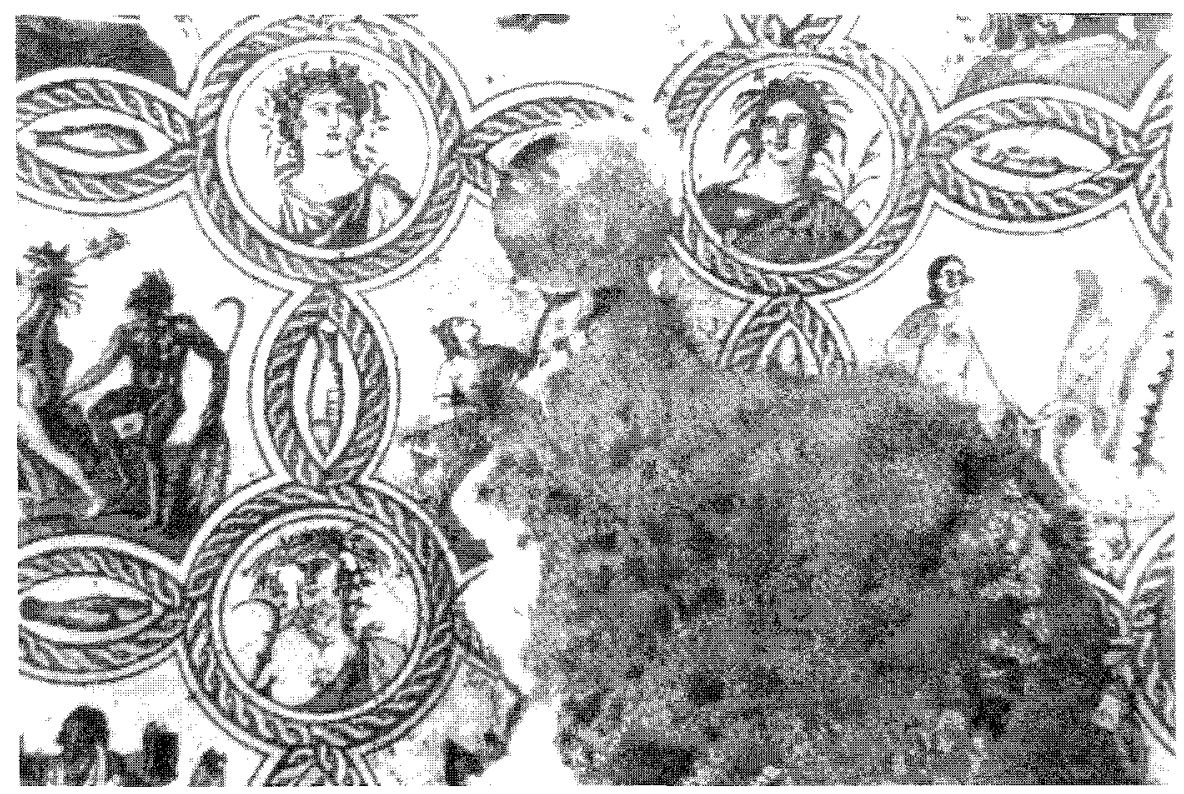

Figura 6. Dánae recibiendo la lluvia de oro. Mosaico de Palermo. 
con sátiro y Antiope, Leda y el cisne y separados de ellos por cuatro medallones circulares con los bustos de las estaciones. Como en el mosaico de Itálica, Dánae aparece sentada hacia la derecha y levantando su mirada para arriba al recipiente de donde sale la lluvia de oro. En la fila inferior se disponen las figuras de tres sabios sentados en sillones de respaldo curvo, mientras que en la superior Helios y Neptuno ocupan los espacios octogonales en torno a la figura de Dionisos sobre el grifo ${ }^{10}$. Otro grupo formado por Europa y el toro destaca del resto de los cuadros decorados con los «Amores de Júpiter», dispuestos en la penúltima fila de la zona terrestre, por ocupar un lugar privilegiado en el Olimpo, en el centro del thiasos marino ${ }^{11}$.

La musivaria romana ha proporcionado otros episodios del mito de Perseo, no documentados por el momento en Hispania. Así, la llegada de Dánae con su hijo Perseo a las costas de Seriphos solo se documenta en el mosaico hexagonal que pavimentaba el frigidarium de las Grandes Termas de Thina, de fines del siglo III, conservado en el Museo de Sfax ${ }^{12}$ (Fig. 7). Dánae aparece saliendo del cofre y sosteniendo en su brazo izquierdo al niño Perseo; lleva himation sobre las caderas, dejando al descubierto su torso desnudo, y velo desplegado sobre la cabeza a la manera del tipo de Europa velificante sua manu ${ }^{13}$; a ambos lados se han figurado, a una escala bastante menor, sendas figuras masculinas, tal vez los pescadores de la isla de Seriphos o Diktys y Polidektes, conservándose solo el personaje de la derecha. El grupo forma parte de una gran escena marina presidida por Arion cabalgando sobre el delfín, en la que se han representado otros temas mitológicos, como Dédalo, Venus en la concha, Scylla, Ulises y las Sirenas, Selene y Endimión, Leandro y Hero, Perseo y Andrómeda o Hércules y Hesión, junto a erotes, nereidas y tritones, aurigas en carros tirados por delfines, monstruos marinos, barcos y pescadores. La llegada de Dánae y Perseo a la isla de Seriphos gozó de gran favor en el arte romano, documentándose varias veces en pinturas de Pompeya, pero, a diferencia del mosaico tunecino, en el que la actitud de

10 G. Lopez Monteagudo, M.P. San Nicolas Pedraz, Reflejos de la vida intelectual en la musivaria romana, Espacio, Tiempo y Forma II/7, 1994, págs. 303-304; ID. Los sabios y la ciencia en los mosaicos romanos, L'Africa Romana XI, 1996, págs. 71-110.

11 O. WATtEL-De Croizant, Les mosä̈ques représentant le mythe d'Europe (ler-Vle siècles), Paris 1995, págs. 126.127.

12 K.M.D. Dunbabin, The Mosaics of Roman North Africa, Oxford 1978, págs. 43, 273 ; R. Massigl, Musée de Sfax, Paris 1912, págs. 4-5, pl. IV,2.

13 G. López Monteagudo, M.P. San Nicolás Pedraz. El mito de Europa en los mosaicos hispano-romanos. Análisis iconográfico e interpretativo, Espacio, Tiempo y Forma Il/8, 1995, págs. 383-438. 


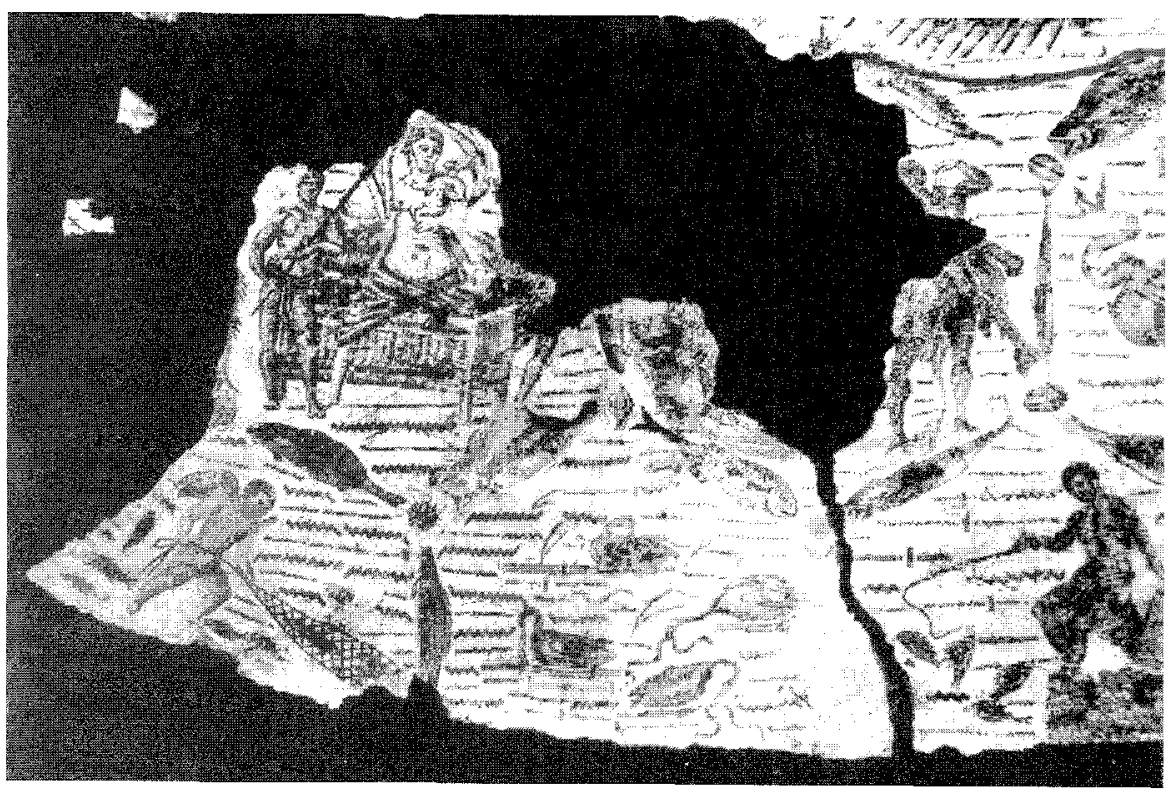

Figura 7. Llegada de Dánae y Perseo a Seriphos. Mosaico de Thina.

movimiento de Dánae imprime un carácter netamente narrativo a la escena, en la pintura pompeyana Dánae aparece siempre sentada con el niño Perseo en su regazo (Fig. 8) ${ }^{14}$.

La acción misma de cortar la cabeza a la Medusa, que tanto éxito tuvo en otros soportes siguiendo prototipos del siglo IV a.C., se figuró solamente una vez en la musivaria romana, en un interesante pavimento descubierto en Esparta, datado en la segunda mitad del siglo III (Fig. 9) ${ }^{15}$. La escena, que ocupa el centro de una composición cuadrangular, figura a Perseo en el momento de cortar con la harpé la cabeza de la Medusa, de la que surge Pegaso, que aparece arrodillada a su izquierda en compañía de sus dos hermanas figuradas mediante dos cabezas en el extremo derecho del cuadro; el héroe vuelve la cabeza hacia el escudo que le tiende la diosa Athenea, situada a su derecha, para no mirar directamente a la Medusa y escapar asi a la fuerza petrificadora de su mirada (Apollod. bibl. II, 4,2; Ov. met. IV, 782-5; Nonn. dion. 25,35.

\footnotetext{
14 LIMC III, «Danae», núms. 61-66.

15 A. Panaglotopoulou, Représentations de la Méduse dans les mosaïques de Grèce, VI CIMA, Guadalajara 1994, págs. 369-382, Fig. 21.
} 


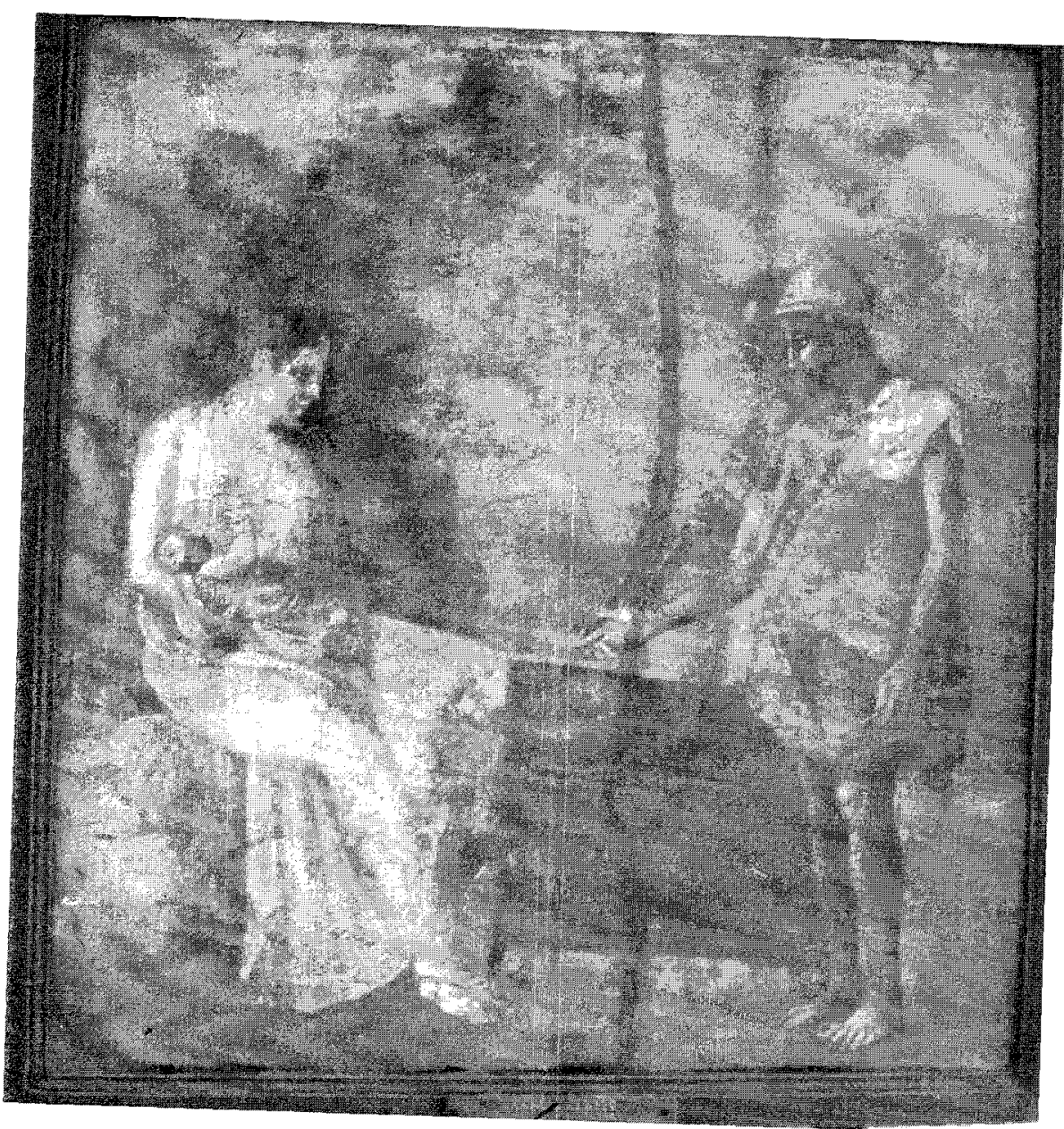

Figura 8. Llegada de Dánae y Perseo a Seriphos. Pintura de Pompeya. Foto G. López Monteagudo.

31,15; Lucan. phars. IX 669 ss.). Todos los personajes van acompañados por sus nombres en griego, destacando por su interés geográfico la incripción Libye que identifica a la figura femenina detrás de la Medusa como la personificación del pais donde, según algunos autores, tiene lugar esta hazaña (Hdt. II, 91; Paus. III 17,3; Diod. III 57,4 y 55,3; Lucan.
phars. IX, 619 ss.).

En la musivaria hispano-romana no se representó este episodio del mito de Perseo, que sorprendentemente se halla documentado, con una 


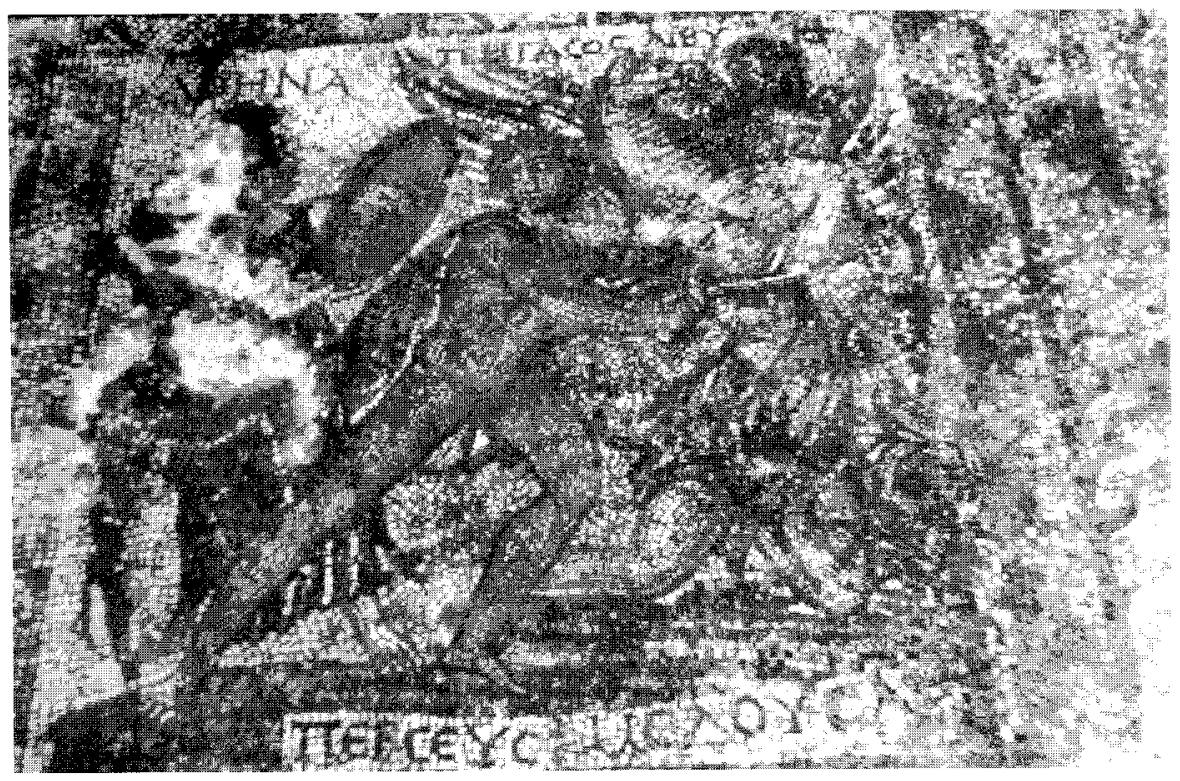

Figura 9. Perseo dando muerte a la Medusa. Mosaico de Esparta.

iconografía casi exacta, en una pátera de plata y oro, fechada en el siglo ॥ d.C., procedente de una sepultura de Lameira Larga (Penamacor, Castelo Branco, Portugal), dada en paradero desconocido durante mucho tiempo, pero que en la actualidad se conserva en el Museo Nacional de Arqueologia e Etnologia de Lisboa (Fig. 10) ${ }^{16}$. La figura de Perseo centra la composición entre Athenea y Hermes; va desnudo, con clámide abrochada sobre el hombro derecho y sostenida en forma de kibisis, con ambas manos por Hermes, que se encuentra situado a su izquierda; lleva gorro frigio y alas en los pies. El héroe se dirige con la harpé hacia la cueva en la que duermen las tres gorgonas, identificándose Medusa por las alas en la cabeza y las serpientes en el cabello y en la vestimenta, al tiempo que vuelve el rostro al escudo que, a modo de espejo, le sostiene la diosa, situada a su derecha. Detrás de Athenea se ha figurado un olivo, en cuya rama se posa la lechuza, símbolo de la diosa. En la parte baja aparece el casco, la funda de la harpé y dos ramas, una de olivo y otra con dos manzanas, haciendo alusión esta última al

16 W. Trillmich et alii, Hispania Antiqua. Denkmäler der Römerzeit, Mainz 1993, págs. 240241, Farbtafel 14; G. Lopez Monteagudo, El triunfo de Perseo sobre la muerte, Hom. a C. Serrano, Madrid, en prensa. 


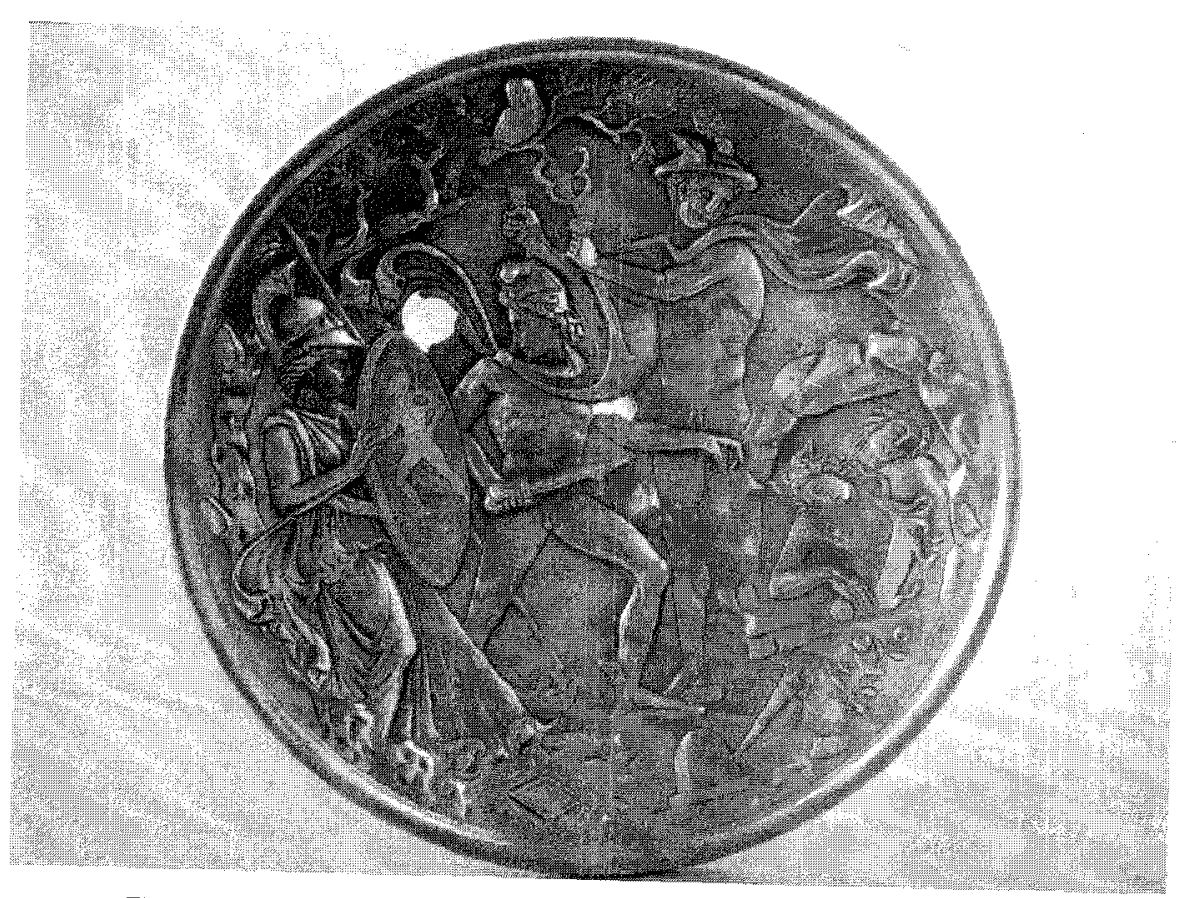

Figura 10. Perseo dando muerte a la Medusa. Pátera de Lameira Larga (Castelo Branco).

lugar del acontecimiento en las proximidades del jardín de las Hespérides, como sostienen ciertas fuentes literarias (Hes. theog. 274-276) e ilustran algunas cerámicas griegas mediante la inclusión en la escena de un árbol ${ }^{17}$.

Aunque esta hazaña se halla bien atestiguada artísticamente desde época temprana, sin embargo ambos documentos iconográficos ofrecen una variante menos frecuente pero de un gran interés iconográfico ya que ilustra un episodio solo conocido desde Píndaro (pyth. 10,48), que es aquel en el que Perseo corta la cabeza de la Gorgona volviendo la suya hacia el escudo que sostiene Athenea, ajustándose fielmente el relato de Luciano (dom. 25; dial. mar. 14, 2, 323), mientras que en Ovidio (met. IV 782-5) y Lucano (phars. IX 669 ss.) es el mismo Perseo

\footnotetext{
K. Schaueneung, Perseus und der Kunst des Altertums, Bonn 1960, págs. 20-21, Tat.
} 
el que sostiene el escudo ${ }^{18}$. El episodio se encuentra representado, siguiendo prototipos del siglo IV a.C., varias veces en el arte romano, siendo el paralelo más próximo un relieve procedente seguramente de Aquincum, de fines del siglo $\|$ d.C, en el que Perseo corta la cabeza a la Medusa, volviendo la suya al escudo que sostiene Athenea, situada a su derecha (Fig. 11) ${ }^{19}$. Una variante del mismo episodio se documenta en una lastra "campana", terracota pintada del 36-28 a.C., conservada en el Antiquarium del Palatino, procedente del templo de Apolo, en el que aparecen Athenea y Perseo flanqueando la enorme cabeza de la Gorgona que el héroe sotiene en su mano izquierda, después de ha-

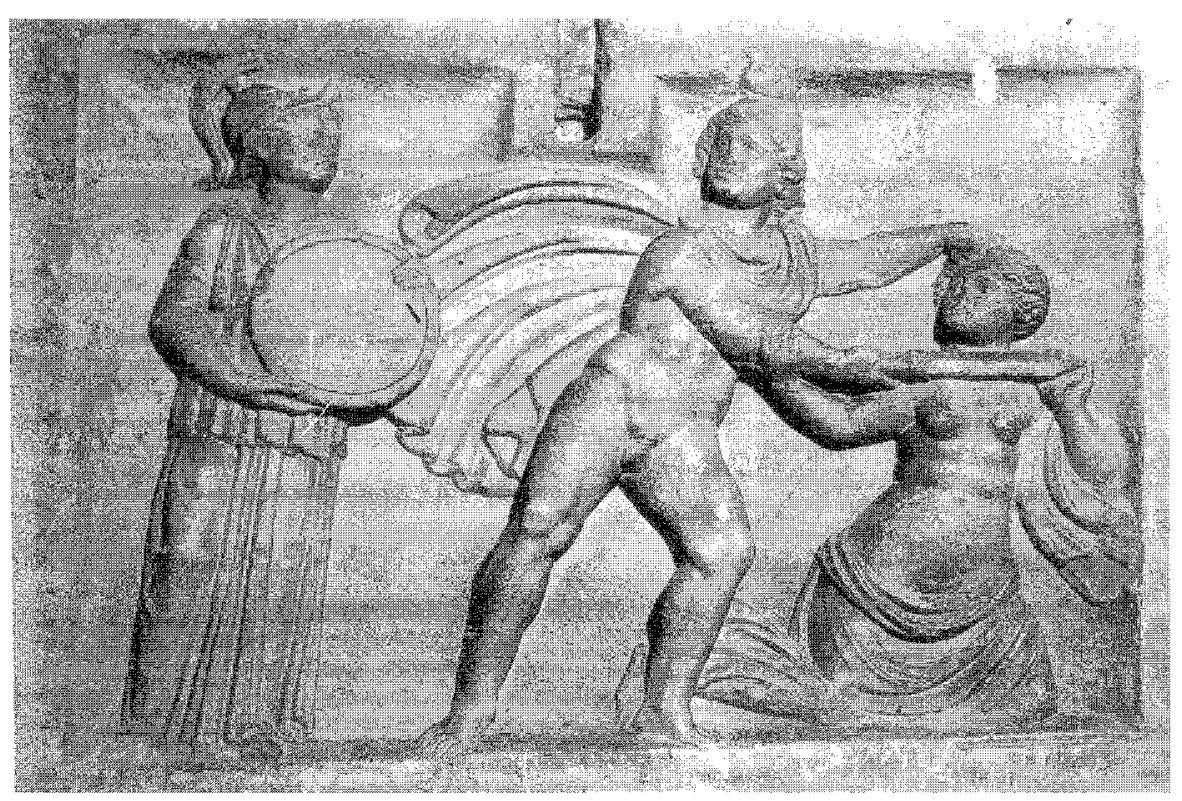

Figura 11. Decapitación de la Medusa. Relieve de Aquincum.

18 Los ejemplos de este episodio son poco frecuentes en comparación con el otro momento del mito, no recogido en las fuentes literarias y que parece ser una creación exclusivamente artística de comienzos del siglo $\mathrm{V}$ a.C., en el que Perseo contempla junto a Athenea la cabeza de la Medusa reflejada en el escudo o en el agua (vid. infra), cf. L. BALEnsiefen, Die Bedeutung des Spiegelgebildes als ikonographisches Motiv in der antiken Kunst, Tübingen 1990, págs. 113-130.

19 LIMC VII, «Perseus», núm. 132. 
berle dado muerte mirando de frente al escudo que le ofrece la diosa
(Fig. 12) ${ }^{20}$.

El reflejo de la cabeza de la Medusa en el escudo de Athenea tiene un gran contenido alegórico, ya que evidencia el juego sutil del lenguaje mítico en torno al tema del ojo y de la mirada, de la reciprocidad de ver y de ser visto, de la imagen y de su reflejo. E. Phinney considera que el escudo es, como el espejo, una metáfora del tiempo porque, al igual que el tiempo, el espejo permite mostrar indirectamente lo que la mirada no puede captar de forma directa ${ }^{21}$. Es decir, el espejo, por el que Eurípides expresa tanto interés en sus tragedias, le muestra a Perseo la importancia que la cabeza de la Medusa va a tener en posteriores hazañas, como es la muerte del kethos que guardaba a Andrómeda, o la petrificación de Atlante, de Phineus y sus cómplices y también de Polidektes, convirtiéndose de esta manera en una metáfora, en una alegoría del tiempo que está por venir. Así puede interpretarse un relieve del Palazzo Mattei en Roma, presidido por la imagen de Venus sentada en su concha sostenida

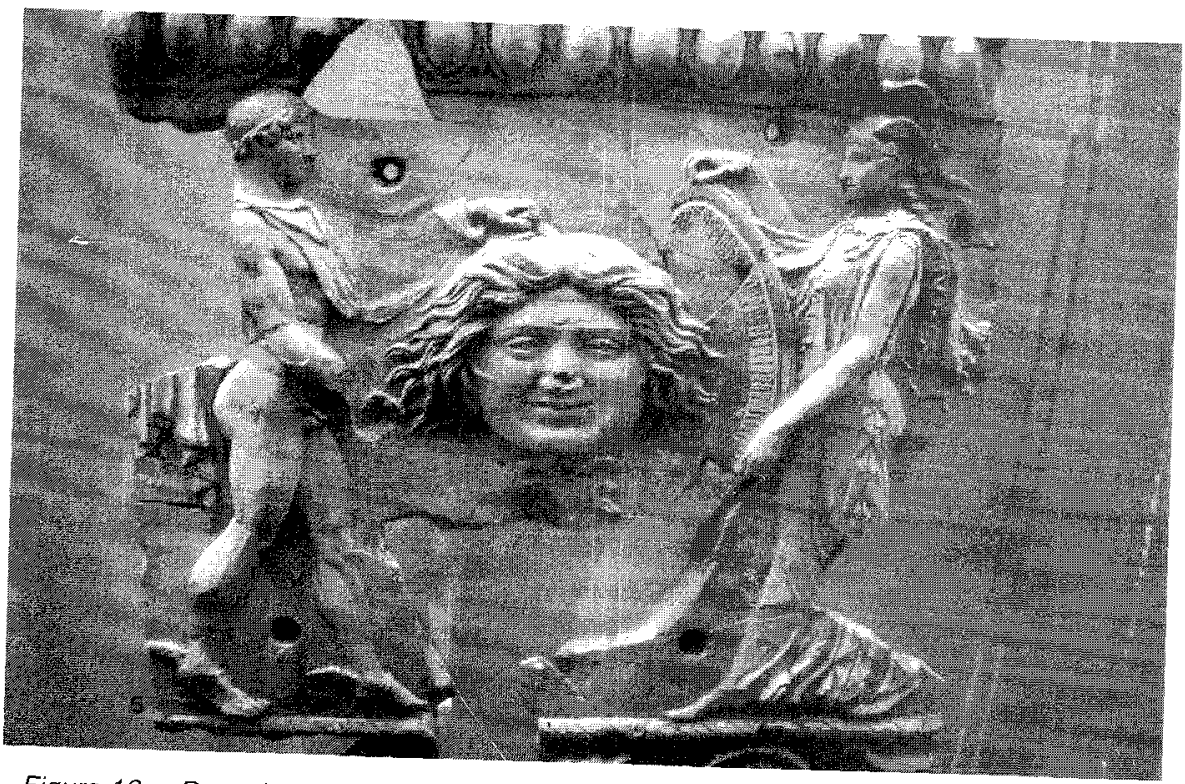

Figura 12. Decapifación de la Medusa. Lastra campana del Antiquarium Palatino, Roma. Foto G. López Monteagudo.

20 LIMC IV, “Gorgones Romanae», nüms. 190-192

21 E. Phinney, Perseus' Battle with the Gorgons, TAPA 102, 1971, pags. 445-463. 
por dos tritones, en el que se representan las dos hazañas que el héroe realiza sucesivamente en el extremo Occidente (Fig. 13) ${ }^{22}$. A la izquierda aparece Perseo que acaba de matar a la Gorgona, cuya cabeza sujeta en la mano izquierda, volviendo la suya hacia el escudo que le muestra Athenea; a la derecha se ha figurado a Perseo liberando a Andrómeda, con el gesto galante de ofrecerle su mano para ayudarla a descender de la roca, en cuya parte baja se encuentra el kethos ya muerto.

La musivaria romana ha proporcionado un solo ejemplo, en el pavimento de Conímbriga ( vid. infra), del momento inmediatamente posterior a la decapitación de la Medusa, cuando el héroe la sostiene ya en su mano. Esta imagen victoriosa de Perseo, sosteniendo en su mano la cabeza de la Medusa que acaba de cortar con la harpé, fué la que gozó de más favor en el arte antiguo, figurando en numerosas pinturas murales y de vasos, en espejos, esculturas, gemas y monedas, ofreciéndose algunas variantes en cuanto al tipo de arma utilizada. En el arte arcáico el héroe lleva espada y solo a partir del siglo $\vee$ a.C. aparece la harpé como atributo preferido, mientras que en vasos

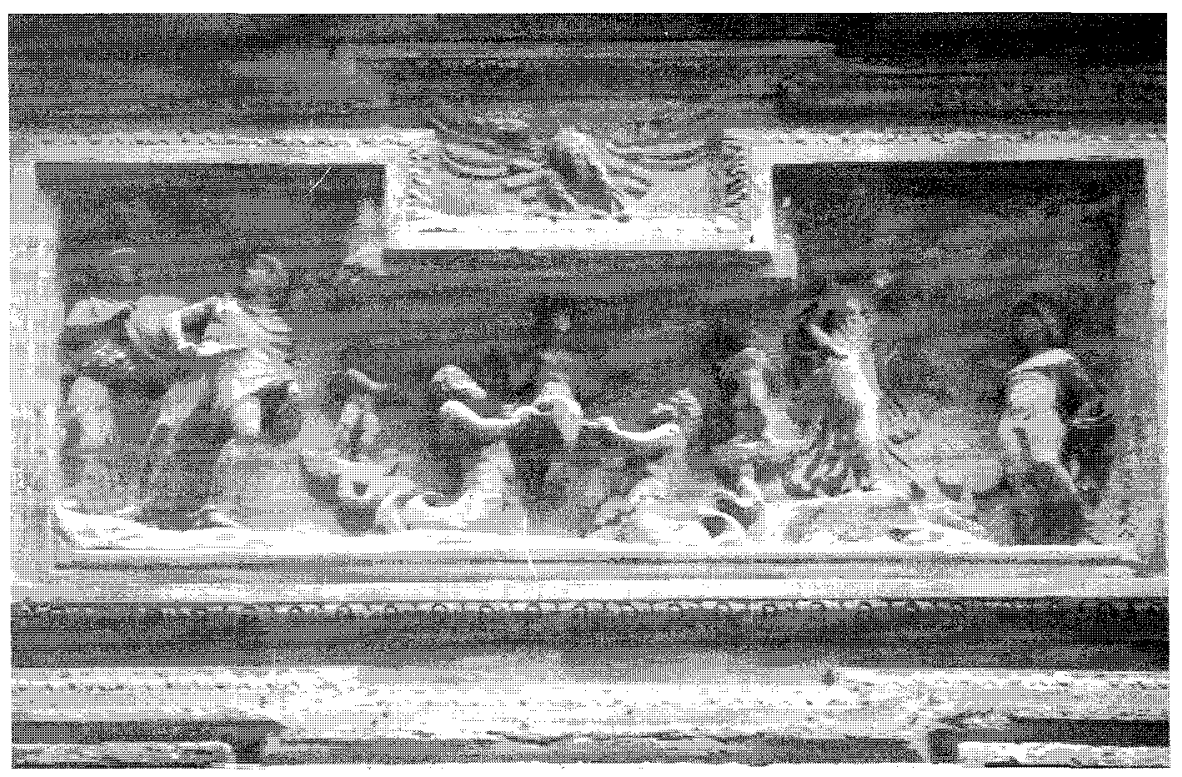

Figura 13. Decapitación de la Medusa y liberación de Andrómeda. Relieve del Palazzo Mattei, Roma. Foto G. López Monteagudo.

22 Cf. F. Matz-F von DuHn, Antike Bildwerke in Rom, I-III, Leipzig 1981-82, MD 2893; L. GueRRINI et alii, Sculture di Palazzo Mattei, Studi Micellanei 20, Roma 1971-72, pág. 10. 
de Italia meridional y en el arte romano se llega a un compromiso entre la espada y la harpé ${ }^{23}$. Por el contrario, en los mosaicos romanos Perseo lleva siempre la harpé, utilizándose el mismo tipo iconográfico para representar al héroe en el posterior espisodio de la liberación de Andrómeda.

El mosaico portugués de época severiana, procedente de la Casa de los Surtidores de Conímbriga, haciendo gala de la concisión que caracteriza a las imágenes representadas en todos sus pavimentos, ofrece una curiosa versión conjunta de ambas hazañas (Fig. 14). El héroe aparece de pie, en posición de tres cuartos en ligero movimiento hacia la izquierda, va desnudo con la clámide que, abrochada en el hombro derecho, cubre el izquierdo y cae a lo largo de la espalda, y lleva alas en la cabeza y no en los pies que aparecen desnudos; en la mano izquierda sostiene la harpé en posición vertical, mientras avanza la derecha con la cabeza de la Medusa para petrificar al kethos situado en la parte izquierda; en la zona superior del medalión se ha figurado un rython sujeto con cintas, instrumento dionisiaco que se repite, esta vez es una siringa, en el mosaico de Sileno sobre asno, procedente de la misma casa. La ausencia de Andrómeda en esta escena tal vez está

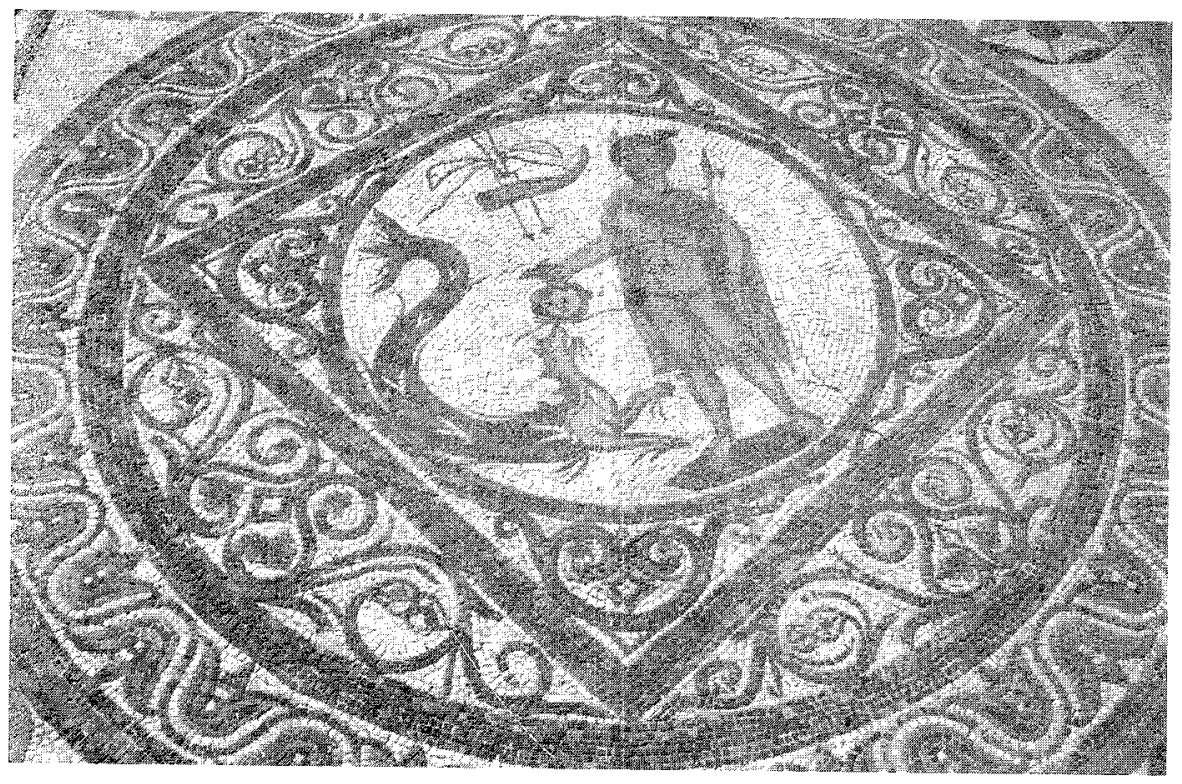

Figura 14. Perseo con el kethos y la medusa. Mosaico de Conimbriga. Foto G. López Monteagudo.

23 Cf. DMGR IV, «Perseus», págs. 398-406 
justificada por tratarse de una representación profiláctica, en la que prima la victoria del héroe contra las fuerzas del mal, encarnadas en el kethos y la medusa, sin olvidar un hecho notorio y es que en todo el programa iconográfico de esta casa faltan las representaciones femeninas, cuya presencia se limita a las figuras alegóricas situadas en las esquinas del mosaico del Auriga (horae y estaciones) ${ }^{24}$. Pero también podría interpretarse la escena portuguesa, precisamente por no haber ninguna alusión a la liberación de Andrómeda, como la victoria de Perseo sobre el terrible reptil, engendrado por Ketho y Forcis, cuya misión era custodiar las manzanas de oro del Jardín de las Hespérides (Hes. theog. 333-335), a donde, según algunos mitógrafos (Ov. met. IV 639 ss.; Lucan. phars. IX 654 ss.; Serv. ad Aen. IV 246), el héroe llegó después de cortar la cabeza de la Medusa y antes de acometer la siguiente hazaña, que fué liberar a Andrómeda. El jardín de las Hespérides se localiza en el Norte de Africa, allí donde, según Plinio (NHV 3-4,21), los meandros del rio Loukkos dibujaban la forma del monstruo que guardaba las manzanas de oro y donde algunas fuentes sitúan el episodio

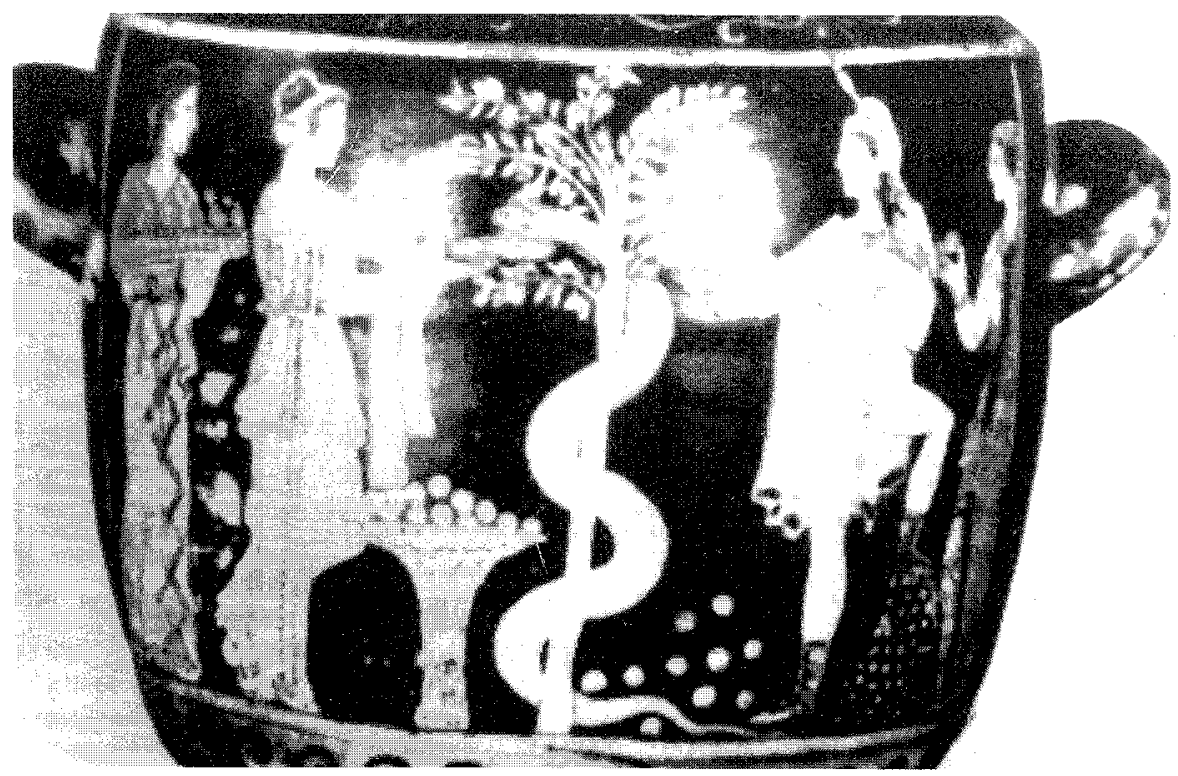

Figura 15. Perseo en el Jardín de las Hespérides. Hidria de la Col. Palmella (Lisboa).

24 J.M. Bairrao Oleiro, Conimbriga. Casa dos Repuxos, Conimbriga 1992, págs. 32-36, Est. 3; G. López Monteagudo, El programa iconográfico de la Casa de los Surtidores de Conimbriga, Espacio, Tiempo y Forma II/3, 1990, págs. 199-232. 
de Atlas ${ }^{25}$. Al parecer este acontecimiento solo se halla documentado iconográficamente en una hidria de Paestum de la colección Palmella de Lisboa, datada en 340-330 a.C., en la que se ha figurado al héroe con chlamis, gorro frigio y lanza a la izquierda, en compañia de las tres hespérides, junto al árbol custodiado por la serpiente y cuyos frutos caen al suelo o son recogidos en cestos y bandejas por las jóvenes (Fig. 15) ${ }^{26}$. Los documentos iconográficos que hacen referencia a esta secuencia del mito muestran una contaminación con la estancia de Hércules también en el jardín de las Hespérides, al igual que la liberación de Andrómeda por Perseo y de Hesión por Hércules, por lo que a veces y ante la ausencia de algún elemento claramente identificador, por ejemplo la maza, es díficil distinguir de qué héroe se trata, como ocurre en el citado mosaico de Thina (vid. infra).

Los paralelos más próximos a la escena de Conímbriga se encuentran en monedas de Mitrídates VI Eupator (121-63 a.C.) (Fig. 16) y en pinturas

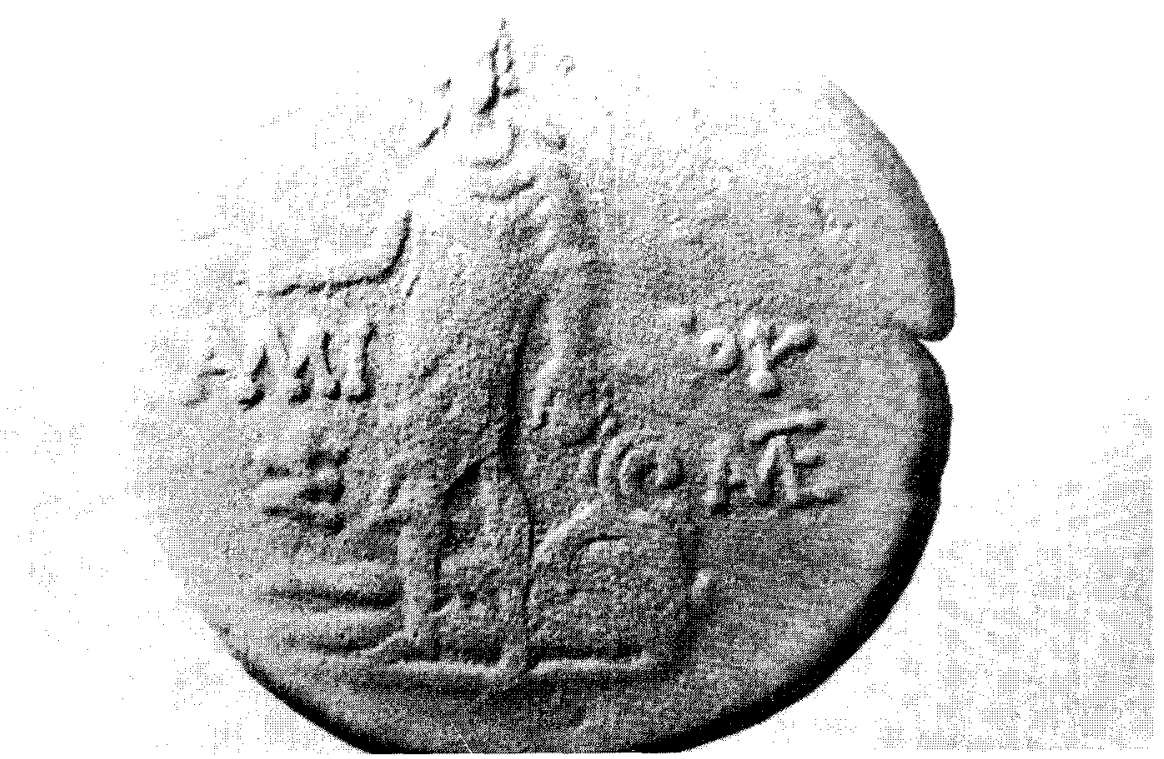

Figura 16. Perseo con el kethos y la medusa. Moneda de Mitridates VI Eupator.

25 Un estudio reciente sobre el jardín de las Hespérides en F. DíEZ DE VELASCO. Mitos, símbolos e imágenes de la Grecia Antigua, Madrid 1998, págs. 75-129.

26 K. Schauenburg, Perseus und der Kunst des Altertums, Bonn 1960, págs. 88-89, Taf. 35.2; M.H. Rocha Pereira, Greek Vases in Portugal, Coimbra 1962, págs. 103-115, n.. 43, pl. LIV-LVIII. 


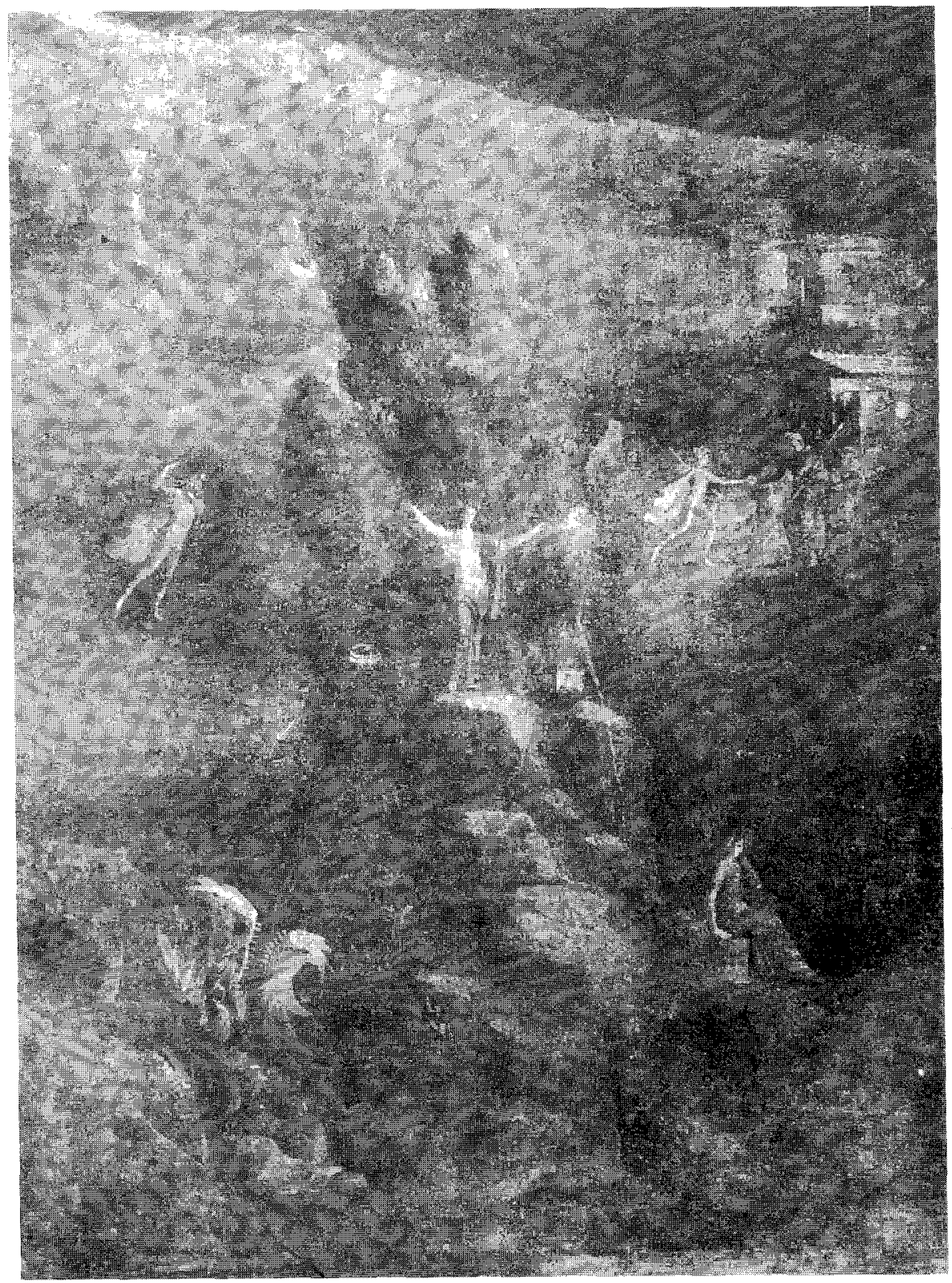

Figura 17. Perseo volando hacia la roca donde se halla encadenada Andrómeda. Pintura de Pompeya. 
pompeyanas, en las que Perseo aparece volando sobre el mar, con la cabeza de Medusa en su mano izquierda y la harpé en la derecha, dirigiéndose al kethos que se halla dentro del agua junto a la roca a la que está encadenada Andrómeda (Fig. 17) ${ }^{27}$. Seguramente a este tipo iconográfico hay que adscribir el fragmento musivo de Trier (Fig. 18), datado en el tercer cuarto del siglo $\|$ d.C., en el que se ha representado una figura masculina con manto flotante sobre la espalda, espada a la cintura, escudo oval en la mano izquierda y lanza en la derecha, por la presencia a su izquierda de un monstruo marino, solo conservado en parte, y por su semejanza iconográfica con un relieve del Landesmuseum de Graz (Fig. 19) ${ }^{28}$.

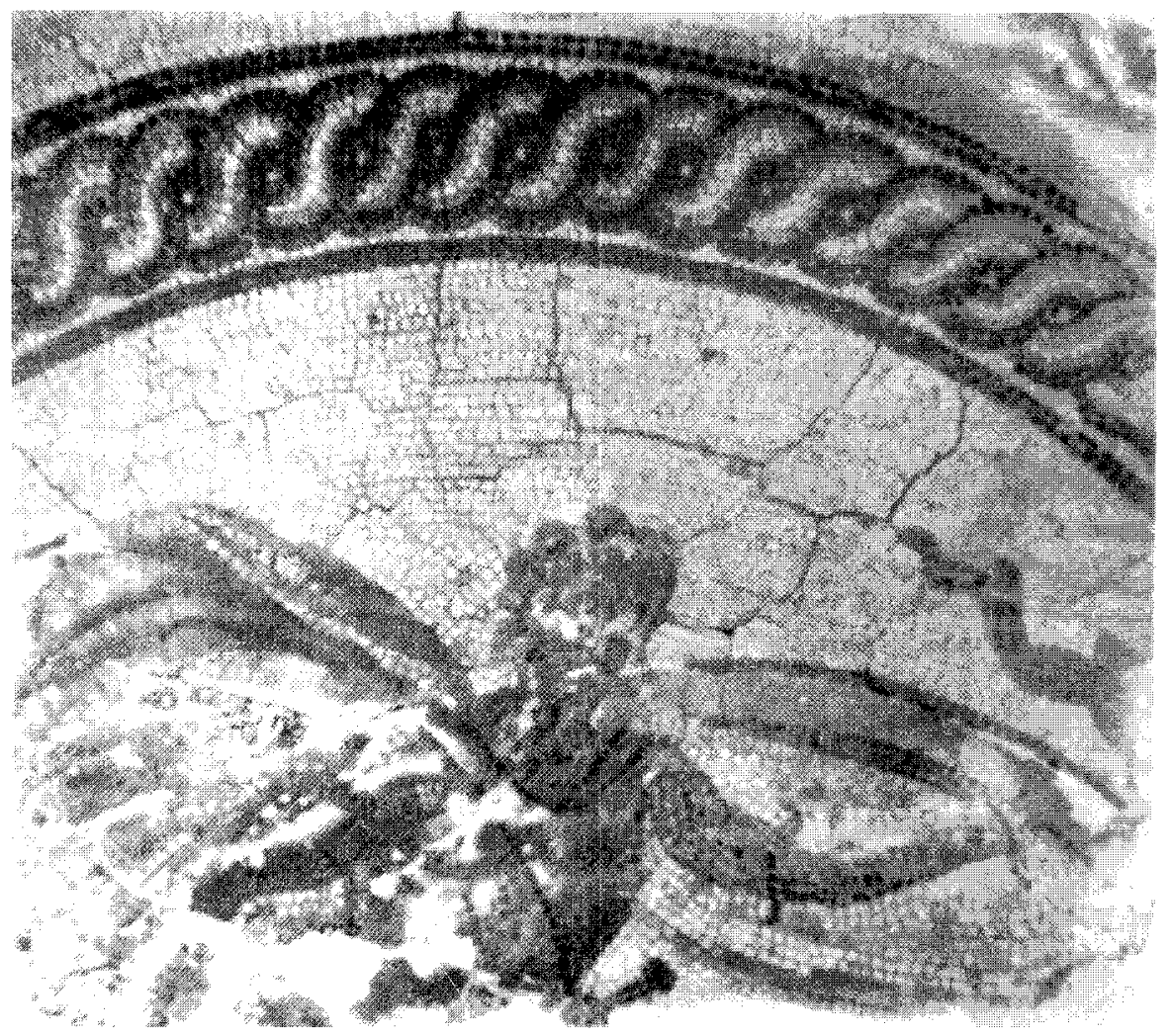

Figura 18. Perseo volarido hacia el kethos. Mosaico de Trier.

27 LIMC VII, «Perseus», núms. 123 y 178; LIMC I, “Andromeda 1", núms. 37-40.

28 K. Parlasca, Die römischen Mosaiken in Deutschland, Berlín 1959, pág. 23, Taf. 29.1; K. Schauenburg, Perseus und der Kunst des Altertums, Bonn 1960, págs. 69-70, nota 450, Taf. 29.2. 


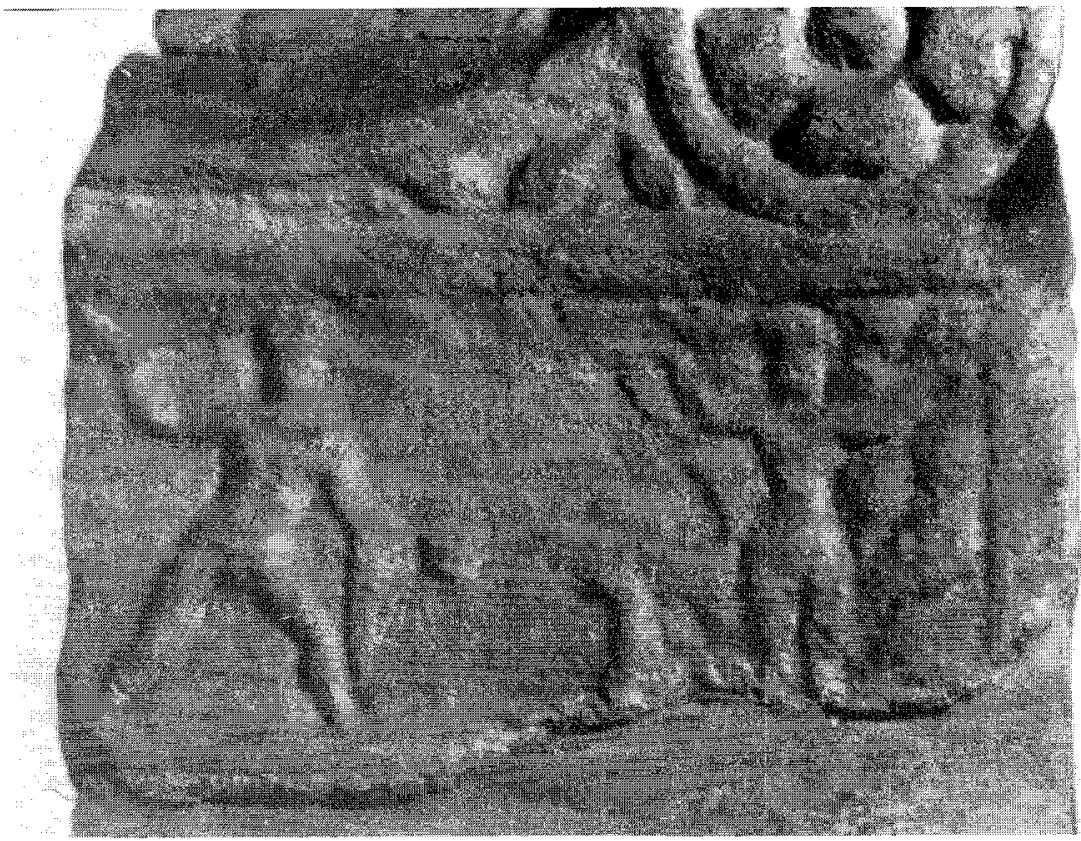

Figura 19. Perseo Lichando contra el kethos. Relieve del Landesmuseum de Graz.

El encuentro de Perseo y Andrómeda inmediatamente antes de suliberación se representó en el mosaico de Cassiopea en Palmyra, de época bajo-imperial, que muestra a Andrómeda sentada y encadenada a la roca (Fig. 20) ${ }^{29}$. Según H. Stern, es lamentable que falte la parte derecha de este cuadro, en el que seguramente figuraba Perseo, porque constituye un conjunto de un intenso dramatismo, subordinado a la escena principal de Poseidón y Cassiopea. Los paralelos más próximos para el tipo iconográfico de Andrómeda sentada y encadenada se encuentran en un oinochoe apulio del Museo de Bari, procedente de Canossa (Fig. 21), del último cuarto del siglo iv a.C., y en varias urnas de Volterra de fines del siglo 111 o comienzos del $1{ }^{30}$. Al parecer, las primeras referencias directas a Andrómeda encadenada a la roca, espiando las palabras proferidas por su madre Cassiopea de ser la más bella de las nereidas, remontan al siglo । a.C. (Prop. 3. 22,29; Ov. met. IV 663 ss.), aunque seguramente la tradición viene de comienzos del siglo II! a.C.

29 H. Stern, Les mosaïques des maisons d'Achille et de Cassiopée à Palmyre, París 1977, págs. 26-42, fig. 44

30 K.M. PHiLLIPS, Perseus and Andromeda, AJA 72, 1968, págs. 1-23, figs. 38-40, 43 y 44. 
(Tzetz. Lycophr. 836-839) e incluso de finales del v, encontrándose más tarde en Apollodoro (bib/. II, 4,3) ${ }^{31}$.

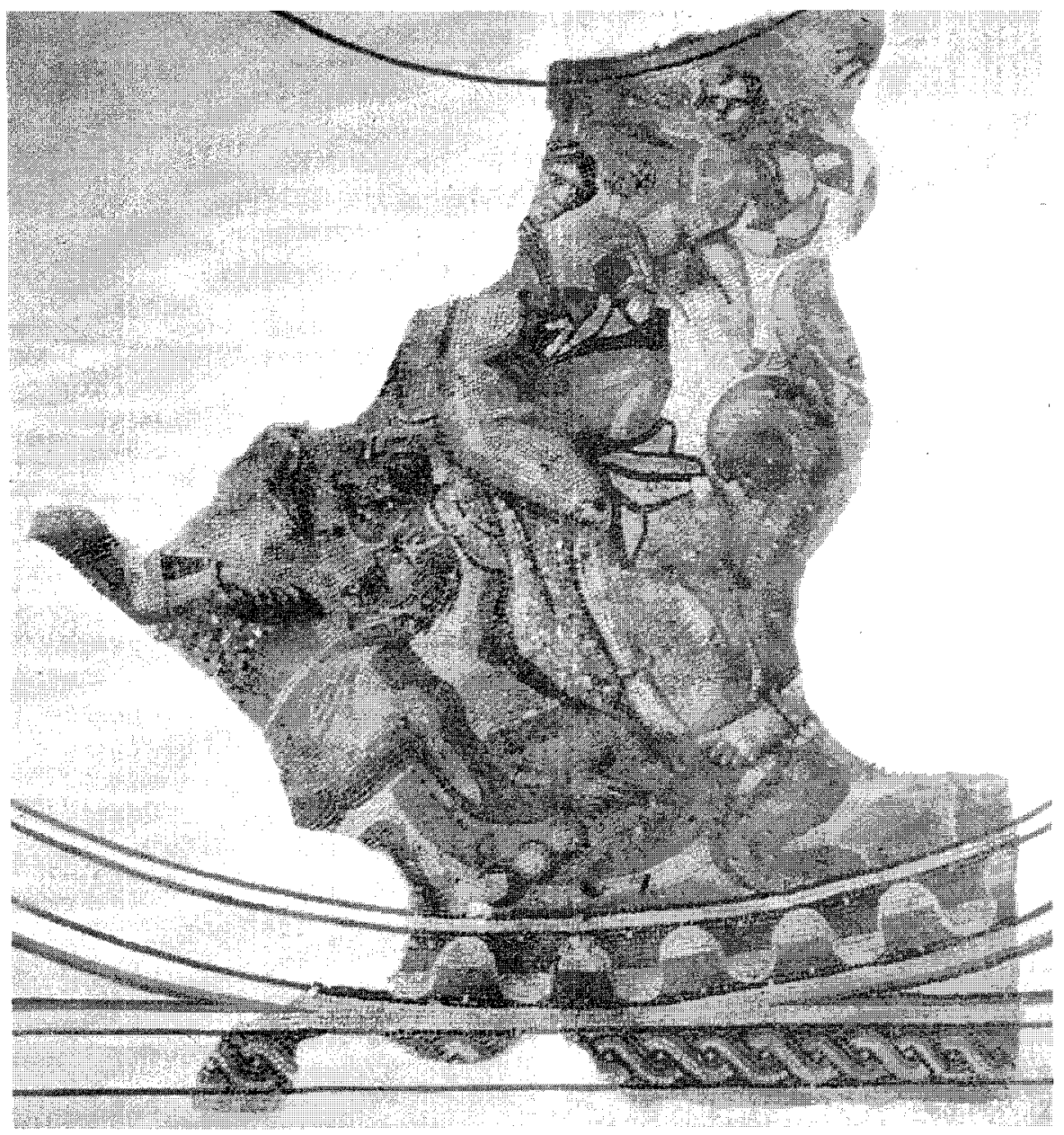

Figura 20. Andrómeda sentada encadenada a la roca. Mosaico de Cassiopea, en Palmyra. Foto G. López Monteagudo.

31 El mito de Cassiopea se ha figurado, además de en el mosaico de Palmyra, en dos pavimentos bajo-imperiales procedentes del Oriente, Nea Paphos (cf. W.A. DAszeWSkI, Dionisos der Erlöser, Mainz 1985, págs. 29-33, Taf. 7-8; W.A. Daszewski, M. Michaelides, Guide des mosaïques de Paphos, Nicosia 1989, págs. 63-71, Figs. 48-49) y Apamea (cf. J. BALTY, Iconographie et réaction païenne, Mélanges P. Levêque, 1, París 1988, págs. 17-32). 


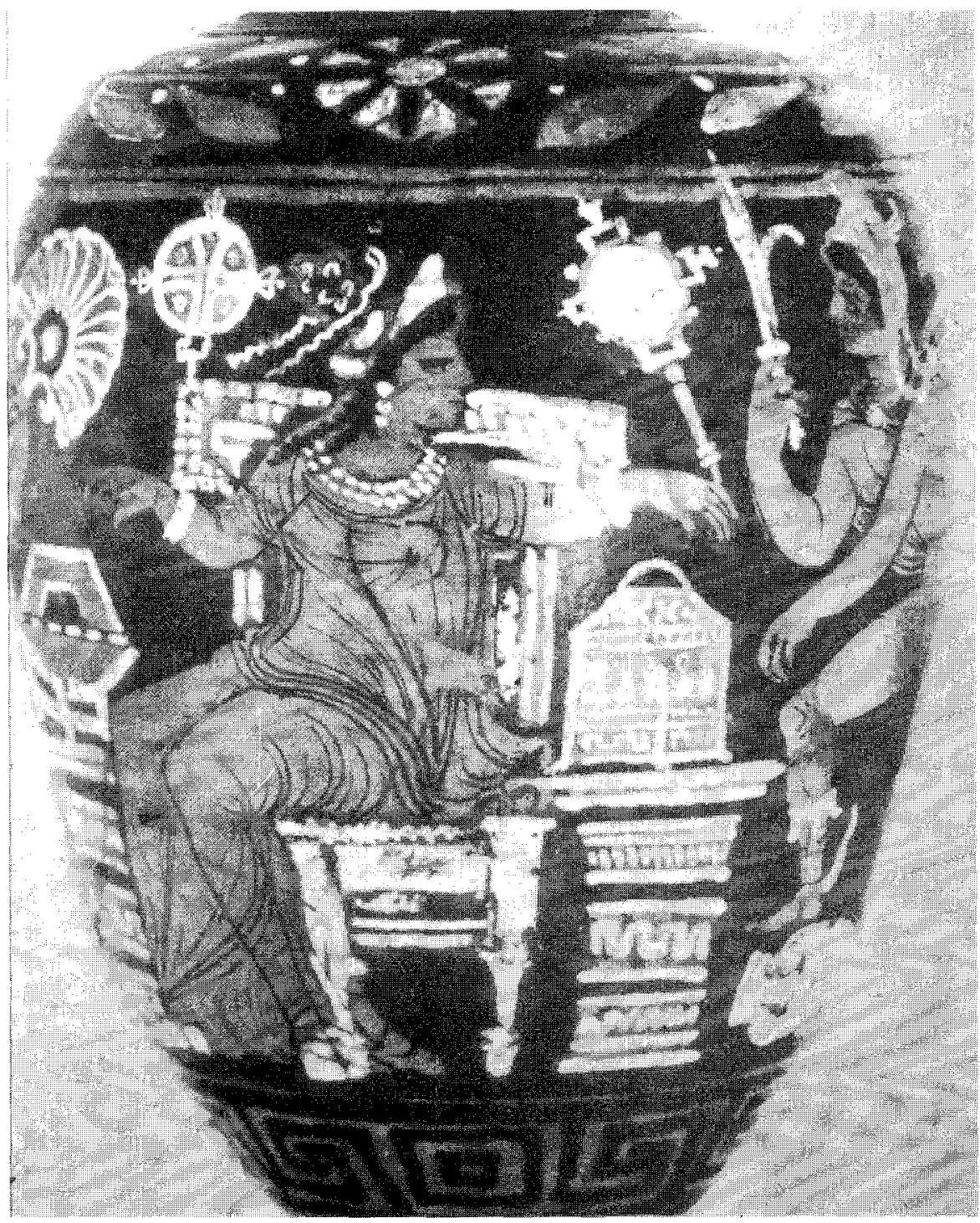

Figura 21. Andrómeda sentada encadenada. Oinochoe apulio de Canossa, Museo de Bari. 
La composición básica de Andrómeda encadenada a la roca se documenta en el área de Tarento durante el siglo Iv a.C., de donde pasa, tras su desarrollo en el III y II a.C., a la pintura pompeyana, en la que K.M. Phillips distingue cinco tipos básicos en la iconografía de Andrómeda encadenada a la roca, que responden a distintos momentos del mito; en todos la heroína se halla en pie de frente, mientras que Perseo vuela hacia su rescate, lucha con el monstruo marino, está en pie a su lado o la ayuda a descender de la roca 32.

Uno de estos episodios se representó en el mosaico hispano de Tarragona, datado en época severiana, en el que se ofrece una interesante variante iconográfica de la liberación de Andrómeda (Fig. 22) ${ }^{33}$. La escena del único de los cuatro cuadros conservados, que rodeaban el emblema. con la cabeza de la Medusa (vid. infra), sigue fielmente el relato de Lycophron (Tzetz. Lykophr. 836-839), que sitúa este episodio entre dos rocas, localizadas por Estrabón (XVI 2,28), seguido por Plinio (NHV 69) y

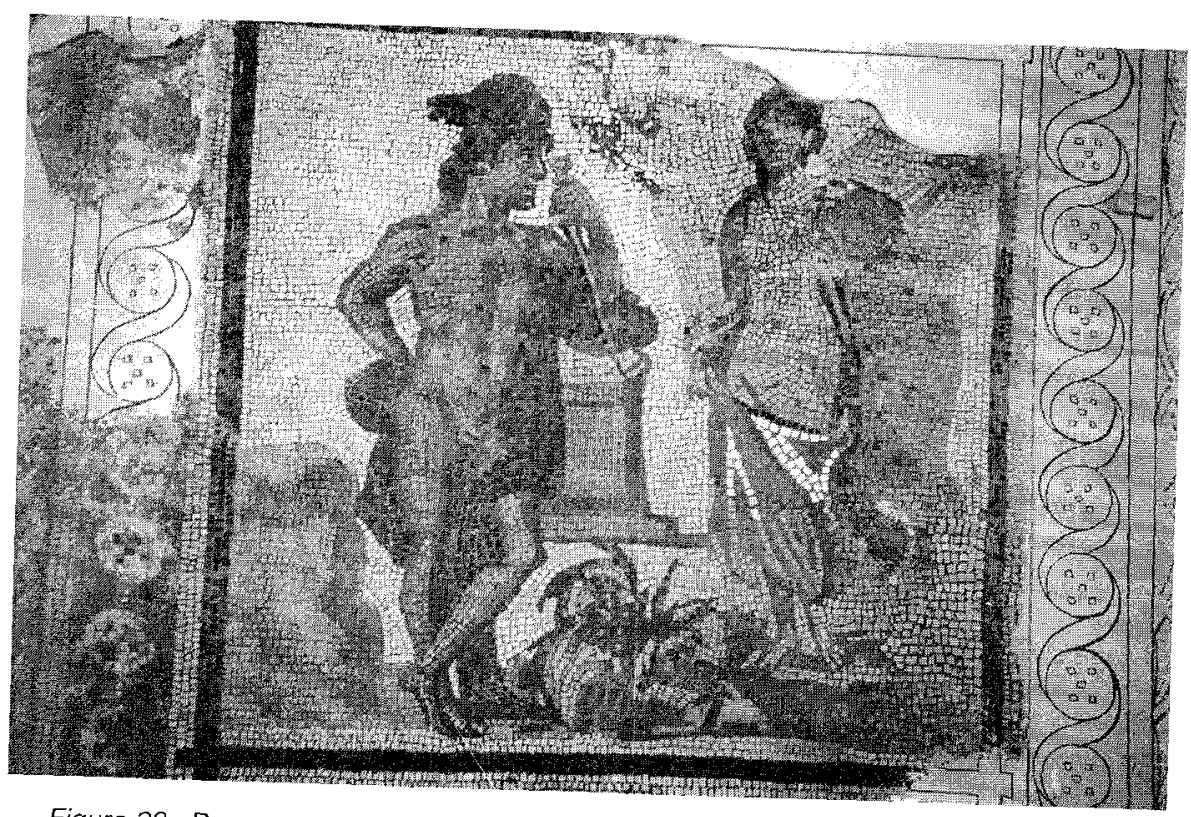

Figura 22. Perseo contemplando a Andrómeda. Mosaico de Tarragona. Foto G. López Moriteagudo.

3. K.M. Phillips, Perseus and Andromeda, AJA 72, 1968, págs. 1-23.

A. BaLIL, II mosaico "della Medusa" di Tarragona, Hommages à $M$. Renard III (=col. Lato-
mus n. 103), Bruxelles 1969, págs. $3-12$ Tavv I-lli 
Josephus (bell. iud. III 9,3;419, 421), en la ciudad fenicia de Joppa en donde, según este último, aún en su tiempo se distinguían sobre el acantilado las huellas de las cadenas. El héroe se encuentra de pie delante de una roca, en actitud de reposo, como indica la posición flexionada de su pierna izquierda y el brazo del mismo lado apoyado en un ara, que también aparece en el mosaico de Bulla Regia (vid. infra); va desnudo, con la chlamis colgada del hombro izquierdo y sostenida con la mano derecha por detrás de la cintura. Cubre la cabeza con yelmo alado y sostiene en la mano izquierda la harpé; a sus pies yace el kethos ya muerto. En la parte de la derecha aparece Andrómeda vista de frente, con la mano izquierda encadenada aún a la roca, en donde cuelga la cadena y la argolla del brazo derecho ya libre, detalle que se repite en el pavimento de Antioquía (vid. infra); lleva manto sobre la espalda que recoge con la mano derecha en la parte delantera, intentando cubrir su cuerpo desnudo con gesto pudoroso, como en los mosaicos de Bulla Regia y Antioquía (vid. infra). Pero a diferencia de estos y de las pinturas pompeyanas, o de los relieves y otros soportes, en el mosaico hispano Perseo no lleva la cabeza de Medusa ni ofrece su mano a Andrómeda, simplemente descansa después de haber dado muerte al monstruo contemplando a la joven, iconografía que puede compararse con la de una pintura de pequeño tamaño descubierta en la pared posterior del oecus núm. 16 de la Casa de Menandro en Pompeya (Fig. 23), o con las composiciones figuradas en algunos relieves de época helenística y romana, como un relieve estucado de Pozzuoli (Fig. 24), documentos en los que Andrómeda aún aparece encadenada con ambas manos a la roca, y sobre todo con una cerámica tunecina de comienzos del siglo IV en la que se ve a Andrómeda encadenada entre dos rocas, con la mano derecha ya suelta como en Tarragona, Perseo a su derecha y en la parte inferior el kethos y el cofre haciendo alusión al episodio de Dánae y Perseo (Fig. 25) ${ }^{34}$. Esta iconografía tan poco habitual, en la que el héroe, con o sin la cabeza de Medusa, contempla la belleza de la joven aún encadenada y la posterior conversación antes o después de haber matado al monstruo, parece inspirarse en poetas tempranos como Eurípides (TGF frg. 145). El mosaico de Tarragona constituye, pues, por las particularidades iconográficas apuntadas, un interesante ejemplo de la conjunción de influencias griega y romana en una misma escena. La simple conversación entre los protagonistas es el tema favorito de las gemas que, por su espacio limitado, no permite muchos detalles.

34 A. Maluri, La Casa del Menandro e il suo tesoro di argenteria, Roma 1932, pág. 163, fig. 77; LIMC I, «Aridromeda I», núms. 5-63. 
El episodio de Perseo liberando a Andrómeda del monstruo que la guardaba, tan popular en la iconografía clásica - se encuentra en pintura mural, gemas, monedas y lucernas del siglo I d.C., siguiendo un modelo clásico - adquiere en el arte romano un rasgo de galantería al presentar al héroe dando la mano a la joven para ayudarla a bajar de la roca. Este

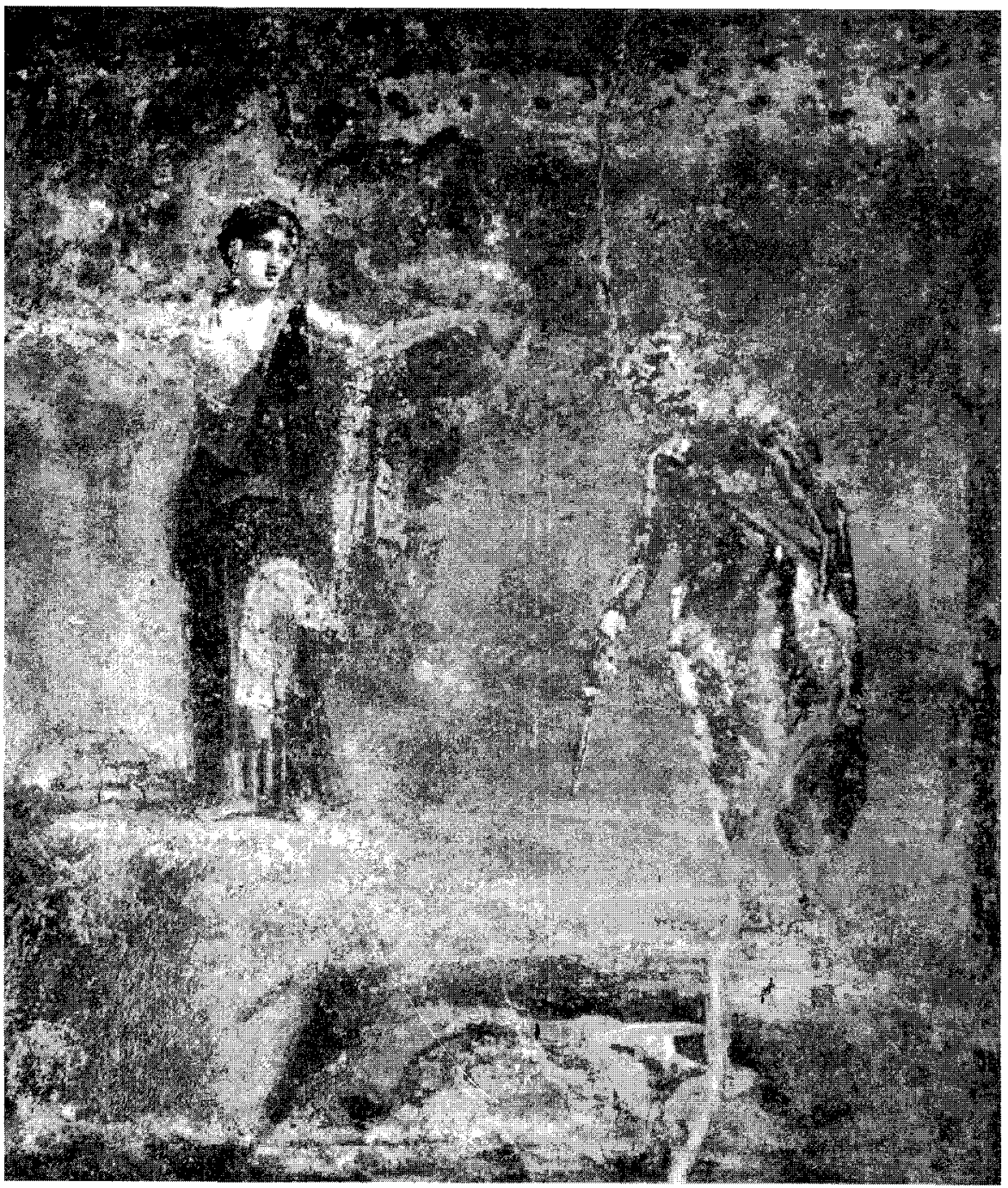

Figura 23. Perseo contemplando a Andrómeda. Pintura de la Casa de Menandro en Pompeya. 


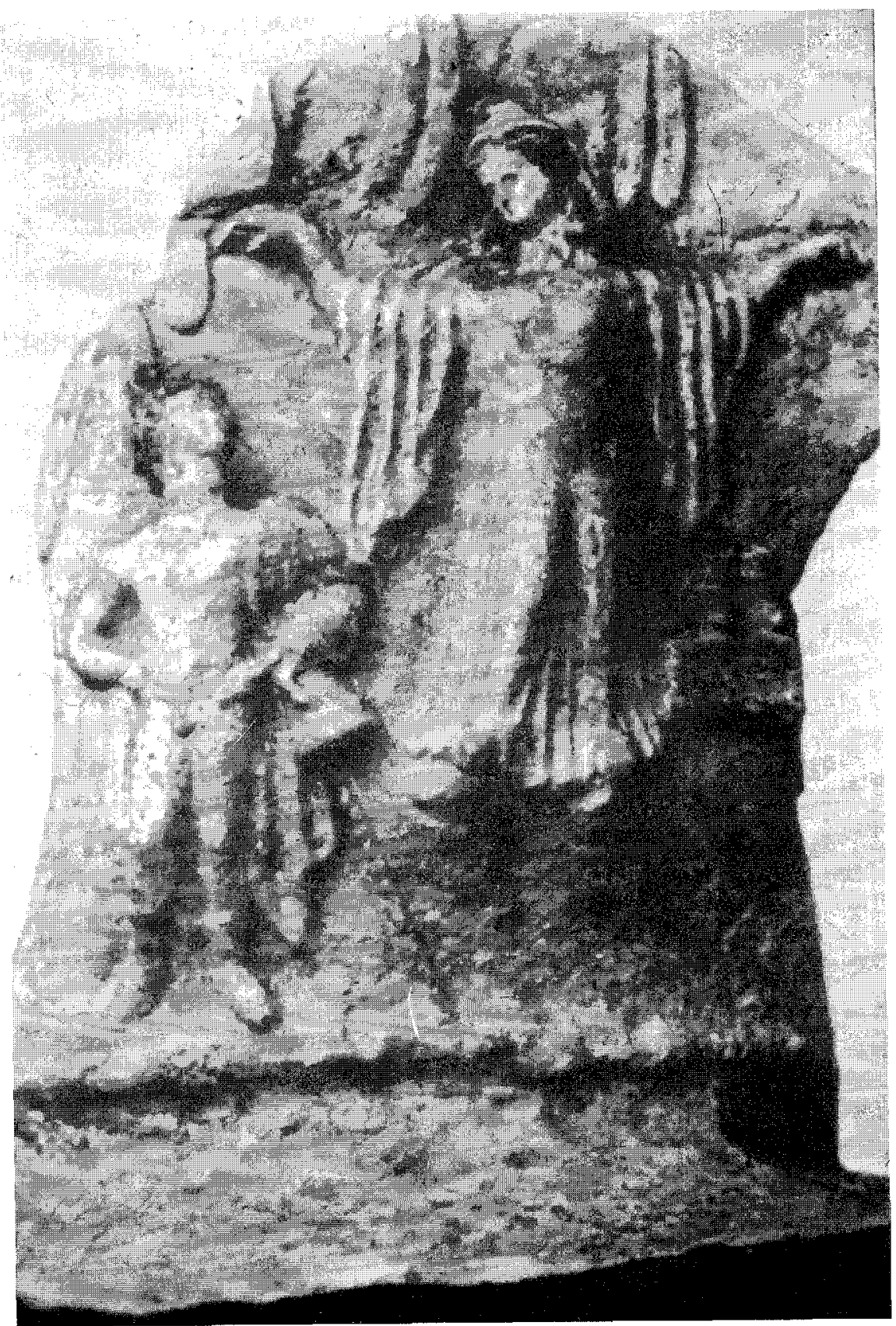

Figura 24. Perseo contemplando a Andrómeda. Relieve estucado de Pozzuoli. 


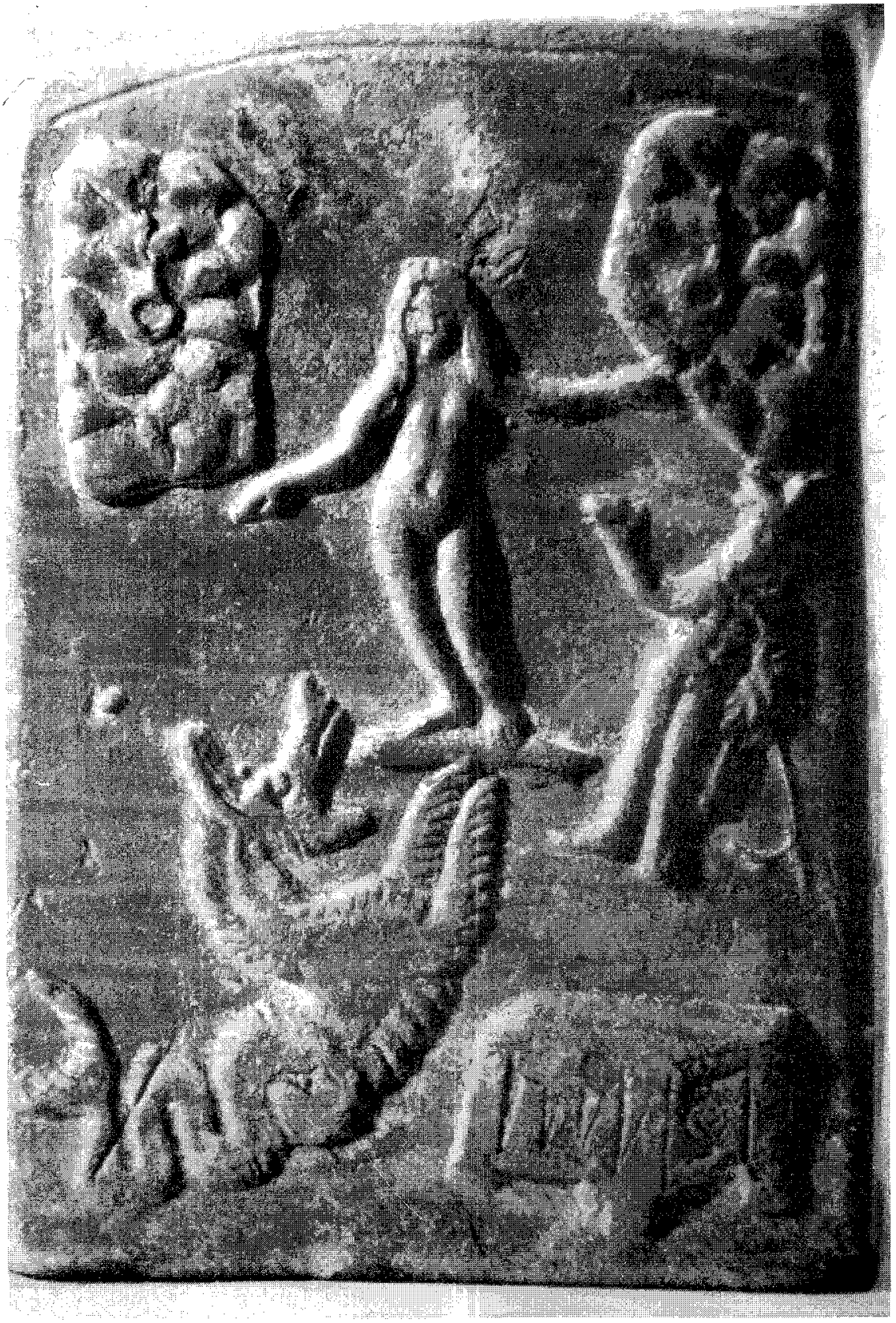

Figura 25. Perseo contemplando a Andrómeda. Cerámica de Túnez. 
tipo iconográfico fué el más utilizado en la musivaria de época romana, con documentos fechados en los siglos $\| \mathrm{y} \mathrm{IV}$, que junto a la pintura del Antiquarium Comunale de Roma, constituyen los ejemplos más tardíos.

En el mosaico procedente del oecus de la Casa de Anfitrite en Bulla Regia, fechado a mediados del siglo III, que se conserva en el Museo de El Bardo, la escena se desarrolla en un litoral rocoso donde el héroe, situado a la derecha delante de un ara, como en el mosaico de Tarragona, ayuda galantemente a la joven a bajar de la roca, a la que se hallaba encadenada, cogiéndola de la mano (Fig. 26). Ambos aparecen desnudos, con manto sobre sus espaldas y recogido en las piernas con gesto pudoroso el de Andrómeda. Perseo lleva en la mano izquierda la cabeza de Medusa y la harpé. En la parte baja aparece, entre los dos protagonistas la personificación de una divinidad del mar, quizás el mismo Neptuno en recuerdo del castigo impuesto a Andrómeda por el padre de las nereidas, quedando el kethos desplazado dentro del agua en el ángulo inferior derecho ${ }^{35}$.

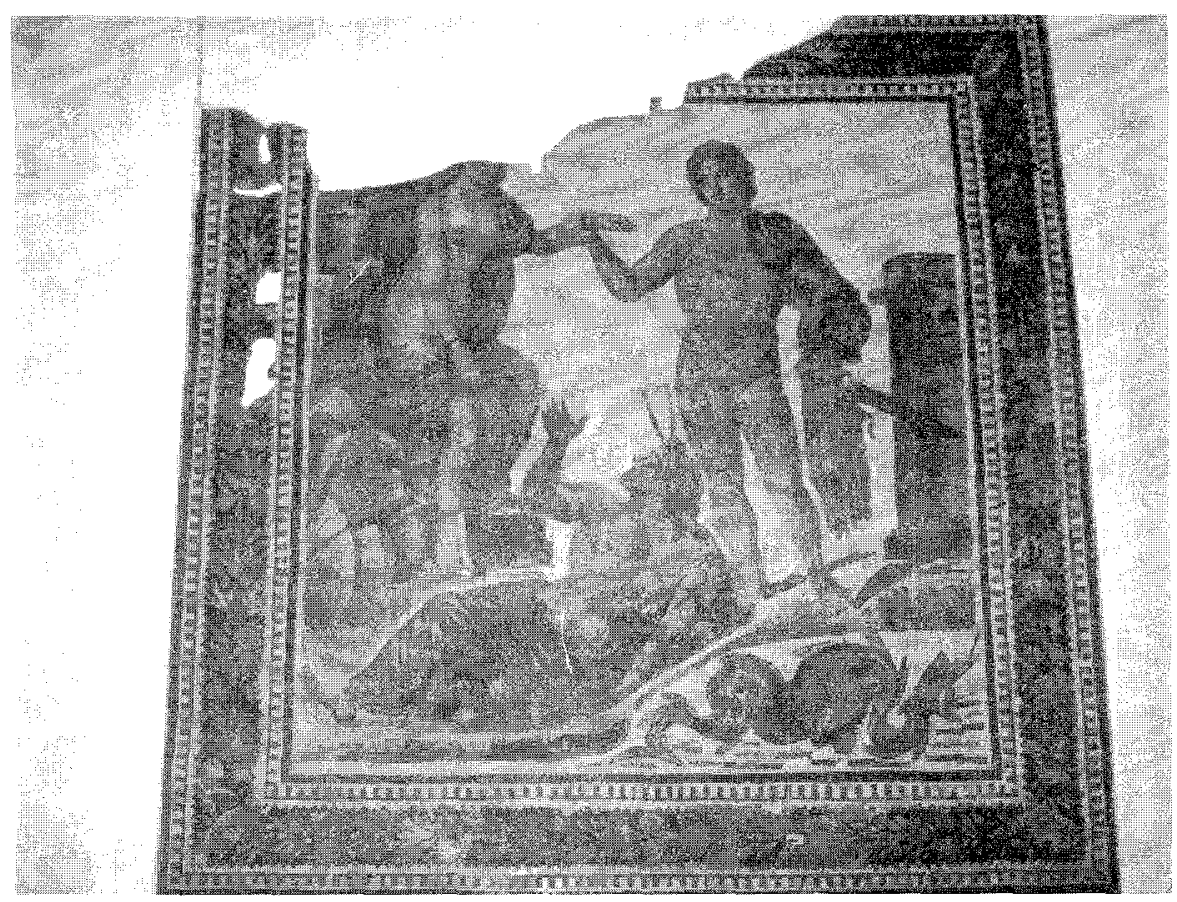

Figura 26. Perseo liberando a Andrómeda. Mosaico de Bulla Regia. Foto G. López Monteagudo.

35 K.M.D. Dunbabin. The Mosaics of Roman North Africa, Oxford 1978, pág. 250, pl. 9. 
Un paralelo muy próximo, aunque de peor calidad, lo constituye el mosaico del corredor de la Casa de Dionisos y Ariadna en Antioquía, que M. Donderer fecha a comienzos del siglo III (Fig. 27) ${ }^{36}$. Andrómeda aparece vestida, como es normal en la iconografía del Oriente ${ }^{37}-$ baste recordar las representaciones del Rapto de Europa en los mosaicos de Byblos, Daphne y Sarrîn - y a pesar de ello, se la ha representado con el típico gesto pudoroso de cubrirse con el manto, al igual que en Tarragona y Bulla Regia, mientras que Perseo le ayuda a bajar de la roca a la que se hallaba encadenada, en la que cuelga la cadena ya suelta, como en el mosaico de Tarragona. El héroe va completamente desnudo, con manto sobre la espalda y alas en los pies; en la mano izquierda flexionada, tal vez sobre un ara como en los pavimentos de Tarragona y Bulla Regia, sostiene la harpé y la cabeza de la Medusa. El cuadro forma parte de una serie de paneles decorados con temas dionisiacos, evidenciando la conexión del mito de Perseo con el thiasos

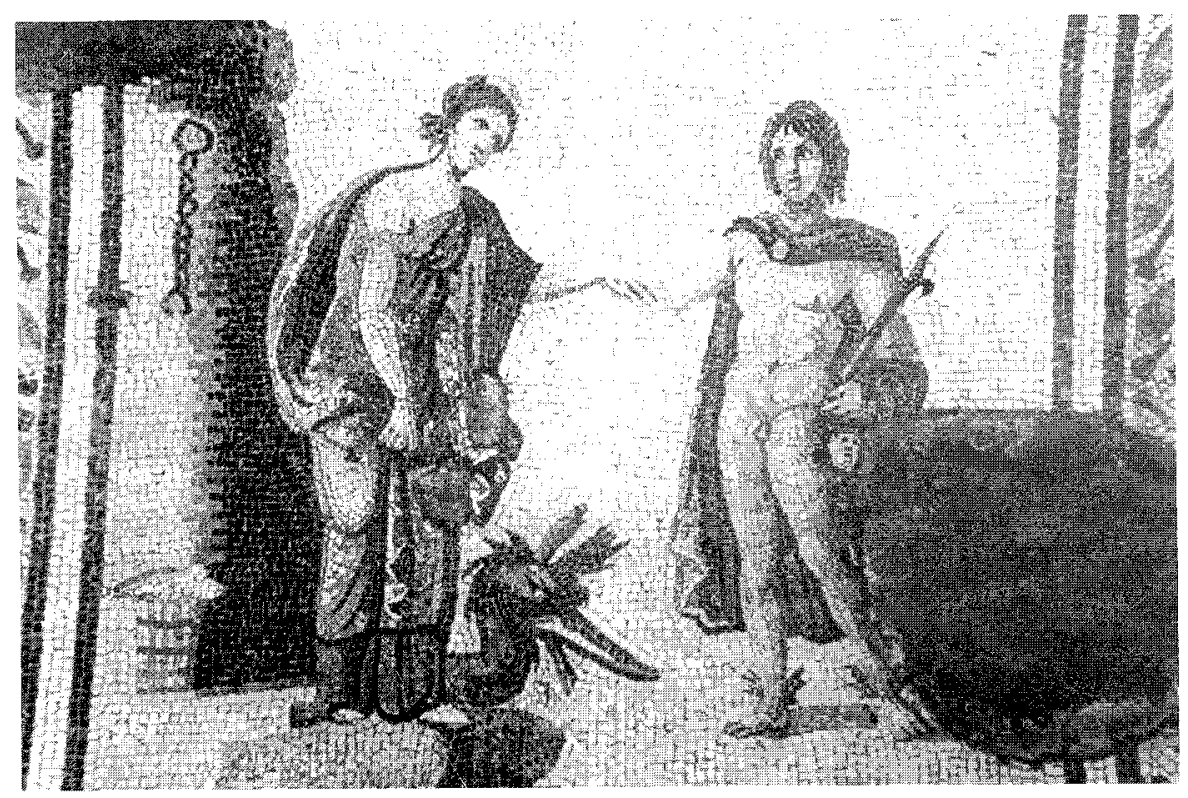

Figura 27. Perseo liberando a Andrómeda. Mosaico de Antioquía.

3o D. Levi, Antioch Mosaic Pavements, Princeton 1947, págs. 150-156, Fig. 58, PI. XXIX b-c.

37 G. López Monteagudo, M.P. San Nicolás Pedraz, El mito de Europa en los mosaicos hispano-romanos. Análisis iconográfico e interpretativo, Espacio, Tiempo y Forma Il/8, 1995, págs. $430-431$. 
báquico (Paus. II 20,4; 22,1; 23,7; Euphorion, frg. 18; Nonn. dion. 47, 498-741), relación que se manifiesta también en otros pavimentos, como en el de la villa de Brading (vid. infra), con la inclusión de sátiros y bacantes, o con instrumentos báquicos como en Conímbriga (vid. supra).

La escena se repite en uno de los ángulos de la orla del mosaico de la Toilette de Venus, procedente de la Casa del Asno en Djemila, con la particularidad de que el fondo marino se impone en toda la escena, de forma que Perseo, completamente desnudo y estante sobre el agua negra, donde agoniza entre ambos personajes el kethos herido de muerte, invita a Andrómeda, que también aparece desnuda y con el manto sobre las piernas cubriendo púdicamente el sexo, a descender de la roca dentro del mar, tomándola en esta ocasión de la mano derecha (Fig. 28). Sin embargo, ni el estilo ni la técnica del pavimento argelino pueden compararse con los ejemplares anteriores, sobre todo en la desproporción de las figuras que indican ya una fecha tardía, fines el siglo IV o comienzos de $V$. Según M. Blanchard-Lemée, las escenas mitológicas que ocupan los ángulos: Perseo y Andrómeda, los viajes de Ulises, Hero y Leandro y tal vez Arion, no tienen, igual que ocurre en Thina ( $v i d$. infra), más conexión entre sí y con el resto de los temas de la orla, que ser episodios marinos apropiados para la decoración de una diaeta de verano ${ }^{38}$

Perseo liberando a Andrómeda es, según K.M.D. Dunbabin, uno de los temas mitológicos incluidos, junto a Dánae y Perseo arribando a Seriphos, Dédalo, Venus en la concha, Scylla, Ulises y las Sirenas, Selene y Endimión, Leandro y Hero, erotes, nereidas y tritones, en el gran pavimento hexagonal de escenas marinas, presididas por Arion cabalgando sobre el delfín, del frigidarium de las Grandes Termas de Thina, que se data a fines del siglo III (vid. supra) ${ }^{39}$. La identificación de Perseo liberando a Andrómeda, propuesta por K.M.D. Dunbabin, se basa seguramente en la proximidad de este grupo al de Dánae arribando a la isla de Seriphos, aunque R. Massigli se inclina por Hércules y Hesión, interpretación que es más plausible a juzgar por lo que parece ser la leonté asomando por detrás del héroe (Fig. 7) ${ }^{40}$.

38 M. Blanchard-Lemee, Maisons à mosaíques du Quartier central de Djemila (Cuicul), Aix-enProvence 1975, págs. 65-84, pl. XIII-a.

39 K.M.D. Dunbabin, The Mosaics of Roman North Africa, Oxford 1978, pág. 273

40 R. Massigli, Musée de Sfax, Paris 1912, pág. 5, pl. IV,2. Otra representación dudosa de Perseo y Andrómeda recoge el LIMC I, "Andrómeda I", $n^{\circ} 43$, basándose en la cita de G. Ch. PlCARD, Le couronnement de Vénus, MEFR LVII-LVIII, 1940-1946, pág. 83, nota 9, como procedente de Oudna. 


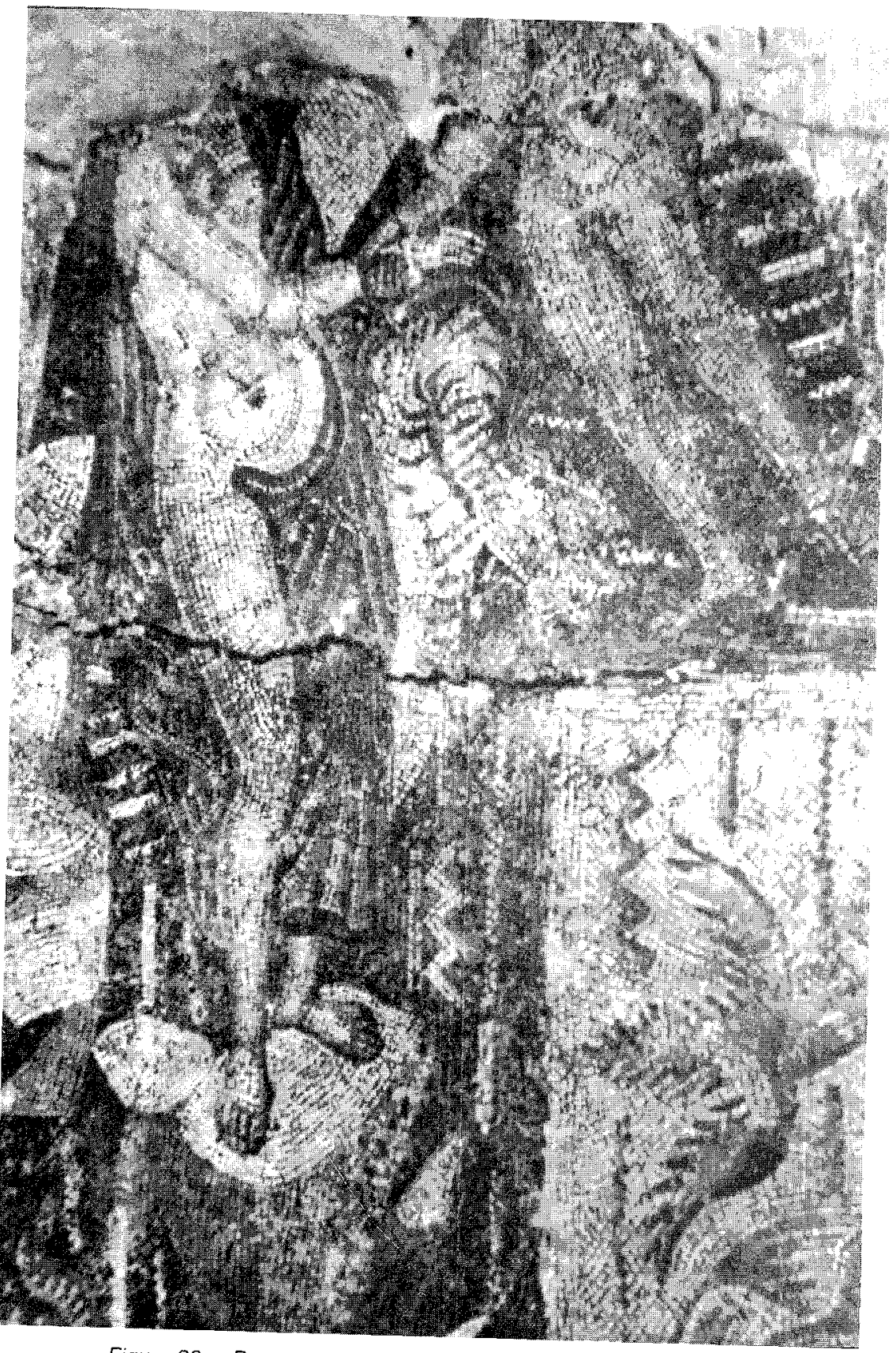

Figura 28. Perseo liberando a Andrómeda. Mosaico de Djemila. 
La nota más destacable en la representación de este momento del mito de Perseo es que sigue el modelo clásico de un cuadro de Nikias descrito por Plinio (NHXXV 132), repetido varias veces en pinturas de Herculano y Pompeya, donde el episodio de la liberación de Andrómeda gozó de un gran éxito (Fig. 29). El pintor ateniense, de época tardoclásica, se caracterizaba por el estilo sintético que impregnaba a todas sus representaciones de los mitos clásicos. Como dice Valeria Sampaolo uriducendo all'essenziale il paessagio circostante e sintetizzando attraverso i gesti e le espressioni dei personaggi la situazione vista non più nel suo svolversi, ma nel momento risolutivo non meno carico di tensione sicologica" ${ }^{41}$. En este episodio, como en la muda contemplación de Andrómeda por Perseo y en el de la íntima conversación entre ambos, el carácter erótico de la escena se acentúa con la habitual desnudez de la joven que con gesto recatado intenta, en la mayoría de los casos, cubrir su cuerpo, elevando aún más el grado de erotismo.

En cuanto a los tipos utilizados para representar a Perseo y Andrómeda, no hay duda de que el héroe no es más que una adaptación del tipo bien conocido de Hermes del siglo iv a.C. Para la figura de Andrómeda D. Levi distingue dos modelos, uno, el de la joven vestida con chiton de las pinturas romanas, estaria inspirado en el tipo neoático de la ménade danzante, cuyo origen remonta al arte griego como las figuras de la Nike de la Balaustrada; el otro, Andrómeda casi desnuda con el cuerpo flexionado en actitud pudorosa, que es el típico de los mosaicos, parece ser una creación original romana derivada del tipo de la Terpsícore del grupo de las Musas atribuido a Philiskos ${ }^{42}$.

Un posterior momento del mito, desconocido en la literatura pero que, siguiendo un modelo pictórico tardo-helenístico, gozó de una gran predilección en el arte romano por su carácter idílico y romántico, muestra a Perseo y Andrómeda reflejando la cabeza de la Medusa en el agua. El modelo iconográfico, que remonta a comienzos del siglo iv, se documenta en frescos (Fig. 30), camafeos y lucernas del siglo I d.C. y perdura en mosaicos de la baja antigüedad que, de $\epsilon$ sta forma, se convierten en los ejemplos más tardíos ${ }^{43}$. En la musivaria romana esta composición se representó solamente en el mosaico de Brading, fechado en el siglo IV d.C., y probablemente en el panel central del citado corredor de la Casa de Dionisos y Ariadna en la villa constantiniana de Antioquía. El cuadro de la villa romana

\footnotetext{
41 Cf. Romana Pictura. La pittura romana dalle origini all'età bizantina, Catalogo della Mostra (Rimini 1998) a cura de A. Donati, Electa 1998, pág. 301, $\mathrm{n}^{\circ} 88$.

42 D. LEVl, Antioch Mosaic Pavements, Princeton 1947, págs. 152-154.

43 LIMC I, «Andromeda l», núms. 102-123; LIMC VII, «Perseus», núms. 224-228.
} 


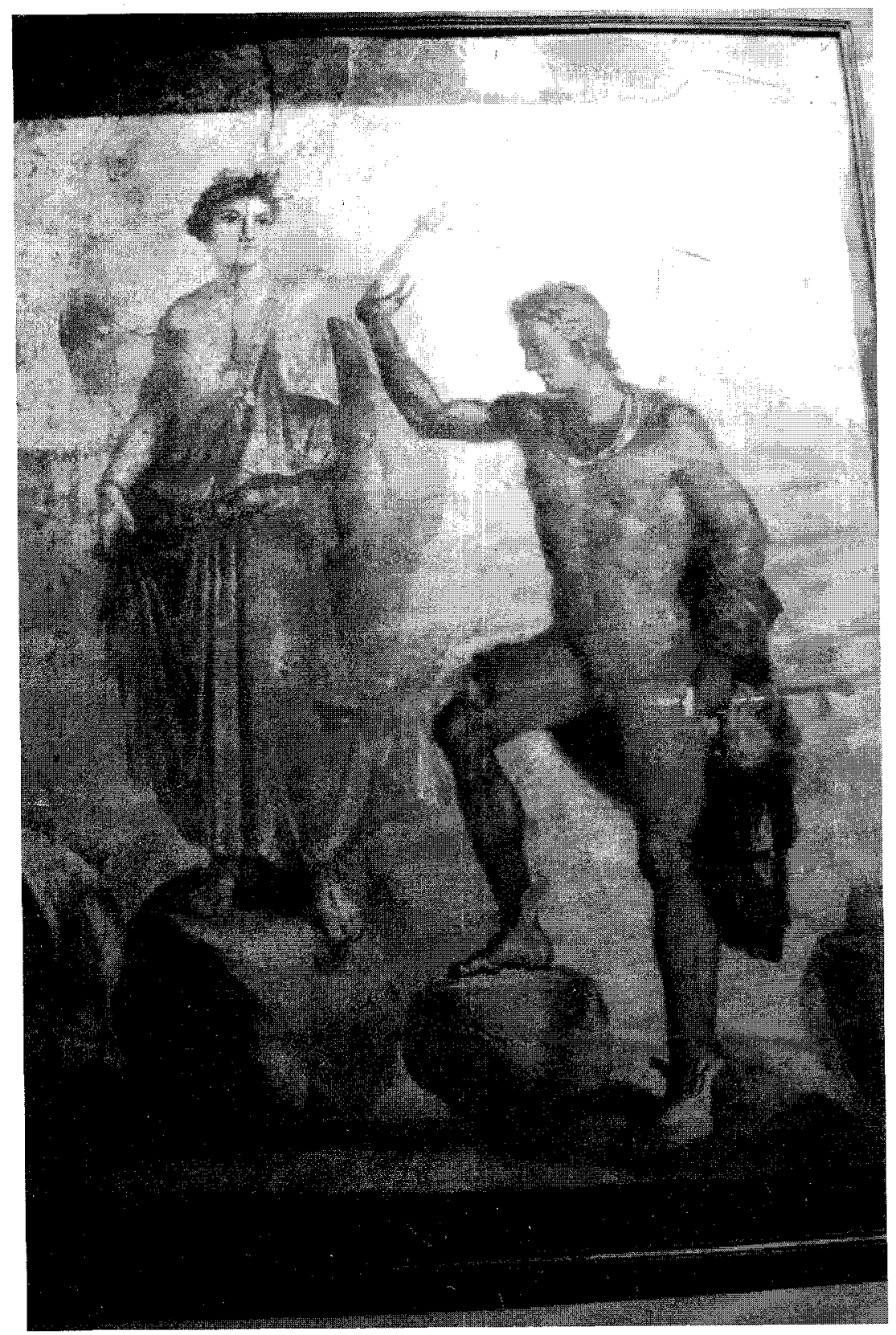

Figura 29. Perseo liberando a Andrómeda. Pintura de Pompeya. Foto G. López Monteagudo. 


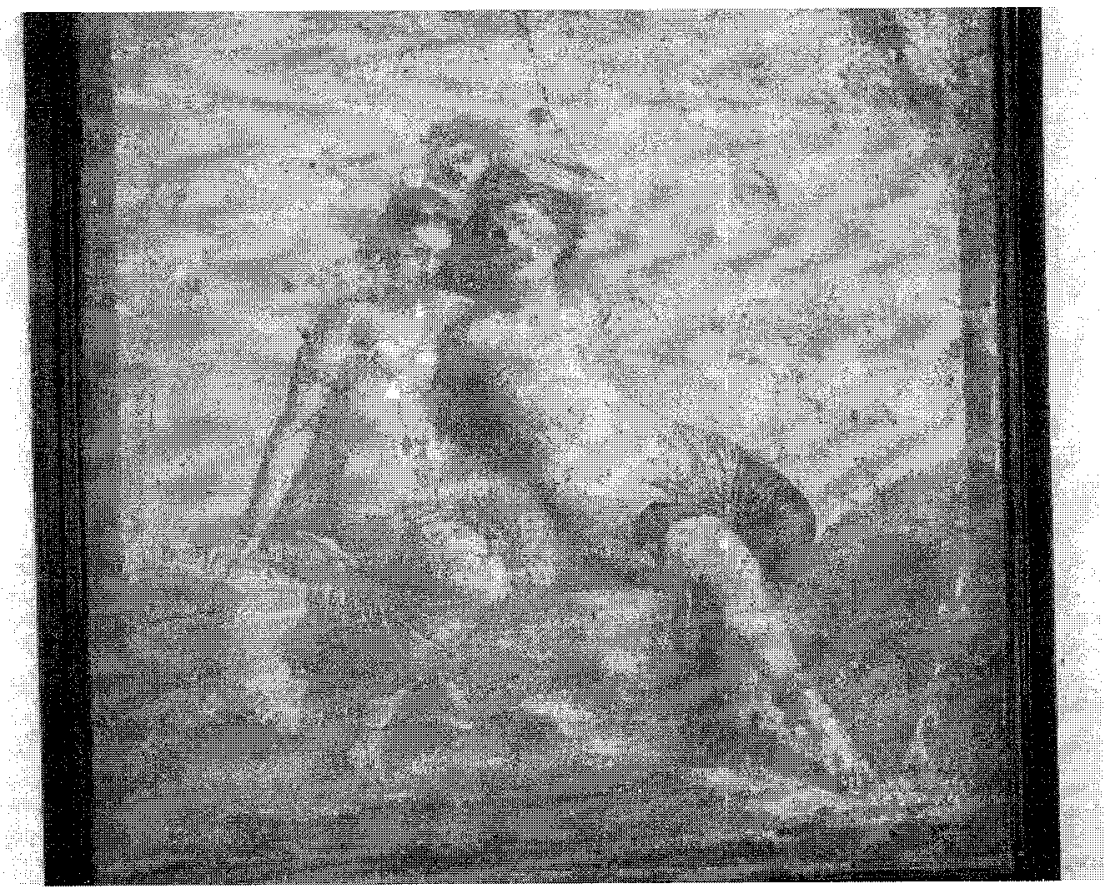

Figura 30. Perseo y Andrómeda reflejando el gorgoneion en el agua. Pintura de la Casa de los Capiteles colorados, en Pompeya. Foto G. López Monteagudo.

de Brading (Fig. 31) formaba parte de las escenas mitológicas y dionisiacas que decoraban el pavimento de la habitación bipartita núm. XII, dispuestas las de la parte inferior en torno a la cabeza de Medusa (vid. infra), con un panel central en el que se ha figurado a uno de los sabios, junto a un reloj de sol y una clepsydra, señalando con un puntero a la esfera ${ }^{44}$.

El pavimento de Antioquía constaba de siete cuadros, de los que solo se han conservado completos el de lá liberación de Andrómeda por Perseo (vid. supra), otros dos con parejas de sátiro y bacante, y parte del central muy destruido, que D. Levi identifica como Perseo y Andrómeda sentados en la roca contemplando la cabeza de la Medusa reflejada en el agua, basándose en los restos de la figura femenina que aparece reclinada en una

${ }^{44}$ R. LING, Brading, Brantingham and York: a New Look at Some Fourth-Century Mosaics, Britannia 22, 1991, págs. 148-149, PI. XV. Sobre la representación del sabio, cf. G. Lóez MoNTEAGudo, Termas y tecnología de las aguas. Testimonios musivos, Termalismo Antiguo. / Congreso Peninsular, Madrid 1997, págs. 463-464, Fig. 21 


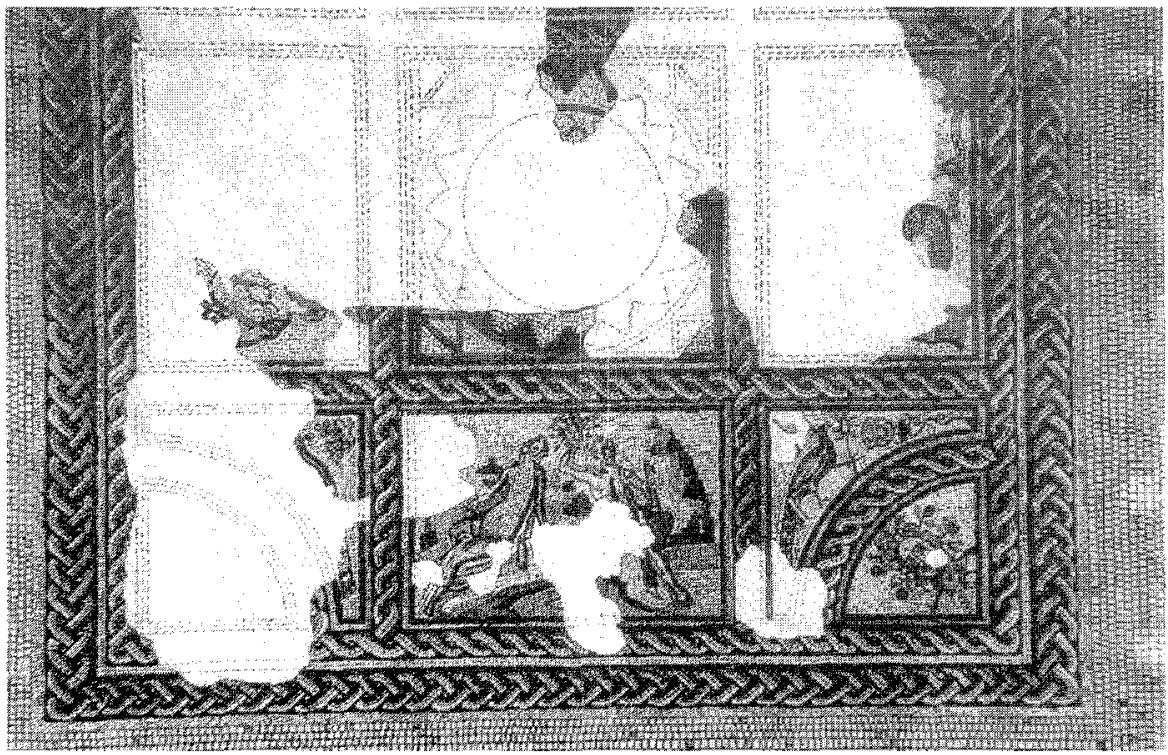

Figura 31. Perseo y Andrómeda reflejando el gorgoneion en el agua. Mosaico de Brading.

roca con la cabeza apoyada en la palma de su mano izquierda; la presencia del pedum en la mano derecha acentuaría, junto a las figuras de sátiros y bacantes de los otros paneles, el carácter báquico de Perseo y Andrómeda como miembros del thiasos dionisiaco (Fig. 32) ${ }^{45}$. A.J. Beeson piensa que la escena ha de interpretarse como Ariadna abandonada ${ }^{46}$.

L. Balensiefen denomina a esta composición iconográfica la «variante Andrómedas, en la que la joven, sentada, sustituye a la figura estante o sentada de la diosa en la «variante Athenea» (Fig. 33), adquiriendo la escena un marcado carácter erótico. Sin embargo, ninguna de las dos variantes iconográficas - Perseo y Andrómeda reflejando el gorgoneion en el agua, Athenea y Perseo contemplando la cabeza de la Medusa reflejada en el agua o en el escudo de la diosa - tienen una correlación literaria, remontando los primeros ejemplos a comienzos del siglo Iv a.C. Según esta autora, hay una diferencia de simbolismo entre el reflejo de la gorgona en el escudo de Athenea, cuando Perseo le da muerte, y la posterior contemplación de la cabeza por Athenea y Perseo bien en el escudo, bien en

45 D. LeVI, Antioch Mosaic Pavements, Princeton 1947, págs. 150-156, Fig. 58, Pl. XXIX b-c.

46 A.J. BEESON, Perseus and Andromeda as lovers. A mosaic panel from Brading and its origins, Mosaic 17, 1990, págs. 13-17. 


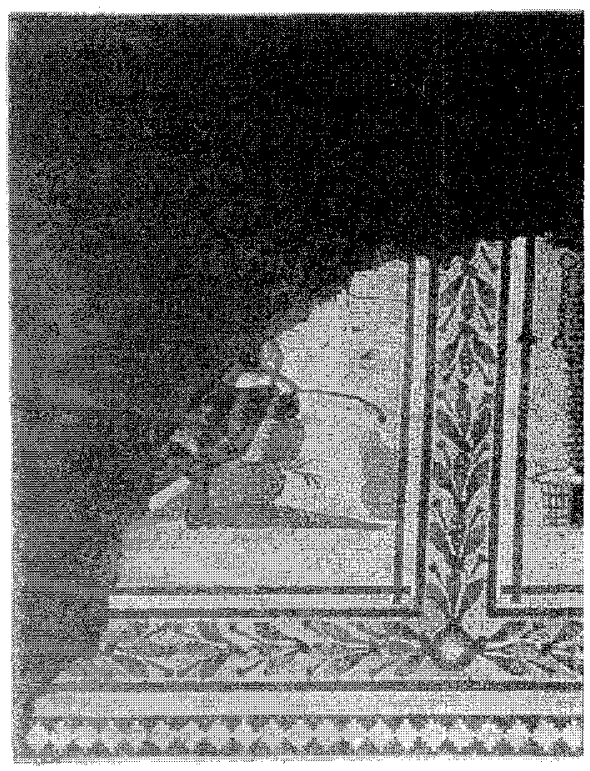

Figura 32. Perseo y Andrómeda reflejando la cabeza de la medusa en el agua. Mosaico de Antioquía.

el agua, o por Andrómeda y Perseo en el agua, ya que el primero constituye un motivo dramálico con una función narrativa, mieniras que el segundo sipone una pausa, una escena de tranquilidad antes de acometer las siguienies aventuras o de regresar felizmente a la patria. La diferencia estriba también en que el primero es una escena concreta, un momento corto en la vida de Perseo; por ol contrario, el segundo tiene un significado absoluto ya que la contemplación de la gorgona es una forma de mosirar el triunfo tola! de Perseo sobre la Medusa, porque ella no solo está ya muerta, sino que con su muerte él puede vencer sus maléficos poderes mágicos ${ }^{47}$.

Precisamente la representación de la cabeza de la Medusa, por su valor profiláctico o simplemente decorativo, pasó a ser uno de los temas favoritos de los mosaicos, en los que Iradicionalmente ocupa, como elemento dominante, el centro de una composición circular o cuadrangular, siendo los ejempios más tempranos los pavimentos griegos de Sycion y Eretria, que se datan

47 L. BALENSIEFen, Die Bedeutung des Spiegelgebildes als ikonographisches Motiv in der antiken Kunst, Tübingen 1990, págs.124-130. 


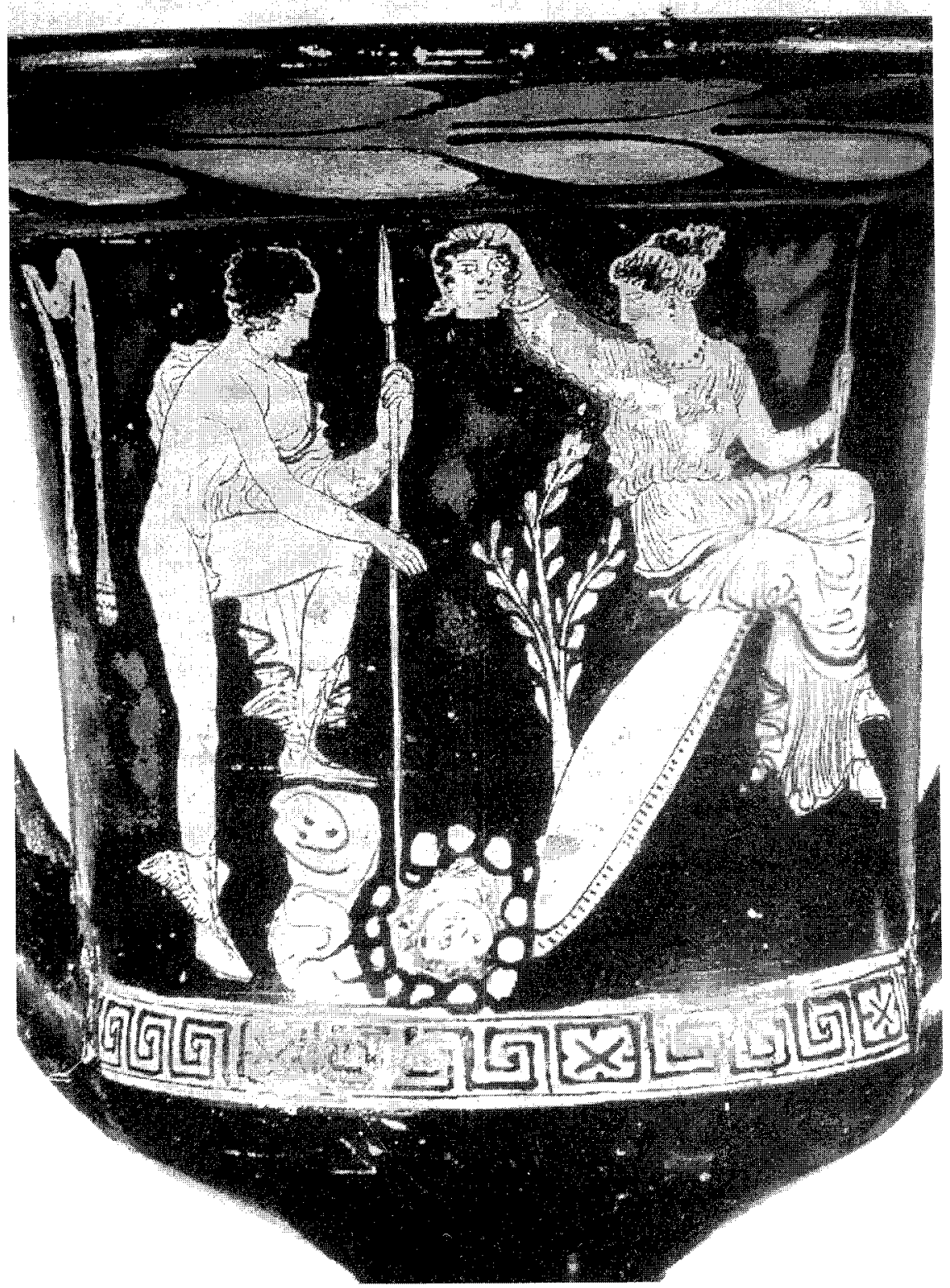

Figura 33. Athenea y Perseo reflejando la cabeza de Medusa en el agua. Crátera apulia. 
a comienzos del siglo IV a.C. ${ }^{48}$. Sin embargo, entre las numerosas representaciones de la Medusa en la musivaria romana hay que destacar la variante que la muestra dentro de un escudo de escamas bipartitas o de triángulos curvilíneos que, quizás, hace alusión al episodio contado por algunos autores, según el cual Perseo, tras realizar sus hazañas, entregó la cabeza de la Medusa a la diosa Athenea que la colocó en la égida (Hom. II. V 738-742; Eur. Ion 987-999; FHG I, fr. 26; Diod. III 70,5; Paus. IX 442-444; Sil. IX 442-444; Lucan. phars. IX 655-658; Erastosth. cat. XXII 20-25; Ov. met. IV 791-803) o en su escudo (Eur. el. 1255-1257; Apollod. bibl. II 46; Claud. cons. Stil. 24.128) y así aparece en las representaciones de la diosa ya en el siglo $v$ a.C., siendo los mosaicos de Egipto (Alejandría) y Libia (Ptolemais), de estilo típicamente ilusionista, los documentos más antiguos, puesto que se fechan al final del periodo helenístico o en época augustea ${ }^{49}$. En estos casos la cabeza de la Medusa no sería ya solo un objeto apotropáico contra las fuerzas del mal, sino que pasaría a utilizarse como símbolo globalizador del mito, sobre todo en aquellos lugares en los que su conexión con las hazañas de Perseo puede establecerse a través de otros mosaicos o de los programas iconográficos, como ocurre en Esparta, Tarragona, Thina, Bulla Regia, Brading, Palmyra y Antioquia, lugares que han proporcionado imágenes de diversas fases del mito.

El gorgoneion preside la composición en catorce pavimentos procedentes de Grecia, ocupando cinco de ellos el centro de un "escudo» circular compuesto por bandas de triángulos: villa de Dionisos en Knossos, datado en el siglo II d.C., con los bustos de las estaciones en los ángulos del cuadrado; El Pireo, de la misma fecha (Fig. 34); dos de Patras, uno hallado en el triclinio de una villa romana; y Thasos, posterior a la segunda mitad del siglo II d.C. La variante de semi-escamas radiales aparece en Grecia por primera vez en el siglo III d.C., en los mosaicos de Kos (Fig. 35) y villa romana de Naoussa, y perdura hasta el siglo VI en el pavimento de una casa excavada en Megalópolis. El caso de Esparta es particular, ya que ha dado, además del citado mosaico de Perseo matando a la Medusa (vid. supra), tres pavimentos decorados con el gorgoneion. Uno de ellos, perteneciente a la variante de escamas bipartitas, con una cronología en la

48 A. Panagiotopoulou, Représentations de la Méduse dans les mosaïques de Grèce, VI CIMA, Guadalajara 1994, págs. 369-382, Figs. 1-3; LIMC IV, "Gorgo, Gorgones", núm. 224, ejemplar de Alejandría; ID., "Gorgones Romane", núms. 10-13, 16-17, 19-24, 123, 131, 148 y 175-177, mosaicos de Pompeya, Marsala, Ostia, Rímini, Antioquia, Esparta, Palencia, Dar Zmela, Tarragona, Thina, Bignor, Bonn, Antioquía, Tindari, Efeso, Rímini, Roma, Atenas y SaintRoman-en-Gal.

49 Cf. A.-M. Guimier-Sorbets, Les mosaĩques à la Méduse, en La gloire d'Alexandrie, Catálogo de la exposición (París, Musée du Petit Palais, 7 mai-26 juillet 1998), París 1998, págs. 291 293. 


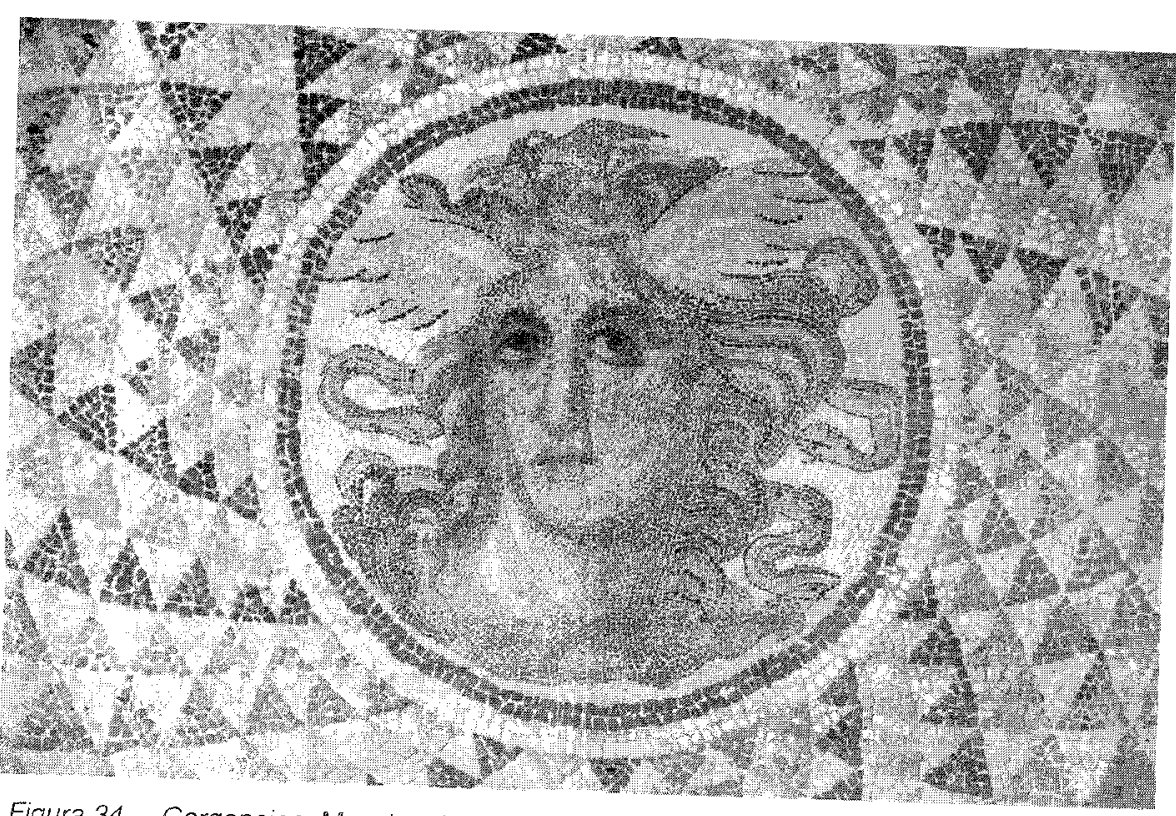

Figura 34. Gorgoneion. Mosaico de El Pireo. Museo de Atenas. Foto G. López Monteagudo.

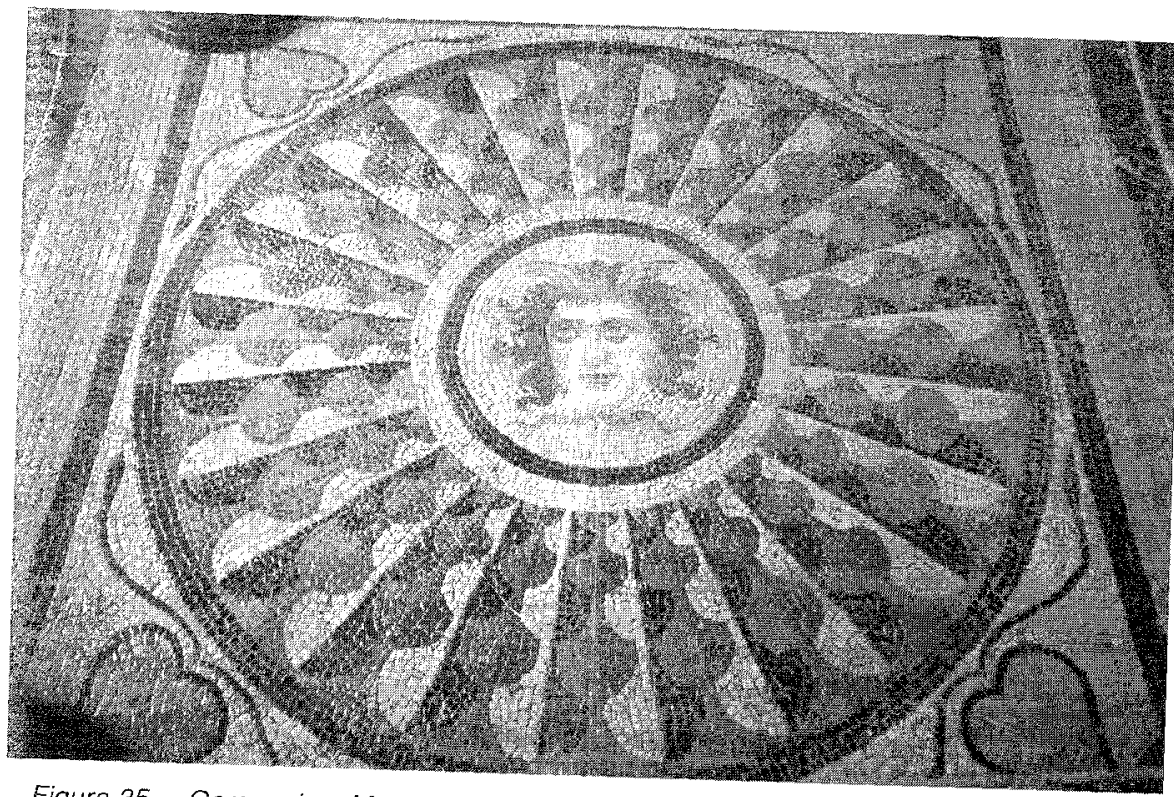

Figura 35. Gorgoneion. Mosaico de Kos. Museo de Rodas. Foio G. López Monteagudo. 
segunda mitad del siglo III d.C., ofrece la particularidad de presidir un verdadero escudo dividido en cuatro rectángulos curvilíneos (Fig. 36) ${ }^{50}$.

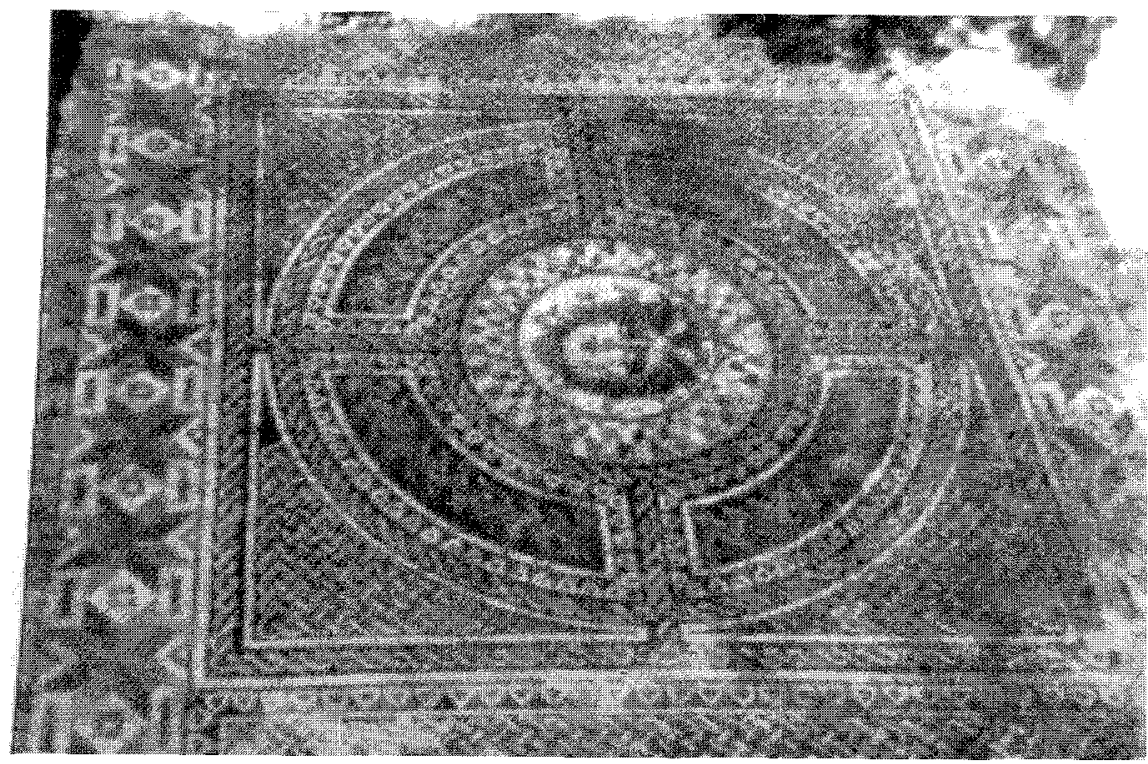

Figura 36. Cabeza de Medusa. Mosaico de Esparta.

En la musivaria hispana es frecuente la representación de la cabeza de la Medusa presidiendo el centro del pavimento ${ }^{51} \mathrm{y}$, concretamente, el tipo de composición formado por un escudo de triángulos curvilíneos a partir del gorgoneion central, que puede considerarse como alusión a la égida o al escudo de Athenea $y$, por consiguiente, enlazable con el mito de Perseo, se documenta en los mosaicos de Baétulo ${ }^{52}$, Carmona (Fig. 37) ${ }^{53}$ y Alcolea del Río ${ }^{54}$, con la particularidad de que los ángulos llevan respec-

50 A. Panagiotopoulou, Représentations de la Méduse dans les mosaïques de Grèce, VI CIMA, Guadalajara 1994, págs. 369-382, Figs. 4-12.

51 En total son once los mosaicos hispanos presididos por la cabeza de Medusa, sumando a los citados en el texto, los ejemplares de Itálica, Córdoba, Marbella, Balazote y Palencia, cf. CMRE X, 1989 , págs. 45-47, núm. 29, láms. 26, 45 y 47; M. DuRan, lconografía de los mosaicos romanos en la Hispania alto-imperial, Barcelona 1993, págs. 313-325.

52 M. DURÁN, lconografía de los mosaicos romanos en la Hispania alto-imperial, Barcelona 1993, págs. 256-257, no 72, lám. XL.

53 CMRE IV, 1982, págs. 31-34, n 15, láms. 11-12.

54 M.L. Neira Jiménez, Paralelos en la musivaria romana de Hispania y Grecia. A propósito de un mosaico de Alcolea del Río y un pavimento de Mitilene, Anales de Arqueología Cordobesa 9 , 1998, en prensa. Piensa la autora que, al igual que el hispano de Alcolea, el mosaico de Mitilene llevaría también en su centro la representación de la cabeza de Medusa. 


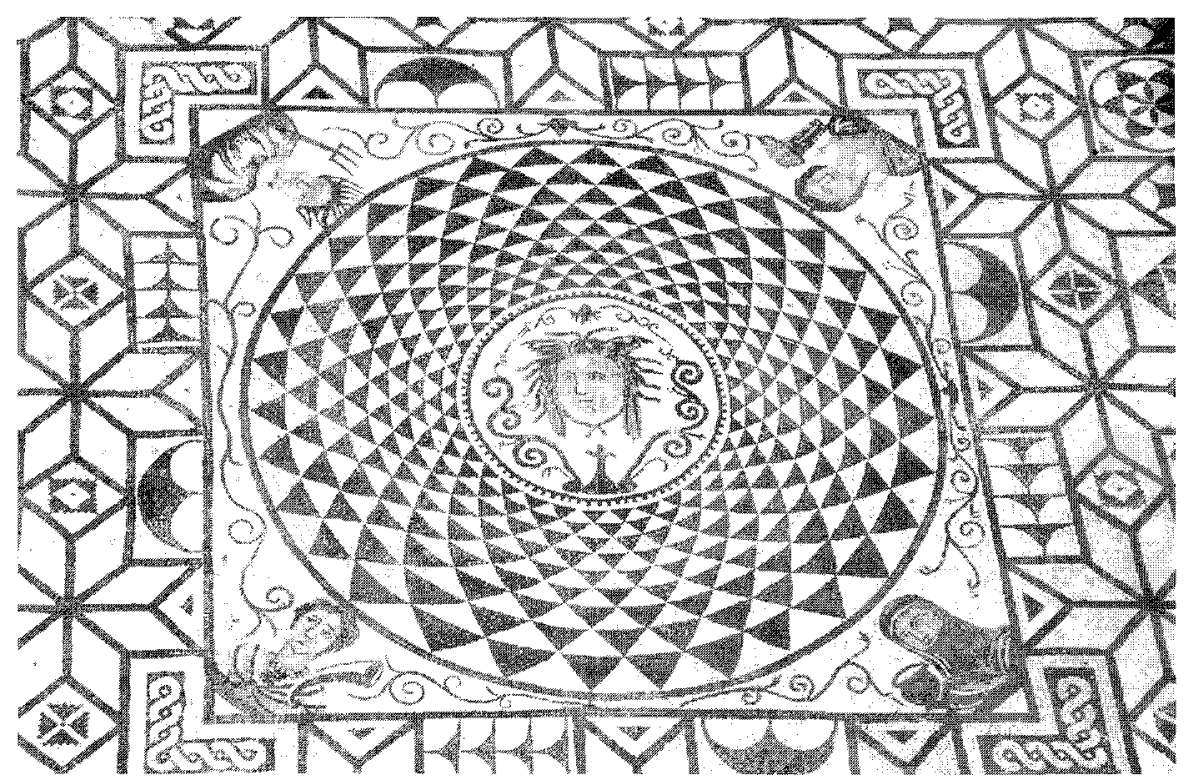

Figura 37. Gorgoneion. Mosaico de Carmona. Foto G. López Monteagudo.

tivamente delfines, bustos de las estaciones y tritones. La variante del gorgoneion en el centro de un escudo de semi-escamas radiales solo se documenta, de forma segura, en los ejemplares hispanos de Mérida y Tarragona. En el pavimento emeritense, que se fecha a fines del siglo 11 o comienzos el III, el octógono central va decorado con un escudo de medias escamas en torno a la cabeza de la medusa, que recuerda muy de cerca a los ejemplares de Esparta, tocada con alas y serpientes en el cuello, a partir del cual se desarrolla una composición ortogonal de meandros que intercalan cuadrados, rectángulos y hexágonos decorados con dos bustos dionisiacos, diversos pájaros y peces (Fig. 38) ${ }^{55}$. El mosaico fragmentario muy destruido de Tarragona, que se conserva en el Museo Arqueológico de esa ciudad, está compuesto por un panel cuadrangular pre-

55 CMRE 1, 1978, pág. 49, n57, láms. 88-89. Agradezco al Dr. J.M. Álvarez Martínez, director del Museo Nacional de Arte Romano de Mérida, la fotografía que amablemente me ha enviado para su publicación. La composición en "escudo de escamas» se documenta también en un pavimento procedente de Zaragoza, del siglo IV d.C., cf. D. FERnÁndez Galiano, Mosaicos romanos del convento Caesaraugustano, Zaragoza 1987, pág. 48, n²7, lám. XX, y en otro de la iglesia de Sta. María de Tarrasa, fechado en el primer tercio del V, cf. X. BARRAL I ALTET, LeS mosaïques romaines et médiévales de la regio Laietana, Barcelona $1978, n^{\circ} 144$, lám. XCl, aunque se ignora si en el centro, hoy perdido, se representaba el gorgoneion. 


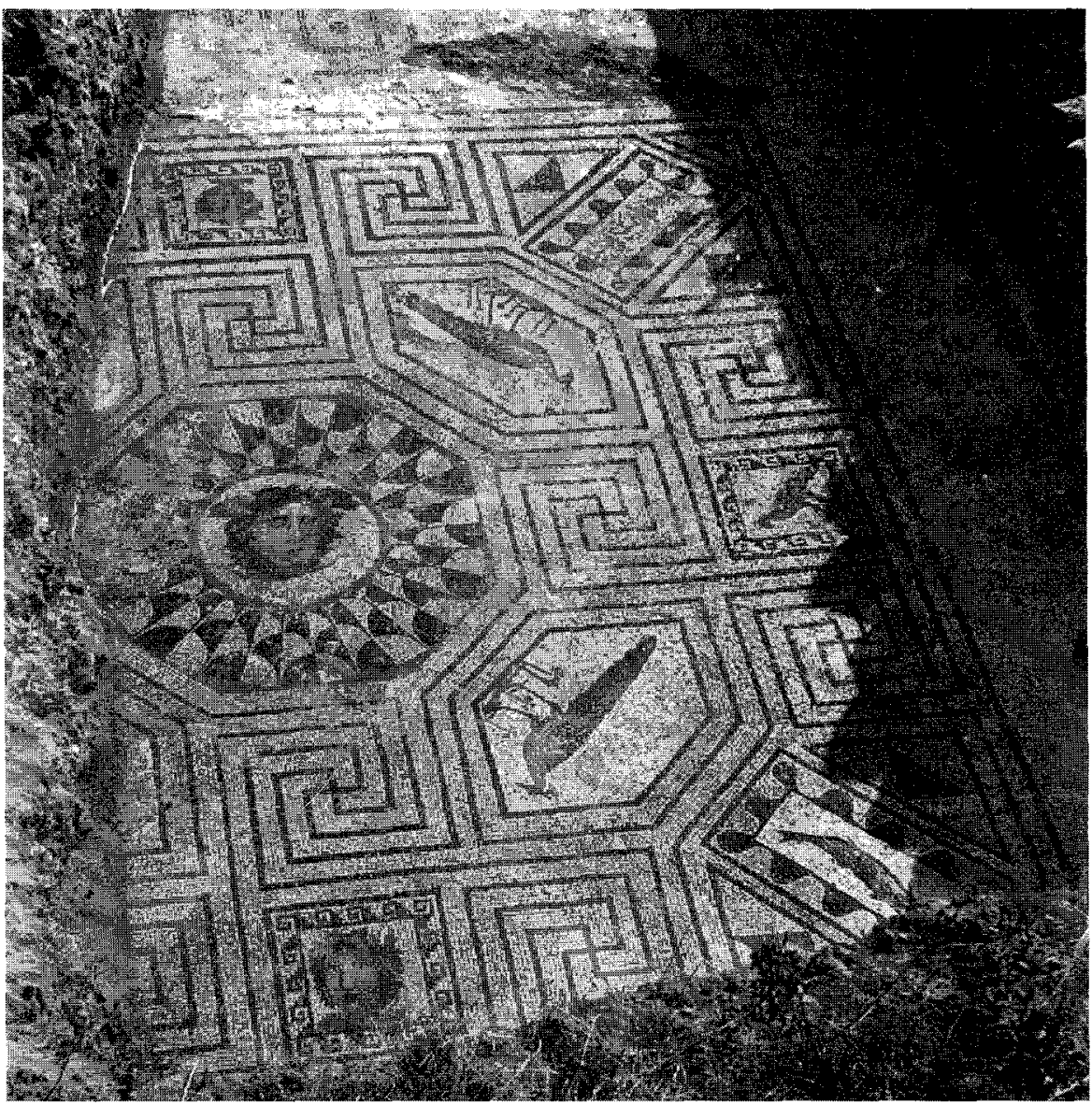

Figura 38. Gorgoneion. Mosaico de Mérida. Foto Archivo Museo Nacional de Arte Romano.

sidido por el medallón con la cabeza de Medusa, del que irradian las típicas líneas de semipeltas, y un rectángulo lateral con dos pavos reales afrontados en un campo cubierto de granadas (Fig. 39) ${ }^{56}$. Su relación di-

56 Puig I Cadalfach, L'Arquitectura romana a Catalunya, Barcelona 1934, pág. 361, lám. 478. Agradezco a la Prof. Dra. R. Navarro los datos que amablemente me ha proporcionado sobre este pavimento, que forma parte de su tesis doctoral sobre "Los mosaicos romanos de Tarragona» (Univ. de Barcelona 1980), en vías de publicación. 
recta con el mito de Perseo puede establecerse por proceder de la antigua Tarraco, lugar que ha proporcionado el mencionado pavimento de la liberación de Andrómeda (vid. supra) presidido por la cabeza de la Medusa (vid. infra).

En la musivaria del $\mathrm{N}$. de Africa la representación del gorgoneion en el centro de un "escudo de escamas", se reduce a los ejemplares tunecinos procedentes de los baños privados de Dar Zmela, de la segunda mitad del siglo II (?) (Fig. 40), Casa de las Musas de el Djem y habitación A 14 del caldarium de las Grandes Termas de Thina, fechados ya a fines del siglo III (Fig. 41) ${ }^{57}$. No obstante, su conexión con el mito de

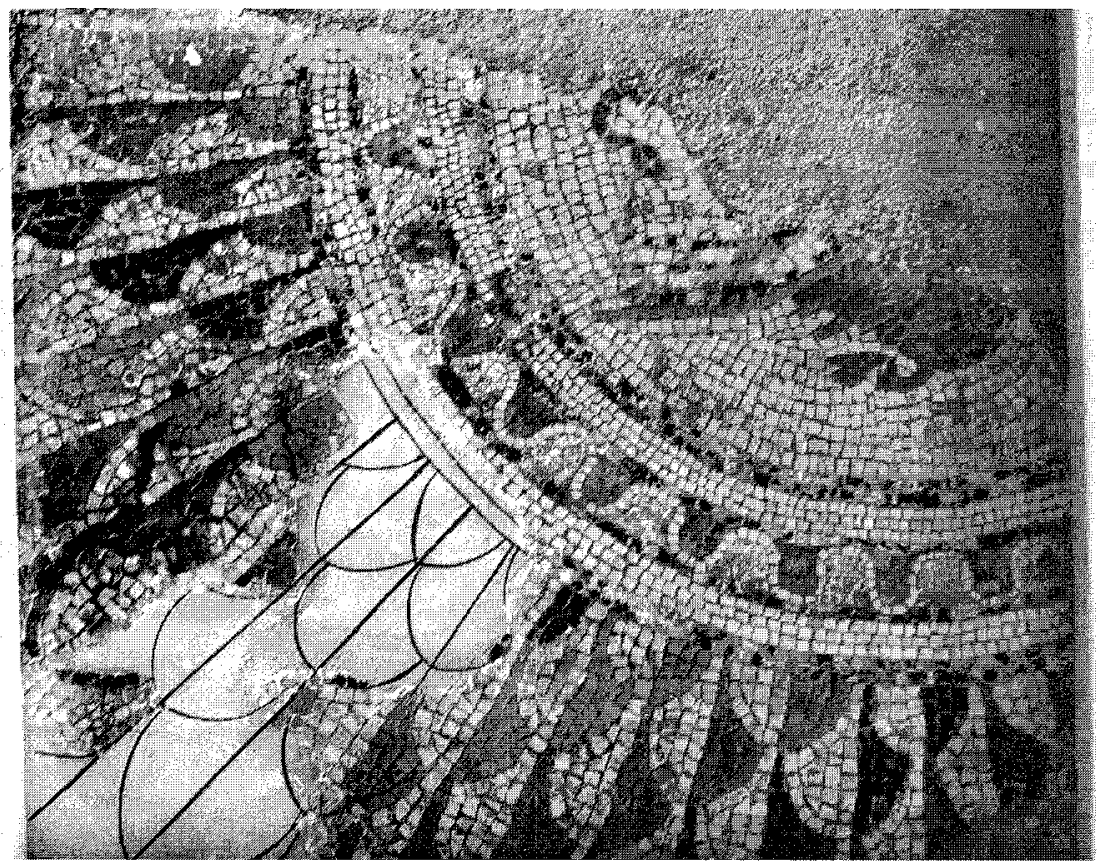

Figura 39. Gorgoneion. Mosaico de Tarragona. Foto G. López Monteagudo.

57 K.M.D. Dunbabin, The Mosaics of Roman North Africa, Oxford 1978, págs. 163 (n. 149), 258,271 y 273. El gorgoneion preside también los pavimentos norteatricanos de Mokenine, en el Museo de Sousse (ibid., p. 265) y Casa de Dionisos y las cuatro Estaciones de Volúbilis, del siglo III (ibid., p. 277). Una variante lo constituye el mosaico de Timgad, de ca. 200, en el que la cabeza de Medusa ocupa el centro de una composición lineal y no radial de escamas bipartitas, adaptada a un espacio semicircular, cf. S. Germain, Les Mosaïques de Timgad, Paris 1969, págs. 89-90, n²119, pl. XXXIX. 


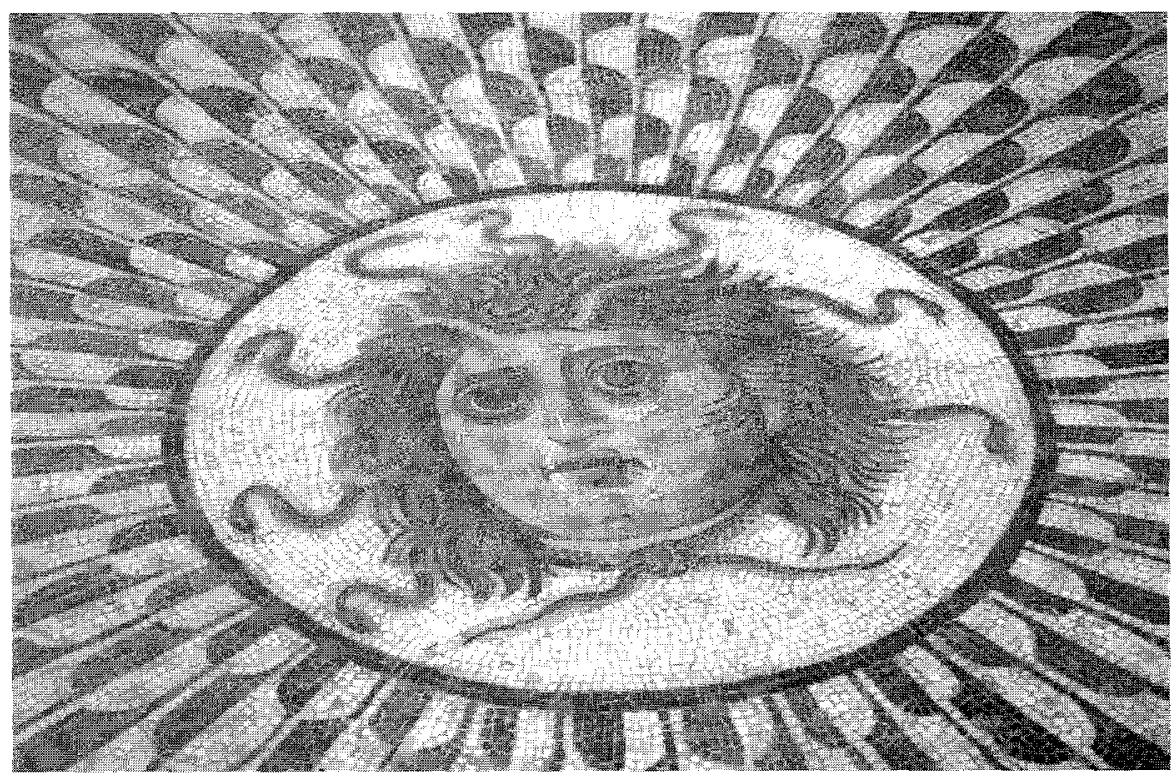

Figura 40. Gorgoneion de Dar Zmela, Museo de Sousse. Foto G. López Monteagudo.

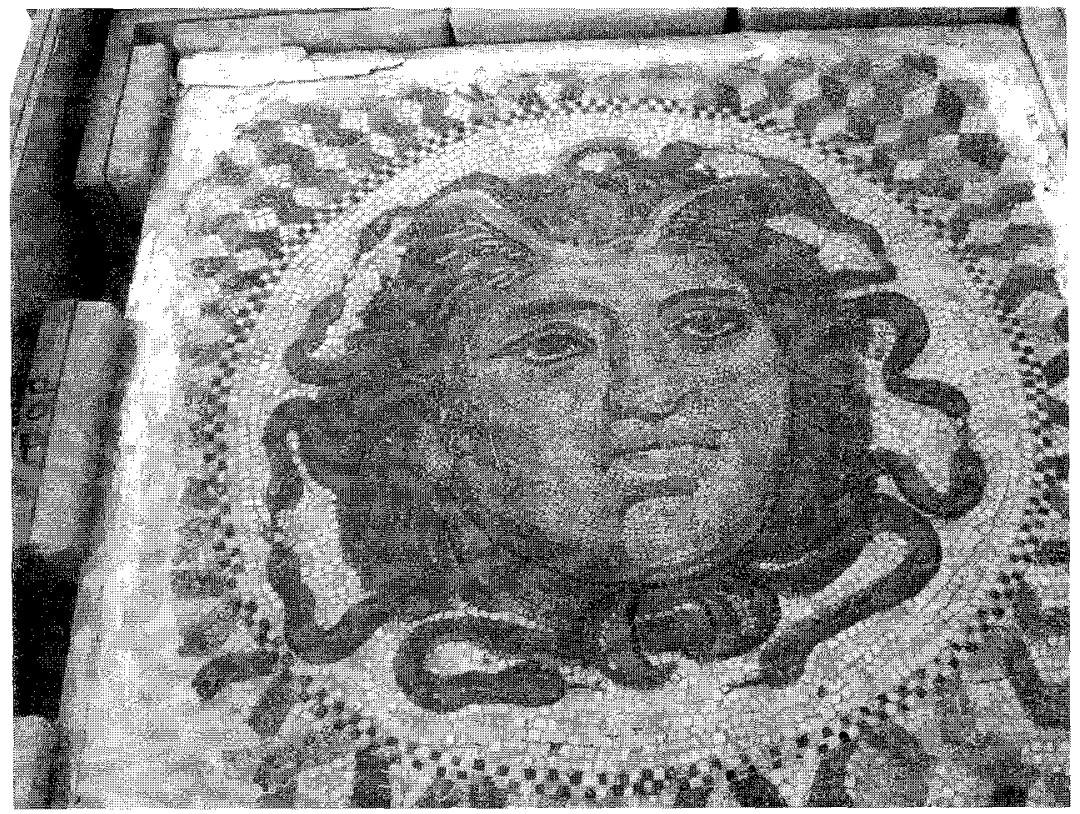

Figura 41. Cabeza de Medusa. Mosaico de Thina, Museo de El Djem. Foto G. López Monteagudo. 
Perseo solamente está clara en los pavimentos de Thina ${ }^{58}$ y del Museo. de Bulla Regia (Fig. 42) ${ }^{59}$. En estos lugares la presencia de escenas que ilustran las fases del mito referentes a Dánae arribando en el cofre a la isla de Seriphos y Perseo liberando a Andrómeda (vid. supra), inducen a establecer una relación con las representaciones de la Medusa, aunque procedan de distintos espacios arquitectónicos. Dentro de esta misma línea de conexión temática habría que situar los pavimentos de Antioquía: Perseo liberando a Andrómeda, procedente de la Casa de Dionisos y Ariadna, y el gorgoneion de la habitación $n^{\circ} 5$ de la Casa del Pavimento rojo (Fig. 43) ${ }^{60}$; y de Palmyra: cabeza de Medusa de la Casa de Aquiles (Fig. 44) y mosaico de Cassiopea de la Casa del mismo nombre ${ }^{61}$.

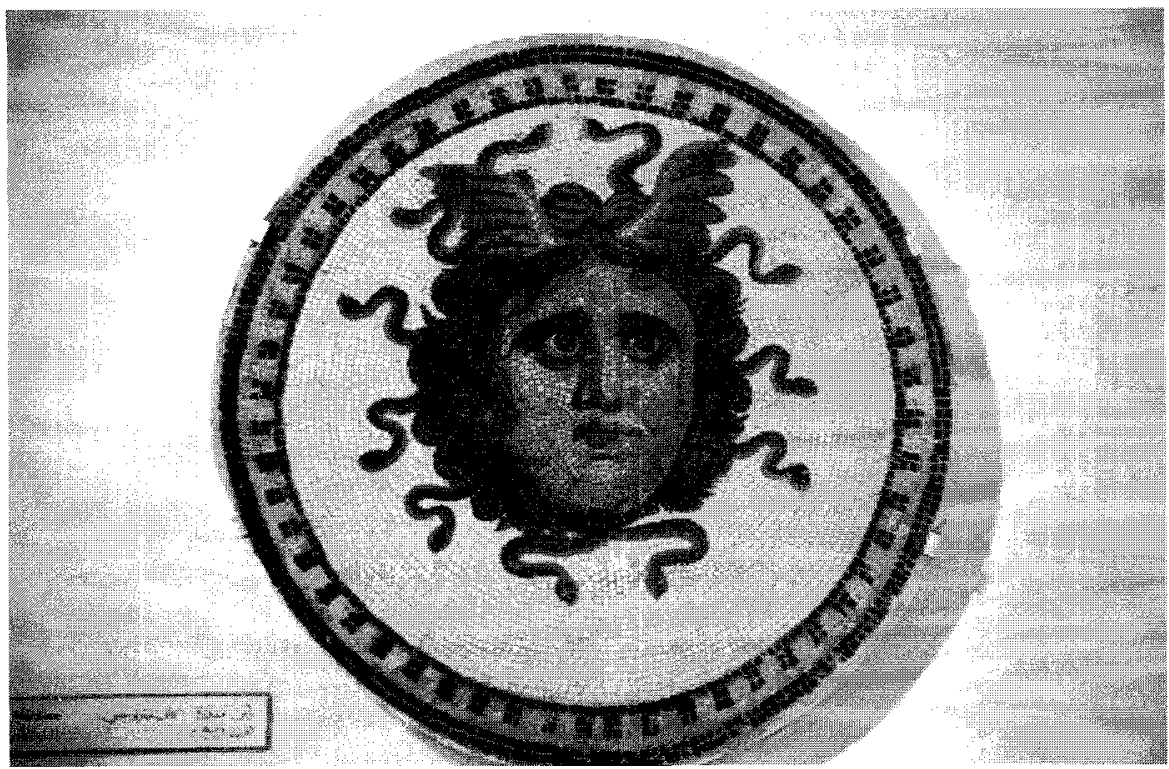

Figura 42. Cabeza de Medusa. Mosaico de Bulla Regia. Foto G. López Monteagudo.

58 R. Massigli, Musée de Sfax, Paris 1912, pág. 6, núm. 23; M. YaCoub, Guide du Musée de Sfax, Tunis 1966, pl. XV,1

59 Inédito (?), conservado en el Museo de Bulla Regia.

60 D. LEVI, Antioch Mosaic Pavements, Princeton 1947, págs. 150-156, 384-386, pl. XXIX b-C, XCVI a.

61 H. Stern, Les mosaïques des maisons d'Achille et de Cassiopée à Palmyre, París 1977, págs. $23-24,30-36$, figs. 36 y 44 


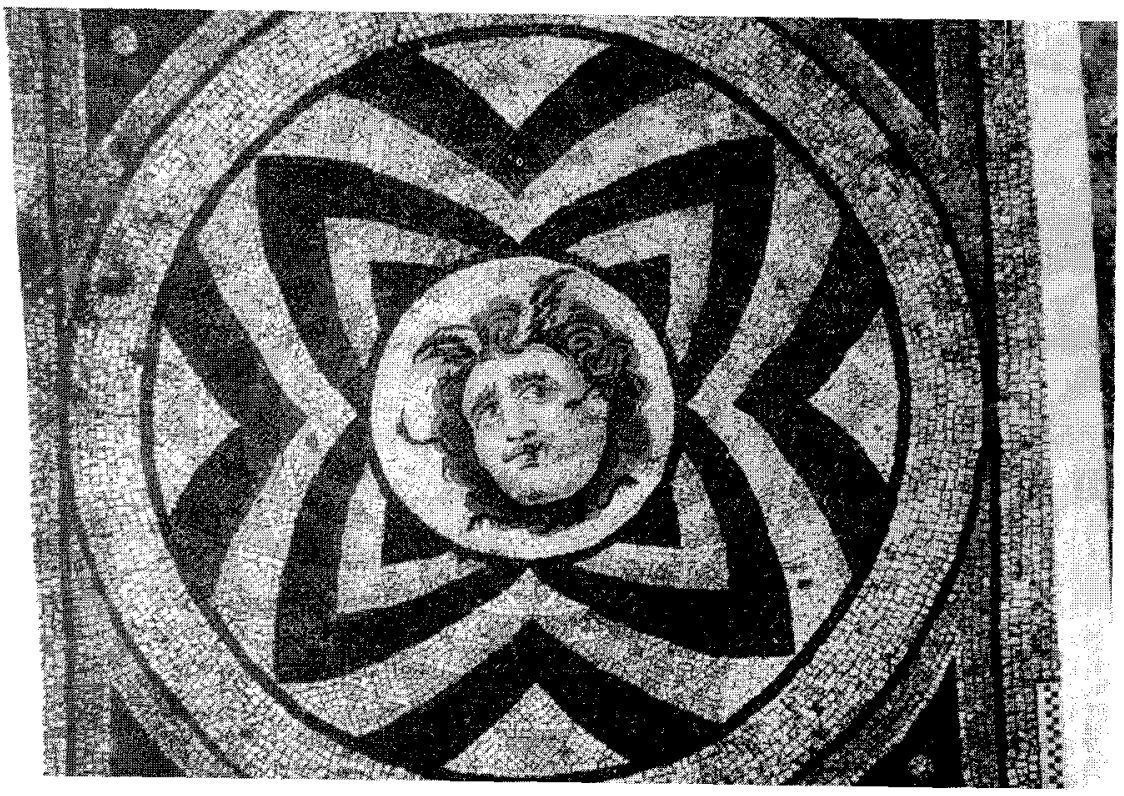

Figura 43. Cabeza de Medusa. Mosaico de la Casa del Pavimento rojo, en Antioquía.

Un caso excepcional lo constituyen los mosaicos de Tarragona y Brading, en los que la cabeza de la Medusa, carente de los detalles iconográficos que la conectan con el escudo o la égida de Athenea, se halla sin embargo claramente en relación con el mito de Perseo a través del resto de la decoración del pavimento. En el mosaico hispano de Tarragona (Fig. 45), de época severiana, el gorgoneion ocupa el centro de una composición cuadrangular, cuyos ángulos van decorados con los bustos de las estaciones, rodeada de cuatro paneles rectangulares, de los que solo se ha conservado uno con la escena de la liberación de Andrómeda ( vid. supra) ${ }^{62}$. Llama la atención la caiidad artística de este emblema, en comparación con el panel de Perseo y Andrómeda, y el pathos que irradia la Medusa, solo comparable al que ofrece la gorgona del mosaico del Museo Nazionale de Roma, fechable hacia mediados del siglo II d.C. ${ }^{63}$. Idéntica

62 A. Balli, II mosaico "della Medusa» di Tarragona, Hommages à $M$. Renard, III (=col. Latomus $n^{\circ}$ 103), Bruxelles 1969, págs. 3-12, Tavv. I-lil. Según C. Mc Keon, el resto de los paneles de este mosaico irían decorados también con otros episodios del mito de Perseo, siendo muy probable que en uno de ellos se representara la decapitación de la Medusa, cf. A. Panaglotopoulou, Représentations de la Méduse dans les mosaïques de Grèce, VI CIMA, Guadalajara 1994, págs. 369-382, n. 33.

63 M.E. BLAKE,MAAR 13, 1936, págs. 82-83, Tav. 14,2. 


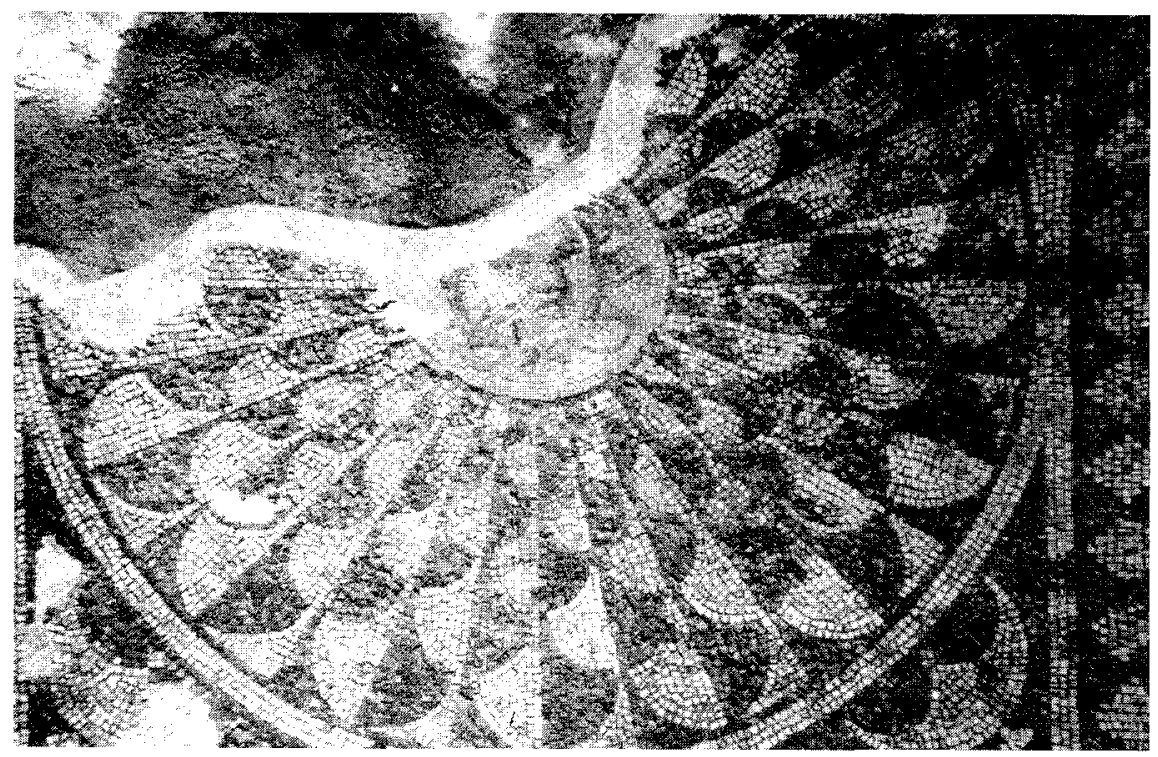

Figura 44. Cabeza de Medusa. Mosaico de la Casa de Aquiles, en Palmyra.

conexión se muestra en el mosaico de Brading entre la cabeza de Medusa (Fig. 46), que preside el pavimento de la habitación XII, y el panel en el que se representa a Perseo y Andrómeda sentados reflejando el gorgoneion en el agua (vid. supra) 64

Como colofón al idilio entre Perseo y Andrómeda, símbolo de la reconciliación conyugal, el arte romano figuró a la feliz pareja volando hacia Seriphos en una pintura pompeyana de la Casa de los Vetii (Fig. 47). La transformación de ambos personajes en constelaciones (Fig. 48) llevó a utilizar estos mitos con una idea de inmortalidad y ello explicaría su presencia en sarcófagos y en ambientes funerarios, como ocurre con la pátera portuguesa, porque la victoria de Perseo sobre el kethos y la Medusa, se asimila al triunfo del héroe sobre la muerte ${ }^{65}$.

64 R. LING, Brading, Brantingham and York: a New Look at Some Fourth-Century Mosaics, Britannia 22, 1991, págs. 148-149, PI. XV.

65 Sobre las ilustraciones estelares de Perseo y Andrómeda en miniaturas medievales, cf. E. Langlotz, Perseus, Heidelberg 1951; K.M. Philips, Perseus and Andromeda, AJA 72, 1968, págs. 15-23, pl. 16-20. I. Gómez de Liaño piensa que existe una cierta conexión entre Mitra y Perseo, partiendo de la base de que ambas representaciones celestes se hallan relacionadas con la constelación de Taurus y por tanto con el equinocio de la Primavera. Pero también iconográficamente ambos personajes portan el gorro frigio y los dos apartan la mirada de sus víctimas en el momento 


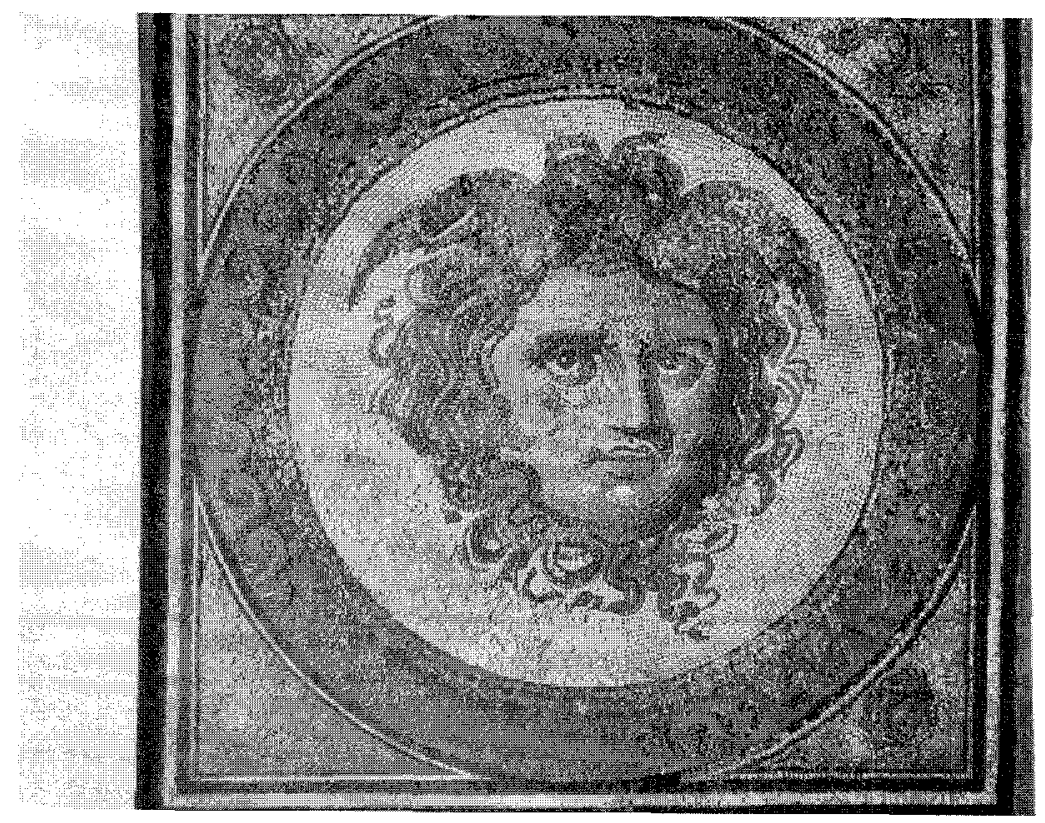

Figura 45. Cabeza de Medusa. Mosaico de Tarragona.

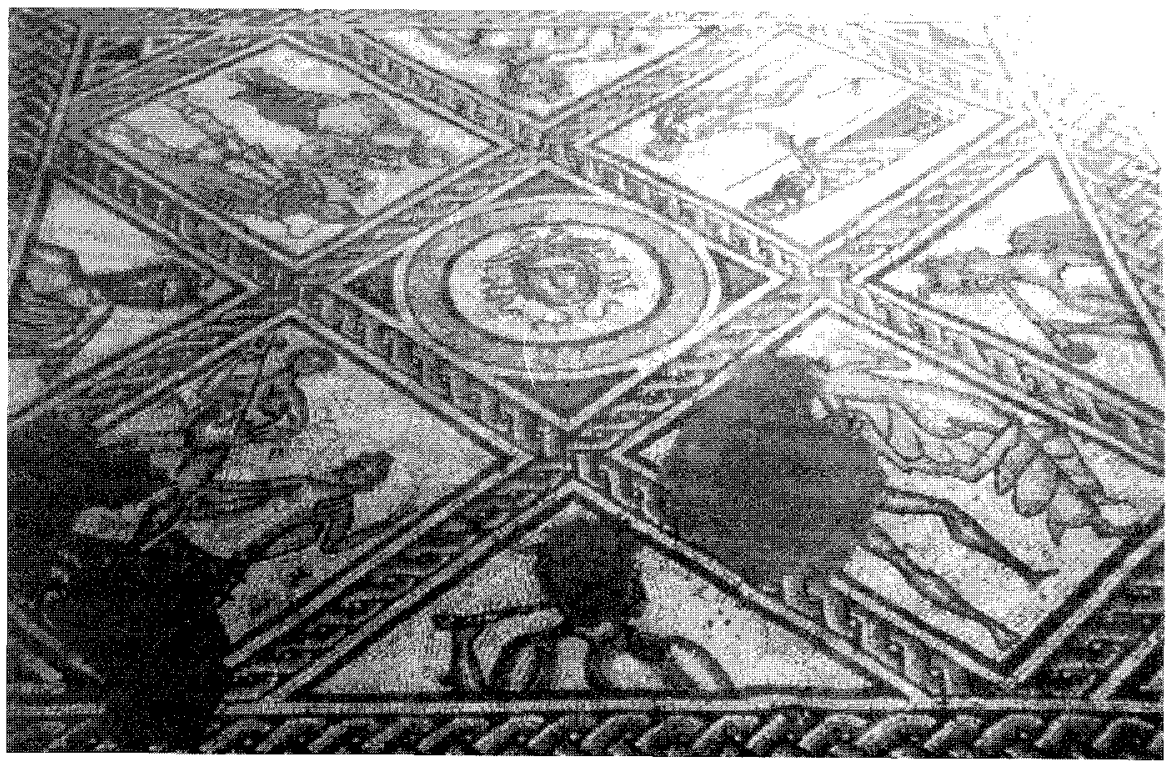

Figura 46. Cabeza de Medusa. Mosaico de Brading. 


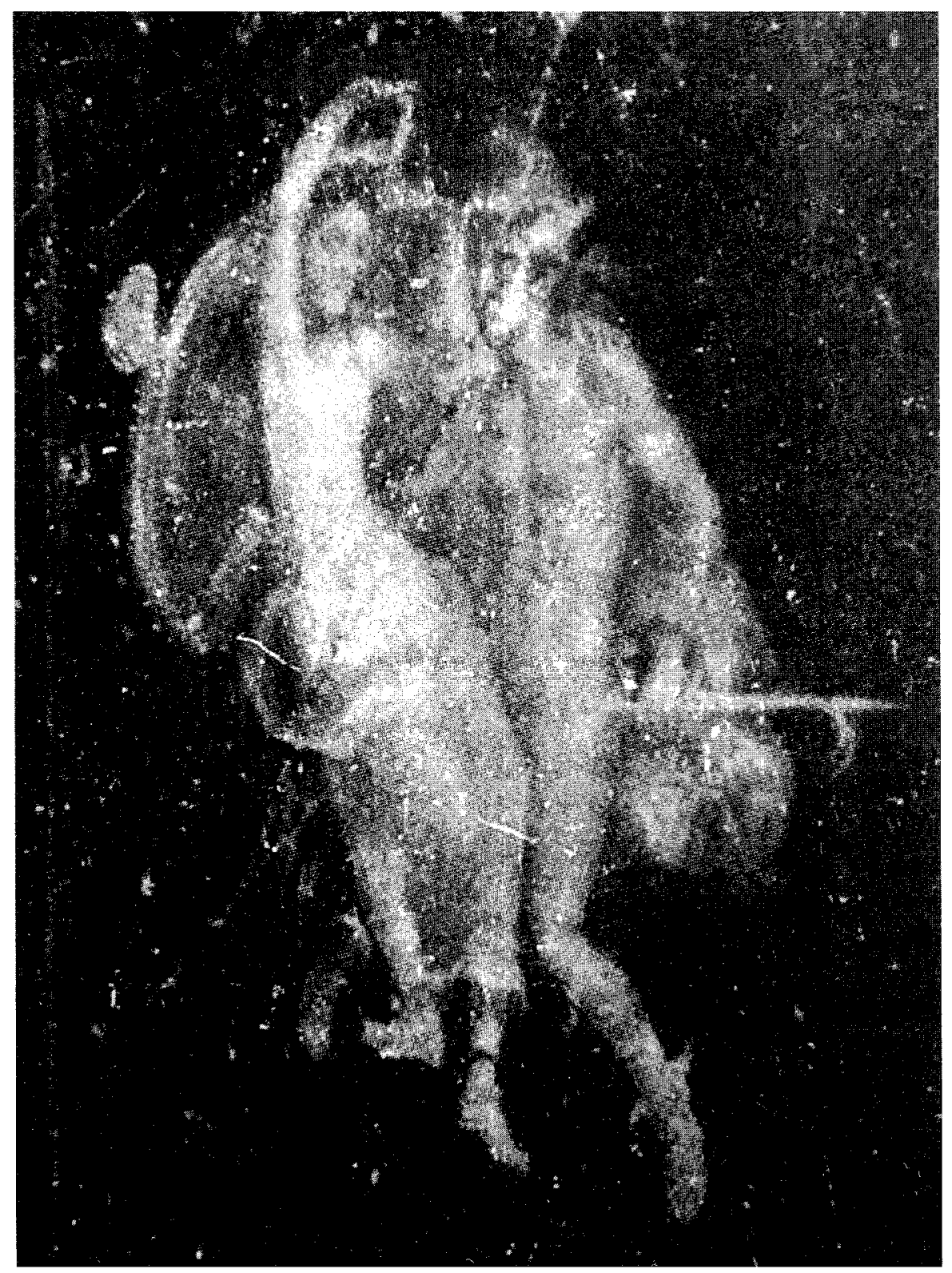

Figura 47. Perseo y Andrómeda volando hacia Seriphos. Pintura de la Casa de los Vetii, en Pompeya. 
En general puede decirse que, entre las escenas dedicadas a la mitología, la musivaria romana ha proporcionado escasos documentos relacionados con el mito de Perseo, a excepción de las representaciones de la cabeza de Medusa que son bastante numerosas. Los episodios más representados fueron el de Dánae recibiendo la lluvia de oro, que se figuró en los pavimentos de Itálica, Beyrouth, Cartago, Ouled Agla y Palermo, y el de la liberación de Andrómeda, que, con sus variantes iconográficas, se documenta en los mosaicos de Conímbriga, Trier, Palmyra, Tarragona, Bulla Regia, Djemila, Thina (?) y Antioquía, mientras que la otra creación artística romana - Perseo y Andrómeda reflejando el gorgoneion en el agua - solamente se figuró en los pavimentos de Brading y Antioquía, documentándose una sola vez la decapitación de la Medusa en el mosaico de Esparta y la llegada de Dánae y Perseo a Seriphos en el pavimento de Thina.

En Hispania la representación del mito de Perseo se reduce a los pavimentos de Itálica, Conímbriga y Tarragona, en cada uno de los cuales se plasmó un episodio diferente - Dánae recibiendo la lluvia de oro, Perseo con la cabeza de la Medusa en la mano y el kethos a sus pies, Perseo contemplando a Andrómeda - sin contar las seis veces que aparece la Medusa en relación directa con el mito o en el centro de un "escudo» de triángulos curvilíneos y de escamas. Sin embargo, y a excepción de Dánae recibiendo la lluvia de oro en presencia de Júpiter, iconografía que se aproxima a la del pavimento de Cartago, las otras dos escenas hispanas ofrecen unas particularidades tanto en la elección de los episodios, como en el tratamiento iconográfico y en el contenido alegórico de los mismos, que los diferencia del resto de los mosaicos romanos de otras partes del imperio. Las representaciones de Conímbriga y Tarragona constituyen un unicum en el conjunto de la musivaria romana, no porque se representen una sola vez como ocurre con los mosaicos de Esparta y de Thina, sino precisamente por distinguirse del resto del conjunto con el mismo tema. No hay paralelos en mosaicos para estas dos escenas y, lo que es

de sacrificarlas, utilizando asimismo la harpé. El nacimiento de Perseo en una cueva subterránea (ex petra natus) pasó a los misterios mitraicos en un verso de la Tebaida de Estacio: Persei sub rupibus antri indignata sequi torquentem cornua Mithram, entendiendo J.H. Mozley en su comentario a la edición de Loeb que Persei se refiere no al adjetivo «persa» sino a Perseo, con lo que la traducción correcta, según Gómez de Liaño, sería la siguiente: "Mitra retuerce los irritados cuernos (del toro) bajo los riscos de la cueva persea». El simbolismo del antro con la muerte conecta a Perseo con esta idea del mundo subterráneo y de la muerte, a la que irá enfrentándose primero en su infancia y después en sus sucesivas hazañas, para terminar venciéndola definitivamente y alcanzar la inmortalidad convertido en constelación, cf. I. GómEZ DE LIAÑo, El círculo de la sabiduría, Madrid 1998, págs. 115-119: 


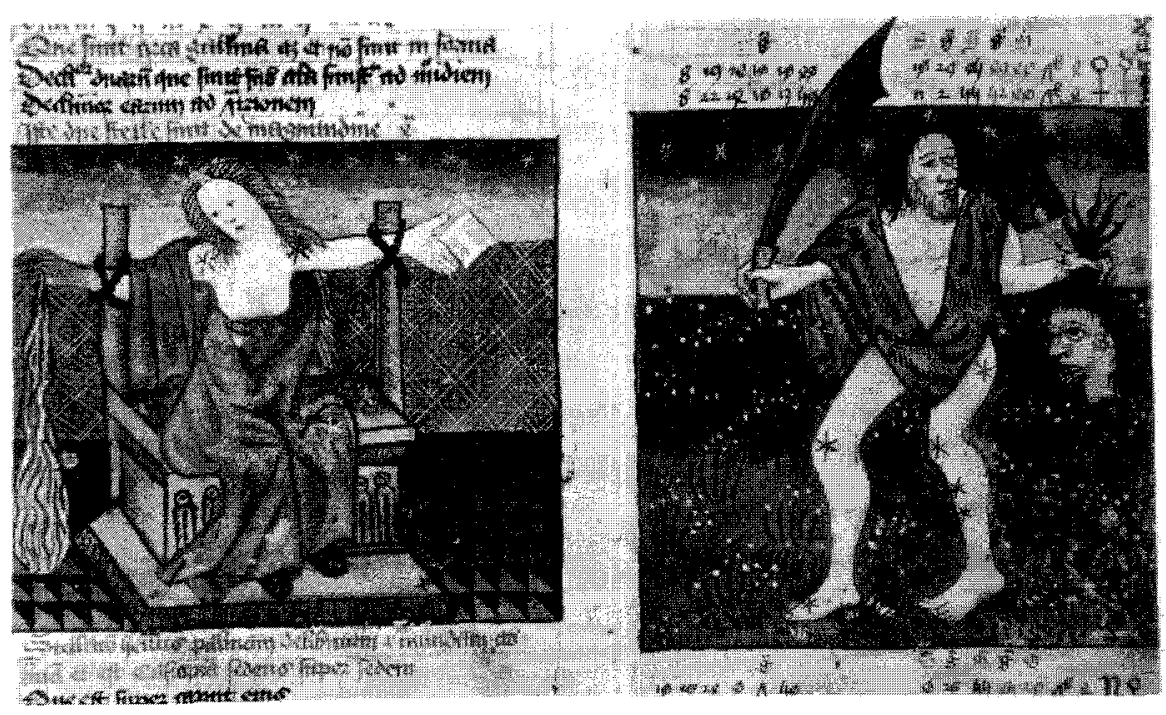

Figura 48. Andrómeda y Perseo representadas como constelaciones. Cod. Arundel 66, fol. $35 \mathrm{v}$.

más notable, en el episodio de la liberación de Andrómeda Perseo no lleva la cabeza de la Medusa, como es habitual.

Quizás una de las peculiaridades más notable del tratamiento del mito de Perseo en la musivaria hispano-romana es su carencia narrativa, Io que no excluye la ausencia del relato mítico. Todo lo contrario, a través de unas reducidas imágenes estáticas - Dánae sentada recibiendo la lluvia de oro que le envía Júpiter desde una nube, Perseo vencedor ya de la medusa y del kethos, Perseo contemplando a Andrómeda después de haber dado muerte al kethos, el gorgoneion- se nos cuenta la totalidad del mito, porque a pesar de su concisión, en ellas están explícitos todos los acontecimientos por su acusado contenido simbólico, que hace innecesaria la imagen narrativa. Así, la musivaria hispano-romana suple la ausencia iconográfica de la decapitación de la Medusa con la representación de dos imágenes que, prescindiendo del carácter narrativo de la acción, sintetizan la hazaña principal del héroe en la figura sola de Perseo con la cabeza de la Medusa en la mano y el kethos a sus pies; y en el gorgoneion en el centro de un "escudo" de triángulos curvilíneos o de escamas bipartitas, símbolo del escudo o de la égida de la diosa Athenea decorada con el trofeo conseguido por Perseo. La acción narrativa de la liberación de Andrómeda se suple con la presencia del kethos a los pies de Perseo, con ausencia de la joven en el caso de Conímbriga y del gesto 
galante del héroe en el de Tarragona. Pero es más, en el mosaicc de Conímbriga, la figura victoriosa de Perseo sobre la medusa y el kethos sintetiza en una sola imagen las dos hazañas del héroe. En este sentido, podría decirse que se trata de escenas globalizadoras en las que todas las imágenes juegan un papel principal y en las que nada se ha dejado al azar.

Seguramente este carácter sintético y alegórico que impregna las escenas musivas hispanas es lo que las diferencia del resto de las representaciones romanas, mucho más narrativas y carentes de contenido, con las que se pretende ilustrar el relato mítico de Perseo a través de imágenes que no implican otra lectura que la simplemente visual, siguiendo especialmente el modelo artístico inventado en época romana. 